\title{
CARTAS DA FRENTE \\ UMA POLÍTICA PÚBLICA NA EXPRESSÃO DOS PROTAGONISTAS DO PROGRAMA FRENTES DE TRABALHO DO GOVERNO DO ESTADO DE SÃO PAULO
}

ROSE MARIE INOJOSA

Tese de Doutorado apresentada ao Departamento de Prática de Saúde da Faculdade de Saúde Pública da Universidade de São Paulo para obtenção do Grau de Doutor em Saúde Pública.

Área de Concentração:Serviços de Saúde Pública

ORIENTADORA PROF ${ }^{a}$ DR ${ }^{a}$ EVELIN NAKED DE CASTRO SÁ

São Paulo - SP

2003

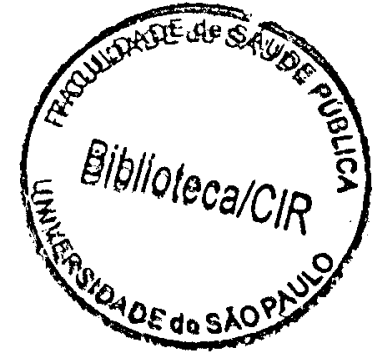


O espaço do sentido não preexiste à leitura e é ao percorrer $e$ cartografar o texto, que o atualizamos, como nos ensina LEVY (1998). Pela leitura ou pela escuta, infiltramo-nos no texto, carregados de nossas bagagens e viajamos na paisagem de palavras semeada de espaços em branco, apanhando fragmentos e relacionando-os com fragmentos de outras viagens $e$, então, reabrimos o texto aos desdobramentos dos sentidos.

Ao elaborar seu discurso e dispará-lo como missiva aos que de algum modo tocaram no curso de suas vidas, os autores das Cartas da Frente, ofereceram generoso manancial de sentidos. Não tenho a pretensão de colhê-los todos e nem o conseguiria se quisesse, pois as possibilidades são emolduradas pelos meus limites. Mas naveguei com prazer nas paisagens descortinadas e sou grata por essa oportunidade.

Este trabalho é dedicado aos autores das Cartas da Frente, aos frentistas, que talvez nunca vejam este texto de suas próprias paisagens recosturado com o fio dos meus sonhos. 
Para Cecília, Beatriz e Luciano, muito amados.

e Evelin, amiga querida. 
INOJOSA, RM. Cartas da Frente uma política pública na expressão dos protagonistas do programa frentes de trabalho do Governo do Estado de São Paulo. São Paulo:2002 (Tese de Doutorado - Faculdade de Saúde Pública da USP).

\section{RESUMO}

Objetivos: Analisar uma política pública, o Programa Emergencial de Auxílio Desemprego - PEAD, conhecido como Frentes de Trabalho, através da visão dos seus beneficiários. verificando a consistência entre a proposta do Programa e os resultados percebidos pelos frentistas e expresso em cartas ao Governador do Estado de São Paulo. Método: Trabalha a manifestação dos frentistas com a metodologia do discurso do sujeito coletivo e compara esse discurso com a proposta contida nos documentos oficiais sobre o Programa e com as cartas-resposta do governo. Resultados: O PEAD focaliza um segmento da população desempregada em situação de desfiliação, utilizando como estratégia o tripé ocupação/renda/qualificação, Segundo os frentistas, a inserção no PEAD foi capaz de provocar uma ruptura na cadeia de perdas que os mantinha na zona de desfiliação $e$ de promover o resgate da sua auto-estima. Não há evidência de sua eficácia para a reinserção do frentista no mercado de trabalho. Considerações Finais: A estratégia do PEAD demonstrou potência para conduzir a população focalizada para a zona de vulnerabilidade assistida. Para evitar seu deslizamento para a situação de desfiliação é necessária a articulação de outros programas de proteção à vida dessa população.

Descritores: Política Pública. Inclusão/Exclusão Social. Desemprego. Frentes de Trabalho. Vocalização. Sujeito Coletivo. 
INOJOSA, RM. Letters from the Work Fronts: a public policy in the words of the protagonists of the Work Fronts Program of São Paulo State Government. São PauloBR:2002 (Doctorate Thesis - Public Health Faculty at USP).

\section{SUMMARY}

Objective: To analyze a public policy, the Unemployement Assistance Emergency Program - PEAD, also know as Work Fronts, from the standpoint of its beneficiaries, verifying the consistency between the Program's proposal and the results perceived by the "frentistas" (recipients), as expressed in their letters addressed to the Governor of São Paulo State. Methodology: It analyzes the "frentistas" feedback using the collective subject speech methodology and compares that speech with the proposal included in the official documents on the Program, as well as with the response letters from the government. Results: PEAD focuses on na unemployed population segment, the employment/income/qualification tripod. According to the "frentistas", their participation into the PEAD Program led to a rupture of the losses sequence that kept them in the disaffiliation zone, and also permitted the rescue of their self-esteem. There are no evidences of the Program's efficacy to allow the reinsertion of the recipients in the work market. Final comments: The PEAD strategy proved its power to move the population under study to a zone of assisted vulnerability. To prevent the "frentistas" to slip into a disaffiliation stage, it is necessary the integration with other Life Protection Programs aimed to that same population.

Descriptors: Public Policy. Social Inclusion/Exclusion, Unemployment. Work Fronts, Vocalization, Collective Subject. 


\section{ÍNDICE}

$\begin{array}{ll}\text { Introdução } & 11\end{array}$

Parte I - O Cenário: Desigualdade e Políticas Públicas 20

Capítulo 1 - Desigualdade e exclusão 21

Capitulo 2 - Politicas públicas e vocalização 32

Capítulo 3 - Proteção social, vocalização e trabalho no Brasil e em São 49

Paulo

Parte II - Objetivos e Metodologia 61

Capítulo 4 - Objetivos $\quad 61$

Capítulo 5 - Metodologia 62

5.1 - O discurso do sujeito coletivo e suas fontes 62

5.2 - O processo de trabalho 70

Parte III - Os personagens e o Programa Emergencial de Auxílio 72

Desemprego - PEAD

Capitulo 6-O perfil do Frentista 73

Capítulo 7 - O Governo do Estado e o PEAD 79

$\begin{array}{ll}7.1 \text { - O que é OPEAD } & 81\end{array}$

7.2 - A população focalizada pelo PEAD 84

7.3 - Objetivos do PEAD 86

7.4 - Estratégias do PEAD $\quad 87$

7.5 - Resultados esperados e obtidos pelo PEAD 90

7.6 - Tipo de organização 91

PARTE IV - Os discursos. $\quad 97$

Capítulo 8-O que diz o frentista 98 
8.1 - A espiral de perdas 99

8.2 - A espiral de ganhos 105

8.3 - A insegurança em relação à curva ascendente 121

Capítulo 9 - O discurso do governo nas cartas-resposta 125

9.1 - O reconhecimento do indivíduo como interlocutor 127

9.2 - A utilização da resposta para dar os créditos do PEAD 130

9.3 - As respostas às solicitações apresentadas 134

Capítulo 10 - Os termos do diálogo 141

PARTE V - Revelações das Cartas da Frente 147

Capítulo 11 - Sobre o frentista como sujeito da avaliação do PEAD 149

11.1 - A apresentação individual e a vocalização do coletivo 149

11.2 - O reconhecimento do discurso 152

Capitulo 12 - Sobre as Frentes de Trabalho como política pública 157

12.1 - A formulação da política 157

12.2 - A avaliação dos frentistas 165

$\begin{array}{ll}\text { Considerações Finais } & 178\end{array}$

$\begin{array}{ll}\text { Referências } & 186\end{array}$

Bibliografia Complementar 195 


\section{ÍNDICE DAS TABELAS, DESENHOS, GRAFICOS E QUADROS}

Tabela 1 : Taxa de Desemprego, segundo Tipo de Desemprego

Região Metropolitana de São Paulo 1985-2000

Tabela 2: Tempo Médio e Mediano Despendido pelos Desempregados

na Procura de Trabalho, segundo Tipo de Desemprego Região

Metropolitana de São Paulo 1985-2000

Gráfico 1: Distribuição mensal das cartas recebidas e respondidas pelo PEAD, no período de janeiro a agosto de 2000

Gráfico 2: Distribuição das cartas segundo autoria frentistas e não frentistas

Gráfico 3: Freqüência das solicitações, por tipo, nas Cartas

Quadro 1: Comparativo do perfil dos frentistas segundo pesquisa realizada em 2000 e segundo o relato das cartas

Quadro 2: Idéias centrais e expressões-chave sobre o que é o PEAD, segundo o discurso do Governo nos documentos oficiais.

Quadro 3: Idéias centrais e expressões-chave sobre a população focalizada pelo PEAD, segundo o discurso do Governo nos documentos oficiais.

Quadro 4: Idéias centrais e expressões-chave sobre os objetivos do PEAD, segundo o discurso do Governo nos documentos oficiais.

Quadro 5: Idéias centrais e expressões-chave sobre as estratégias do PEAD, segundo o discurso do Governo nos documentos oficiais. 
Quadro 6: Idéias centrais e expressões-chave sobre os resultados esperados e obtidos pelo PEAD, segundo o discurso do Governo nos documentos oficiais.

Quadro 7: Idéias centrais e expressões-chave sobre o tipo de 91 organização com que foi implementado o PEAD, segundo o discurso do Governo nos documentos oficiais.

Quadro 8 : Idéias centrais e expressões-chave sobre os elementos 99 deflagradores da espiral de perdas da população do PEAD, segundo as Cartas dos frentistas

Quadro 9:Idéias centrais e expressões-chave sobre os elementos 104 caracterizadores da desfiliação da população do PEAD,segundo as Cartas dos frentistas

Gráfico 4: Distribuição percentual das Cartas da Frente segundo o 106 tipo de benefício relatado

Quadro 10 : Idéias centrais e expressões-chave sobre os ganhos com 107 a inserção no PEAD, segundo as Cartas dos frentistas

Quadro 11 : Idéias centrais e expressões-chave sobre a insegurança quanto ao futuro após o desligamento do PEAD, segundo as Cartas dos frentistas

Quadro 12 : Idéia central e expressões-chave sobre a situação após o 125 desligamento do PEAD, segundo as Cartas dos frentistas

Quadro 13 Idéias centrais e expressões-chave sobre o reconhecimento do frentista como interlocutor, segundo as Cartasresposta do Governo 
Quadro 14 : Idéias centrais e expressões-chave sobre a utilização da

comunicação com o frentista para dar os créditos do PEAD, segundo as Cartas-resposta do Governo

Quadro 15 : Idéias centrais e expressões-chave sobre as respostas às soliciitações apresentadas pelos frentistas, segundo as Cartasresposta do Governo

Quadro 16 : Idéia central e expressões-chave sobre a resposta à solicitação do frentista de continuidade da assistência, segundo as Cartas-resposta do Governo

Gráfico 5: Distribuição das cartas dos frentistas segundo o 142 endereçamento

Desenho 1: Componentes da espiral de perdas, iniciada com 0 desemprego e da espiral de ganhos, iniciada pela inserção na Frente de Trabalho, segundo as Cartas da Frente

Quadro 17 : Principais problemas, por Secretaria, segundo levantamento realizado no início do Governo Mário Covas

Desenho 2: Ilustração sobre a relação entre a espiral de perdas e 163 ganhos e as zonas que caracterizam o gradiente entre a situação de integração e a situação de desfiliação social

Desenho 3: Ilustrativo do tripé em que se assenta a estratégia de implementação do PEAD 


\section{INTRODUÇÃO}

"Querido Governador" (70)

"Por favor gostaria de merecer um pouco de sua atenção, quem the escreve é uma das participantes da frente de trabalho. (25)

Antes de vocês criarem esta frente de trabalho, eu estava desempregada e quando vocês a criaram, ela foi à solução dos meus problemas, agora posso comprar o que eu preciso, não tudo, mas o importante.(91)

"Fiquei muito feliz quando vi meu nome na lista dos selecionados. Sou arrimo de familia, tenho 5 filhos e sou separada. Vivo da ajuda de familiares, mas agora que trabalho pela frente aliviou um pouco a barra. Há dez anos que enfrento os obstáculos da vida, pois o meu marido se encontra em uma cadeira de rodas devido a um tiro que levou na coluna. Portanto ele não pode dar pensão alimentícia para as crianças."(37)

"Na minha casa eu não tenho nem uma cama para dormir. Eu durmo no colchão no chão, moro no barraco que nem cimento tem no chão."(241)

\footnotetext{
${ }^{1}$ Esta carta foi construída com trechos de cartas de frentistas que constituiram o universo da pesquisa e que são apresentadas na integra no Anexo. $O$ número entre parênteses no final de cada frase identifica a carta de origem:
} 
"Estou muito contente porque antes eu e meus filhos passávamos muita necessidade, mas depois que comecei a trabalhar na frente nunca mais faltou comida e nem material escolar para os meus filhos."(64)

"Eu trabalho no posto da V.A,, zona leste, e sinto que os meus serviços são bem vistos e bem vindos aqui. Sinto também que sou importante aqui, pois a limpeza que fazemos todos gostam.(175) "(...)gosto muito do que faço, adoro dividir a minha alegria com as minhas colegas de trabalho.(197)

Além do mais estou fazendo curso de cabeleireira, estou adorando a oportunidade, pois não tive condições de comprar o material para fazer estes cursos pelo $C$. e agora estou fazendo - curso pela frente de trabalho e sem precisar comprar o material, eles fornecem o material para que nós aprendamos. (...)(196)

"(...) O senhor nunca me viu, não sabe quem sou eu, mas deu uma coisa que eu acho que todo o ser humano quer dignidade e cidadania. Sabe porque eu digo tudo isto? Porque eu já senti o que é chegar ao fundo do poço. Não ter esperança no amanhã, sentir-se um joão ninguém., Uma pessoa a mais na multidão dos excluídos." (324) "Atualmente me sinto um ser útil à sociedade." (76)

"Trabalhei os nove meses (...), ganhei durante este período os 150,00 e a cesta básica, também estou terminando o 
meu curso,(...) foi ótimo, aprendemos muita coisa boa, além da profissão que escolhi, aprendemos aulas de cidadania, saúde, meio-ambiente, globalização, etc. Foi muito bom, só que tudo isso acabou, principalmente para mim que já tenho esta idade e que todas as portas se fecham (...) o senhor nem sabe como tudo isso é difícil.(...) 239

"Senhor eu não sei o que vai acontecer quando eu voltar a ficar sem emprego no término dos nove meses. Sou ciente do nosso contrato, mas ele é tudo que eu tenho para viver materialmente falando. (178) "(...) Só Deus sabe o que pode acontecer com cada um de nós, pois está difícil demais conseguir empregos."(328)

"Gostaria de pedir a vocês que efetivassem essas pessoas no emprego, pois é tão pouco tempo e todos nós ficaremos todos desempregados e voltaremos à mesma situação ruim. "(350)

"Obrigada pela oportunidade que me deu para desabafar."(54)

"Por favor, se for possivel, mande-me uma resposta que eu estarei aguardando."(345) "(...)Fico aguardando resposta do senhor com o coração na mão, que Deus o abençoe por tudo." (347)

"Abraço da sua bolsista Maria....." (306) 
"Prezada Senhora Maria ${ }^{2}$

É com prazer que o Governador Mário Covas recebe a sua carta relatando sua participação no Programa Emergencial de Auxilio-Desemprego - PEAD. É importante para nós que os participantes das Frentes de Trabalho digam sua opinião sobre - programa, pois só assim o Governador juntamente com o Secretário do Emprego e Relações do Trabalho Walter Barelli podem cada vez mais colaborar para a solução do problema do desemprego no Estado de São Paulo.

Quanto ao seu pedido para permanecer nas Frentes de Trabalho informamos que, de acordo com o Decreto que regulamenta o PEAD, a permanência dos bolsistas no referido programa não pode ultrapassar 9 meses. $O$ esforço do nosso governador, através do Secretário Walter Barelli, em oferecer oportunidade àqueles inscritos no PEAD tem sido contínuo. Porém em virtude do número de inscritos ultrapassar a quantidade de vagas disponíveis, há pessoas que não estão participando das Frentes de Trabalho. Ainda há 330 mil pessoas aguardando uma convocação.

${ }^{2}$ Esta carta foi construida com trechos das cartas-resposta do Governo aos frentistas. assinadas pelo Coordenador do PEAD. 
Orientamos que a senhora procure o Posto de Atendimento ao Trabalhador - PAT - da rua Tadeu Fontana, n¹11, ou consultá-los pelo fone 23242422.

Esperamos que, com os conhecimentos adquiridos no Curso de Qualificação, a senhora possa ser absorvida pelo mercado de trabalho.

Outra possibilidade é pensar em uma cooperativa, para o que the foi oferecido durante o curso de qualificação informações sobre o assunto. Entretanto, a senhora pode procurar o Programa de Auto-Emprego, sito à Av. Angélica, 2582.

\section{Atenciosamente}

\section{ILSO TAMELINI}

Coordenador do Programa Emergencial de Auxílio Desemprego"

Esse diálogo entre cidadão e governo constitui o foco deste trabalho, que se iniciou com um fio de sonhos que emaranhei nas Cartas da Frente, pois todo texto é um objeto virtual capaz de múltiplas atualizações, onde cada leitor deposita outros discursos, imagens, afetos, projetos, o fio dos seus sonhos (LEVY 1998). 
Quando nos relacionamos com um texto, começamos a tecer uma trama que mistura o que ali podemos encontrar com fios que trazemos de outras paragens e intenções.

Ao pretender a análise de um discurso, está implícito que o texto será revirado, "dobrado sobre si mesmo", enquanto apreendemos e construímos uma paisagem com seus fragmentos e com fragmentos de outras paisagens e, então, recosturamos o texto "para abrir um meio vivo no qual possa se desdobrar o sentido." (LEVY 1998, p.36).

E se, além disso, o projeto é gerar um novo texto que se apresente como discurso de um sujeito coletivo, como "uma forma de expressar diretamente a representação social de um dado sujeito, plural e uno" (SÁ e IBANHES 2000, p.125), é preciso anunciar que esse discurso resulta de uma viagem que é realizada por outro sujeito e que é impossivel e indesejável ocultar o fio que costura os fragmentos das paisagens encontradas. Ao contrário, é preciso dizer-se de que material é feito e como foi tecido.

Este trabalho começou em 1999, quando cartas escritas por participantes do PEAD - Programa Emergencial de Auxilio Desemprego, me encontraram pelas mãos da Vanya Mundin Sant Anna, que dirigia a área de Gestão de Políticas Sociais na FUNDAP - Fundação do Desenvolvimento Administrativo ${ }^{3}$.

\footnotetext{
${ }^{3}$ A FUNDAP prestou assessoria à Secretaria do Emprego e das Relações do Trabalho para a implantação do PEAD - Programa Emergencial de Auxílio Desemprego, coordenado pelo Sr. Ilso Tamelini, desde o seu inicio, com uma equipe coordenada por Hadjimu Miyashita e composta por Sandra Inês Baraglio Granja, Ana Lúcia Magyar. José Lucas Cordeiro e Maria Helena de Castro Lima.
} 
As cartas dos frentistas ${ }^{4}$ trazem informações oferecidas pelos próprios protagonistas do Programa Emergencial de Auxilio Desemprego, sobre sua vida e a sua percepção sobre o que mudou ou não mudou em função do PEAD. Contam, agradecem, fazem solicitações, pedem resposta. Fiz a primeira leitura das cartas em uma noite, como se estivesse escutando as falas dos frentistas. Sua linguagem, os episódios de suas vidas que são contados, os agradecimentos e solicitações, no mais das vezes, ao próprio Governador, descortinaram todo um universo de sentidos, sugeriram uma pertença recíproca e soaram como um discurso coletivo. Assim foi porque encontrei ali a voz do homem simples, posto a margem da história, da possibilidade de tornar-se agente ativo de seu destino. Porém, " a história irrompe na vida de todo dia e trava aí o limite a que se propõe, o de realizar no tempo miúdo da vida cotidiana as conquistas fundamentais do gênero humano, aquilo que liberta o homem das múltiplas misérias que o fazem pobre de tudo: de condições adequadas de vida, de tempo para si e para os seus, de liberdade, de imaginação, de prazer no trabalho, de criatividade, de alegria e de festa, de compreensão ativa de seu lugar na construção social da realidade." (MARTINS 2000, p.12)

A partir daí, com a orientação paciente da Professora Evelin Naked de Castro Sá, busquei o instrumental para reler as primeiras cartas e fazer a leitura de outras tantas a que tive acesso através do Dr. Ilso Tamelini,

\footnotetext{
${ }^{4}$ Utiliza-se a denominação frentista com o intuído de salientar a participação em Frentes de Trabalho, embora o governo chame os participantes de bolsistas, denominação comum aos vários programas que prevêem bolsas.
} 
Coordenador do Programa, que também autorizou o acesso às cartasresposta aos frentistas.

O material que constituiu o universo da pesquisa foi trabalhado, com metodologia do discurso do sujeito coletivo, de modo a elaborar esse discurso, ou melhor, de reconstruir o discurso que espontaneamente se havia formulado no nosso primeiro encontro, como uma voz coletiva e não apenas manifestações individuais singulares, $E$, também, para verificar como interagem o discurso dos frentistas e o discurso do governo sobre o mesmo Programa.

O discurso do governo não se apresenta disperso em manifestações de diferentes individuos, como é o caso do discurso dos frentistas. Ao contrário, existe um discurso oficial, onde o sujeito é o Governo e os indivíduos estão ocultos ou o representam. Esse discurso revelou-se através de duas fontes: os documentos legais de constituição do Programa e as cartas-resposta aos frentistas.

Por que tanto quero compartilhar esses discursos dos protagonistas do PEAD e apresentá-los a outras pessoas? Penso que eles podem ajudar, de algum modo, a iluminar a discussão sobre as possibilidades das políticas sociais, seu caráter transformador ou compensatório.

Com a esperança de provocar esse interesse $e$, talvez, inserir na trama da compreensão o fio de outros sonhos, é que abri esse trabalho com a própria apresentação do diálogo entre os frentistas e o governo, através dos dois discursos desses sujeitos expressos em formato de cartas, por mim construídas. 
A partir daqui o trabalho é subdividido nas seguintes Partes.

A Parte I trata do cenário onde se configura a situação dos protagonistas do PEAD, no bojo das condições geradas pelo capitalismo contemporâneo, da dialética inclusão/exclusão, das intervenções do Estado e da capacidade de vocalização da população. No desenvolvimento desta parte é apresentado o referencial teórico que ampara este trabalho.

Na Parte II são apresentados os objetivos e a metodologia da pesquisa.

A PARTE III é dedicada aos protagonistas, buscando caracterizar o perfil dos falantes. Apresenta a caracterização do frentista, enquanto população focalizada pelo PEAD e, através do discurso oficial, o Governo que formulou e implementou o programa.

Os discursos são apresentados na Parte IV, com a reconstrução do caminho metodológico percorrido para chegar até produção do discurso do frentista como sujeito coletivo e também na análise da manifestação do Governo, através das cartas-resposta aos frentistas.

Na Parte $V$ as revelações da pesquisa com as Cartas da Frente são trabalhadas de dois pontos de vista:

- ofrentista como sujeito e

- a consistência entre a proposta do PEAD e os resultados percebidos por esse sujeito, tal como revela em seu discurso 
Nas Considerações Finais são comentados aspectos do que essas vozes podem sugerir para os formuladores de políticas públicas e gestores sociais que estejam utilizando ou pretendam utilizar o modelo Frentes de Trabalho.

\section{PARTE I}

\section{O CENÁRIO: DESIGUALDADE E POLÍTICAS PÚBLICAS}

Esta Parte trata de delinear o cenário e a situação onde se inserem os frentistas e o Programa Emergencial de Auxílio Desemprego, explicitando o referencial teórico que é utilizado nesse delineamento e que orienta a análise do material da pesquisa com as Cartas da Frente.

No capítulo 1 são trabalhados a questão da produção da desigualdade no modelo capitalista e o movimento dialético de inserção/exclusão que resulta desse modelo. As análises são amparadas principalmente em DEMO (1995, 1998), DOWBOR (2001 e 2002) e KLIKSBERG $(1997,2002)$ no que diz respeito ao processo do capitalismo e a produção da desigualdade; e em CASTEL $(1991,2000)$ e PAUGAM (1999) para a questão da dialética inclusão/exclusão.

O capítulo 2 é dedicado ao processo de formulação das políticas públicas e a gestão social, ainda com os autores que informaram o primeiro capítulo, bem como à questão da capacidade de vocalização enquanto inserção de necessidades e demandas da Sociedade nas políticas e na gestão social. Ampara-se em OFFE (1984) a análise da relação entre vocalização e formulação das políticas. Para a questão participação/vocalização e gestão 
social, são referências as idéias de OFFE (1984), TOURAINE (1999) e MARTINS (1994) e a análise de DOIMO (1997).

Finalmente, como essas dimensões podem ser observadas no Brasil e em São Paulo, onde estão os protagonistas das Cartas da Frente, é objeto do capítulo 3.

\section{Capítulo 1 - Desigualdade e exclusão}

A desigualdade está, como sempre esteve, no cerne do movimento de inclusão/exclusão social, pois é inerente à lógica do capitalismo.

Durante as primeiras fases do capitalismo nos países centrais - na Europa - a pobreza foi tratada apenas de modo assistencial. Nos Estados Unidos da América o capitalismo, permeado pela lógica calvinista, sempre tratou a pobreza sob a ótica do mercado, buscando mecanismos de reinserir os pobres no mercado de trabalho e/ou no mercado consumidor.

Essa perspectiva assistencial foi reeditada nos países periféricos, embora neles os resultados da desigualdade tenham sido freqüentemente mais dramáticos, pois o chamado Terceiro Mundo sempre teve parte importante de sua população mergulhada em uma situação de pobreza extrema.

Com a evolução da discussão dos direitos humanos e de cidadania nos países centrais e com o capitalismo avançando para uma fase em que a produção industrial já substituía parte importante da força de trabalho por 
novas soluções tecnológicas, os governos daqueles paises depararam-se com a necessidade de dar respostas às conseqüências sociais da pobreza.

Mudanças do sistema produtivo geraram a degradação do emprego e a pobreza deixou de ser residual, mesmo nos paises centrais.

A desigualdade foi extremamente aprofundada na fase atual do capitalismo globalizado. Nas últimas três décadas a concentração de renda aumentou exponencialmente no planeta, desequilibrando radicalmente a relação entre lucros e salários, sendo que os lucros não são direcionados para investimentos no mundo da produção mas para atividades de intermediação especulativa. Daí resulta mais injustiça econômica e mais estagnação. Esse binômio se revela no decréscimo progressivo da taxa de crescimento da economia do planeta que, na década de 70, apresentava uma média geral de $4 \%$, tendo caído para $3 \%$ nos anos 80 e $2 \%$ na década de 90 . (DOWBOR 2001, p.19)

O capitalismo contemporâneo permite que a riqueza cresça sem crescer - ou até mesmo reduzindo - a inserção de pessoas no sistema produtivo. Esse sistema gera desemprego, dilapida o meio ambiente e remunera mais os especuladores do que os produtores. ${ }^{5}$. Com isso a riqueza se acumula em poucas mãos e cresce a população que não tem como auferir

${ }^{5}$ Citando um balanço do jornal Le Monde Diplomatique, de novembro de 1998, DOWBOR (2001, p.19) mostra que no primeiro semestre daquele ano (1998), a Peugeot, com 140 mil funcionários conseguiu um lucro de 330 milhões de dólares e o Citybank, no primeiro semestre de 1997, com 320 operadores do setor de negociação de divisas alcançou um lucro de 500 milhões de dólares. 
renda pelo emprego ou pelo trabalho e que, portanto, fica à margem do mercado consumidor (DEMO 1998)

Citando Relatório do PNUD, KLIKSBERG (2002, p.16) nos lembra de que, nos últimos 30 anos o volume da renda de $20 \%$ das pessoas mais pobres do mundo caiu de 2 para 1,48 da renda mundial. A posição dos $20 \%$ mais ricos passou de 70 para $85 \%$ da riqueza mundial.

Se nas fases anteriores do capitalismo atribuía-se a culpa da exclusão ao excluido, pela sua incapacidade de inserir-se no mercado de trabalho $e$, portanto, no mercado consumidor, nesta fase do capitalismo global, o mesmo raciocínio tende a aplicar-se não só às pessoas mas aos países periféricos, que não capacitam suficientemente sua força de trabalho, não combatem a corrupção, não seguem receitas que lhes são ditadas pelo Fundo Monetário Internacional, etc. e que, por sua responsabilidade, não conseguem inserir-se no mercado global, como se o risco da exclusão não fosse desigualmente repartido, tanto entre os cidadãos como entre os paises.

O raciocínio é falacioso porque o novo desemprego não surge da falta de crescimento, mas do próprio crescimento.

Além da substituição de importante parte da mão de obra humana por tecnologia na produção de bens e serviços nas empresas tradicionais, surgiram "as holdings financeiras de diversos tipos, que só lidam com 'intangiveis' , com gestão, promoção, organização, deixando a produção para empresas subcontratadas." (DOWBOR 2002, p.14) Esse movimento precarizou as relações de emprego, pois o trabalhador aceita a informalidade para preservar a possibilidade de auferir algum rendimento em troca de trabalho. 
KLIKSBERG (2002) cita o World Employment Report da OIT que mostra, em 1995, 30\% de toda a mão-de-obra do mundo desempregada ou subempregada, com uma contínua transferência de pessoas para a chamada economia informal, constituida de trabalhos instáveis, sem perspectivas claras, sem proteção social de nenhuma espécie, com baixas rendas e com niveis de produtividade muito inferiores aos da economia formal, devido às limitações de recursos,

Criticando os franceses da "nova questão social", porque não se trata de uma nova questão e porque não teriam avançado na discussão teórica, Demo (1998) insiste para que não nos esqueçamos de que na raiz da exclusão está a desigualdade, "filha dileta do capitalismo". Para ele, no alargamento da pobreza, "o desconforto histórico é mais forte que a novidade teórica" (DEMO 1998, p.40)

Apesar da crítica ao fato de que as propostas que não avançam no sentido de confrontar "o velho escândalo capitalista" (DEMO 1998, p.38), os franceses, premidos pelo desemprego no início da década de 90 , deram visibilidade ao problema e consideraram o fenômeno com olhos novos. Porque a magnitude da questão é nova e não aceita o mesmo remédio que o capitalismo reservou à pobreza residual nos países centrais.

Já não há como ignorar as consequiências da pobreza do Terceiro Mundo, pois a desigualdade intrínseca ao modelo capitalista manifesta-se escancaradamente entre países e blocos mundiais. A face mais visível do drama planetário configurado pela desigualdade é a exclusão social - filha primogênita da desigualdade. 
Muitos autores desautorizam o uso da expressão exclusão social. Para - sociólogo José de Souza Martins ela serve de disfarce para as formas anômalas e injustas de inclusão, "que decorrem de um modelo de reprodução ampliada do capital, que, no limite, produz escravidão, desenraizamentos, pobreza e também ilusões de inserção social" 6

Concordo com a restrição à expressão quando utilizada para designar simplesmente um estado. Exclusão social não é um estado, mas um processo múltiplo, complexo e contraditório. Processo que se explica por várias situações de privação da autonomia, do desenvolvimento humano, da qualidade de vida, da equidade e da igualdade (SPOSATI 1996) e que se apresenta como uma "dialética exclusão/inclusão", pois só existe em relação à inclusão, como parte constitutiva dela (SAWAIA 1999)

A exclusão nasce da repartição desigual da riqueza na sociedade, inerente ao capitalismo. Sua configuração é um processo multicausado "uma espécie de engrenagem de perdas, em uma espiral" (PAUGAM 1999, p.55), que não pode ser caracterizada simplesmente como uma situação de miséria econômica.

A espiral de perdas que se verifica na vida dos individuos e grupos ao longo do tempo e que vai significando um acréscimo progressivo de dificuldades, manifesta-se claramente na fragilização ou afrouxamento dos vínculos sociais de grupos que acumulam desvantagens nas diferentes esferas da vida coletiva - o trabalho, a família, a vizinhança, a escola ameaçando os indivíduos com a perda de seu lugar na sociedade, com um

\footnotetext{
${ }^{6}$ Entrevista de José de Souza Martins para Caio Caramico Soares, Exclusão fora de foco, publicado no Caderno Mais 553, Folha de S.Paulo, edição de 15 de setembro de 2002. pg.3.
} 
isolamento duradouro $A$ expulsão do mundo do trabalho é uma dimensão crítica dessa dialética inclusão/exclusão, pois gera perda de autonomia, da possibilidade de auto provimento de condições básicas de vida e promove o rompimento de outros laços da rede social de cada pessoa - família, amizades, relações comunitárias - ampliando as vulnerabilidades $e \quad 0$ isolamento de cada indivíduo e do grupo social. "A exclusão é inicialmente uma ausência durável de emprego, mas é igualmente uma perda de relações " (DEMO 1998, p.111)

É de PAUGAM (1999) a imagem da exclusão como uma espiral de perdas. Essa espiral poderia ser vista como um movimento que se dá em zonas ou patamares. Ele identifica três patamares da pobreza: integrada, marginal e desqualificante.

A pobreza chamada por PAUGAM de integrada é a pobreza residual que foi objeto privilegiado do Welfare State. Caracteriza-se por um nivel de vida com acesso restrito a bens e serviços mas onde o individuo fortemente integrado em seus espaços sociais, organizados em torno da família e do bairro ou da vila (PAUGAM 1999). A manutenção da rede social equilibra o afastamento do mercado.

O segundo nível é a denominada pobreza marginal. Está entre a pobreza integrada e a exclusão. Caracteriza-se pela fragilização da rede social (PAUGAM 1999)

Finalmente, a pobreza desqualificante, onde há maior alijamento da esfera produtiva e maior dependência das instituições (PAUGAM, 1999). A desqualificação social "caracteriza o movimento de expulsão gradativa, para 
fora do mercado de trabalho, de camadas cada vez mais numerosas da população - $e$ as experiências vividas na relação de assistência, ocorridas durante as diferentes fases desse processo." (PAUGAM 1999, p.67)

Vinculada ao movimento do capitalismo contemporâneo, a expulsão do mundo do trabalho é considerada uma dimensão crítica da dialética inclusão/exclusão, pois gera perda de autonomia, da possibilidade de autoprovimento de condições básicas de vida e promove o rompimento de outros laços da rede social de cada pessoa - família, amizades, relações comunitárias - ampliando as vulnerabilidades de cada indivíduo e do grupo social.

A idéia de uma espiral - de perdas e ganhos dependendo do sentido parece uma boa imagem para compreender o movimento dialético inclusão/exclusão. Assim, muitas vezes a expulsão do mundo do trabalho dá origem ao movimento em espiral de perdas, ao acúmulo de desvantagens (handcaps) que leva ao afrouxamento dos vínculos sociais do indivíduo e à conseqüente ameaça de perder o lugar que ocupa na sociedade.(PAUGAM 1999. p.50/51)

Configura-se, com isso, uma situação de risco para o bem estar dos individuos e da própria sociedade, que sinalizam, com sintomas, o seu processo de adoecimento ${ }^{7}$.

\footnotetext{
${ }^{7} O$ perfil de saúde-doença de uma sociedade dialoga com o seu perfil de reprodução social. caracterizado pelas "formas de trabalhar e consumir, pelas relações que os seres humanos estabelecem entre si para produzir a vida social, pela forma em que transformam a natureza, pela forma em que realizam a distribuição $e o$ intercâmbio dos bens socialmente produzidos, pelas instituições que geram e pelo nivel de consciência e organização que
} 
Olhando para a sociedade, "a exclusão contemporânea é diferente das formas existentes anteriormente de discriminação ou mesmo de segregação, uma vez que tende a criar, internacionalmente, indivíduos inteiramente desnecessários ao universo produtivo, para os quais parece não haver mais possibilidades de inserção. Poder-se-ia dizer que os novos excluídos são seres descartáveis." (WANDERLEY 1999, p.25)

KLIKSBERG identifica uma degradação da qualidade da pobreza, com o aumento da pobreza extrema, isto é, "das famílias que ainda que gastassem toda a sua renda exclusivamente na compra de alimentos não conseguiriam comprar proteínas e calorias na quantidade mínima necessária á sobrevivência." (KLIKSBERG 1997, p.19) Essa pobreza é discriminatória, atinge principalmente as mulheres e as crianças, como o mesmo autor mostra fartamente em dados referentes à pobreza na América Latina. Segundo os estudos existentes, cresceu a proporção de famílias sustentadas por mulheres e essas familias apresentam os maiores índices de pobreza, pois às condições sociais desfavoráveis somam-se as discriminações culturais.

Em conseqüência das mudanças no mundo da produção, entre 1980 e 1992, o emprego no setor moderno da economia diminuiu constantemente, degradou-se a qualidade dos empregos, com o crescimento do emprego informal, da precariedade das relações de trabalho e da redução de rendimentos. Além de aumentarem as taxas de desemprego, também se elevou o periodo médio de duração do desemprego. (KLIKSBERG 1997, p.20-

alcançam." (CAMPAÑA 1997, p.133). Como afirmam PAIM E ALMEIDA FILHO (1998) "nada que se refira à saúde do público, por conseguinte, será estranho à saúde coletiva." 
21). Nesse contexto, surgiram os "novos pobres" , contingentes crescentes de setores das classes médias em decadência, pela falta de empregos ou pela erosão das relações de trabalho. KLIKSBERG (1997, p.23) ressalta o sentimento de "desenraizamento social" provocado na classe média e aponta a queda da auto-estima.

Outra característica desse movimento geral de empobrecimento é o enfraquecimento da família, influenciado pelas demais circunstâncias e que é particularmente importante nos setores mais pobres da população. Por que crescem as unidades chefiadas por um só cônjuge? Por que se produz o abandono? KLIKSBERG (1997, p.33) cita estudo de Ruben KATZMAN, de 1992, que aponta a dificuldade do homem em desempenhar o papel de provedor historicamente atribuido e de lidar com a pressão familiar pelo consumo. Por outro lado, a mulher assume a chefia da família e passa a concentrar-se no provimento das necessidades básicas, ausentando-se do convivio dos filhos. Estes perdem os modelos de referência. A anomia familiar prejudica o desenvolvimento biológico, intelectual e afetivo das crianças e dificulta a transmissão intergeracional de valores necessários para estabelecer regras de convivência social e prevenir condutas conflituosas.

CASTEL (1991) trabalha com essa conjunção de vetores: integração/não integração pelo trabalho $e$ inserção/não inserção em uma sociabilidade sócio familiar, como duas faces da mesma condição. Segundo este modelo, as populações suscetíveis de destacar intervenções sociais estão ameaçadas pela insuficiência de seus recursos materiais e também 
fragilizadas pela labilidade de seu tecido relacional; estão não apenas em vias de pauperização mas também em processo de desfiliação, ou seja, em ruptura de vínculo com o social (CASTEL 2000).

Ao final do processo, "a precariedade econômica torna-se privação, a fragilidade relacional isolamento" (CASTEL 1991, p.23). Esse autor distingue zonas diferentes do espaço social, conforme o grau de coesão que elas asseguram: integração; vulnerabilidade; assistência e desfiliação (CASTEL 1991, p.30-31). As fronteiras dessas zonas são porosas, cruzariam horizontalmente e de maneira flexivel a espiral de perdas e ganhos, imagem que estamos utilizando para o processo de inclusão/exclusão,

Combinando sempre os dois eixos - trabalho e relação - na zona de integração as pessoas disporiam de garantias de trabalho permanente $e$ capacidade de mobilizar suportes relacionais sólidos. A zona de wilnerabilidade associa precariedade do trabalho e fragilidade relacional e a zona de desfiliação conjuga ausência de trabalho e isolamento social. A zona de vulnerabilidade alimenta a zona de desfiliação.

A zona de assistência, acrescentada posteriormente por CASTEL, se caracterizaria por uma dependência 'segurada e integrada', com forte componente de coesão social. Difere, ao mesmo tempo, da zona de integração autônoma pelo trabalho e da zona de exclusão pelo não trabalho e pela não -inserção (CASTEL 1991, p.31). A zona de assistência existe na medida da mobilização da sociedade para resguardar a coesão social, garantindo uma inserção dependente. 
Aparentemente, a zona assistencial teria sido delineada para a pobreza tradicional residual, na medida em que não gera autonomia, é um esquema de dependência.

PAUGAM (1999, p.73), que também trabalha com os dois eixos trabalho e relação social - considera que a vulnerabilidade (ou fragilidade) $e$ a dependência constituem fases da desqualificação social.

Os desempregados, diz PAUGAM (1999), "têm invariavelmente relações mais distantes com os membros de sua família: quanto mais precária for a situação no mercado de trabalho, maior é a possibilidade de o indivíduo não ter nenhuma relação com a família". Além disso, "quanto maior é a precariedade profissional, menor é a possibilidade do indivíduo auferir ajuda do seu meio social." (PAUGAM 1999, p.72).

Fragilizados na sua capacidade de auto-provimento, os desempregados precisam valer-se dos serviços sociais para alcançar bens e serviços essenciais à sobrevivência.

Os serviços sociais foram delineados para atender a pobreza residual, no modelo conservador. Diferentemente da situação nos países centrais, como a França, que é o lugar de onde fala PAUGAM, os serviços sociais dos países periféricos não dispõem de recursos para prover essas bens $e$ serviços essenciais de forma equânime. Se já havia crise nos anos 80 , 0 aumento de demanda dos anos 90 , sem uma estratégia redistributiva, trouxe mais dificuldades no atendimento. Desse modo, o exercício da dependência dos serviços sociais acrescentaria ao indivíduo ou à família novas 
experiências humilhantes, aprofundando a perda da auto-estima e a ruptura de vínculos.

"Na realidade, os pobres não participam da vida econômica, nem da social, nem da política. Estão excluídos do mercado, e sua presença política ou influência social mantêm-se mais no plano formal do que no real. $\mathrm{Na}$ realidade, ao excluir os pobres da economia e da sociedade, nega-se-Ihes o direito de lutar para livrarem-se da pobreza" (PNUD 1995)

A espiral de perdas se manifesta em situações de privação da autonomia e de oportunidades de desenvolvimento, de sofrimento humanos, da falta de equidade, da injustiça, gera uma situação de negação da saúde. Esse processo que torna doentes individuos e grupos mais vulneráveis faz adoecer a própria sociedade. Nessa dimensão, exclusão pode ser entendida "como descompromisso político com o sofrimento do outro" (SAWAIA 1999, p.8)

Pelo compromisso político com o sofrimento é que, na arena de interesses contraditórios onde as demandas da sociedade se apresentam ao Estado, os grupos capazes de vocalização inscrevem na agenda governamental a necessidade de atenção aos indivíduos e segmentos da população cujos laços sociais se esgarçam no processo de exclusão.

\section{Capítulo 2 - Políticas públicas e vocalização}

O caráter das políticas públicas e o foco da gestão social têm relação com o papel que a Sociedade atribui ou reconhece ao Estado em cada 
momento histórico. O Estado não pode ser melhor do que a cidadania que o sustenta (DEMO 1998, p.4)

O Estado capitalista reflete a dinâmica contraditória das classes sociais $e$ das alianças de grupos de interesses, que são conflitantes $e$ mudam segundo o contexto, assim o "Estado que tem de exercer funções contraditórias, de acumulação e de legitimação, para criar as bases de um consenso através da ação de suas instituições." (JACOBI 1989,p.4)

O Welfare State - Estado de Bem Estar - nasceu como política pública nos paises centrais, deu conta de trabalhar com uma pobreza residual e por isso mesmo tratável, na própria perspectiva do capitalismo, como analisa DEMO (1998).

Dois modelos de Estado de Bem Estar prosperaram. $O$ modelo bismarquiano, conservador, desenvolvido pelos alemães e pelos franceses e 0 modelo universalista, de cariz escandinavo. ${ }^{8}$

O modelo conservador considera que os ativos devam pagar pelos inativos, os sadios pelos doentes, supondo que as despesas sejam cobertas basicamente pela contribuição dos ativos e dos sadios. Esse modelo não é propriamente redistributivo, porque parte do acesso a benefícios está

${ }^{8}$ VIANA (1997) detalha o Estado do Bem-Estar em 4 tipos:

- universal, definindo-se pela modalidade seguridade, para o fornecimento da assistência pensionistica e sanitária (Escandinávia)

- ocupacional, caracterizando-se pela prevalência da forma seguro na assistência pensionistica e sanitária (Europa continental)

- universal misto, usando as modalidades seguridade e seguro (Inglaterra, Nova Zelândia e Canadá)

- ocupacional misto, usando as modalidades seguro e seguridade (Itália, Suiça, Holanda e Irlanda) 
vinculado a contribuições anteriores. Os indivíduos contribuem enquanto ativos e sadios para bancar sua inatividade ou doença Isso significa que a ajuda social é complementar ou residual.

O modelo universalista, por sua vez, trabalha com o princípio da solidariedade. Seu fundamento básico não é a seguridade e sim um conjunto de direitos ou condições a que todos os cidadãos deveriam ter acesso. Recursos da sociedade são mobilizados para garantir que os cidadãos, contribuintes ou não, tenham acesso a bens e serviços inscritos como direito de todos, como a educação fundamental e a saúde, por exemplo.

No século XX, ao mesmo tempo em que se aprofundou a desigualdade social, como consequiência do estágio global do capitalismo, os direitos de cidadania passaram a apresentar-se como fundamento das políticas públicas, - que foi uma conquista da civilização.

Em tese, são as necessidades e demandas dos cidadãos, na perspectiva dos direitos de cidadania, que constituem o foco da gestão social, compreendida como gestão das ações sociais públicas, (CARVALHO 1999, p.19).

Entretanto, com as mudanças do sistema produtivo a pobreza deixou de ser residual, mesmo nos paises centrais, pressionando extraordinariamente as políticas de Bem-Estar assentadas na lógica do capitalismo. Nos paises periféricos, apenas alguns mecanismos do Welfare State chegaram a ser implementados. 
No caso dos paises periféricos, a intervenção do Estado tem sido determinante no setor de infra-estrutura, essencial para inserir o pais na divisão internacional do trabalho, na medida em que provê condições para a reprodução e expansão do capital privado. Porém, sua intervenção é menor no aspecto regulamentador e na reprodução da força de trabalho, o que se manifesta na baixa apropriação de serviços públicos essenciais.

As políticas sociais têm sido caudatárias da política econômica. KLIKSBERG cita a frase atribuída a um ministro da Economia da América Latina de que "a única política social é a política econômica" (KLIKSBERG 2001, p.29). E "o sistema econômico não se sente obrigado a pagar pelos problemas sociais que cria. A contrapartida do trabalho livre é hoje a contrapartida do lucro livre e socialmente irresponsável." (MARTINS 2002. p.30)

OFFE (1984) desvenda "mecanismos seletivos" que filtrariam a assimilação das contradições pelo Estado. São mecanismos institucionais, que, no interior do aparato estatal, fazem a seleção negativa - isto é, excluem sistematicamente da atividade estatal interesses anti-capitalistas: a seleção positiva, que, nas alternativas restantes, escolhe as que favorecem os interesses do capital no seu conjunto, em detrimento de grupos locais $e$ específicos de capitalistas e, finalmente, o mascaramento que são estratégias para manter as aparências de neutralidade. As tensões e conflitos atuam como fontes permanentes de instabilidade para o sistema de poder, que, no âmbito das políticas sociais, tende a concentrar sua intervenção para mitigar as lutas sociais (OFFE, 1984) Se nos regimes 
autoritários as políticas sociais são efetivamente utilizadas em função das necessidades do capital, nos regimes democráticos elas buscam trabalhar as situações de deterioração das relações sociais, com medidas compensatórias.

CASTEL (1991, p.34) considera que na sociedade contemporânea " a zona de integração fratura, a zona de vulnerabilidade está em expansão $e$ alimenta continuamente a zona de desfiliação." E pergunta-se se o único recurso seria reforçar corretivamente a zona de assistência. Porém, além da discussão sobre a questão da autonomia como vetor de inserção, "sobrecarregar" os programas assistenciais é uma estratégia que entra em contradição com o modelo capitalista, onde a assistência é destinada à pobreza residual.

Durante os anos 90, a onda neoliberal defendendo a redução drástica do papel do Estado, causou uma ruptura no processo de formulação e implantação das políticas públicas de caráter universalistas, isso porque "(...) a crise do capitalismo contemporâneo somada à derrocada do Leste Europeu nos anos 80 acabaram por aplainar o caminho para a emergência das teses neoliberais de desmontagem do Estado enquanto instância mediadora da universalização dos direitos e da cidadania." (RICO e RAICHELLIS 1999. p.9)

Vale lembrar que também o poder dos Estados nacionais passou a sofrer um cerceamento progressivo, em função do globalização de áreas estratégicas como as finanças, a comunicação e a informação, mobilizadas 
por mega-empresas transnacionais, com grande "poder de sucção e de rearticulação da economia mundial" (DOWBOR 2002, p.17)

Aumentou a pressão para que o Estado garantisse infra-estrutura para manter o país na divisão internacional do trabalho, provendo condições para a reprodução e expansão do capital privado $e$, concomitantemente, um movimento para tirar de suas mãos serviços sociais específicos, subsidiando - setor privado na prestação desses serviços.

As politicas tiveram de ajustar-se a uma concepção de Estado-mínimo e focalizar, isto é, concentrar os recursos disponiveis. "Isso significa que se prioriza, tomando-se por base aqueles que demandam ao Estado, um determinado serviço público, restando importantes segmentos da população mais pobre (a denominada extrema pobreza ou indigência) fora dessa rede, por desvinculação com ela." (VILLALOBOS 2000, p.51)

Com o não enfrentamento efetivo da desigualdade, a crise do emprego acabou por comprovar que a prevalência da política econômica comandando todos os setores da vida social fez com que as políticas sociais ficassem, na maioria das vezes, restritas a um caráter compensatório, trabalhando com a pobreza residual e com uma concepção de proteção-social de caráter conservador.

Porém, ao mesmo tempo, nos últimos anos, a realidade tem imposto uma profunda transformação, por que " mais recentemente é possivel verificar a formação de um crescente consenso de que o reformismo neoliberal, em todos os paises em que foi adotado, tem sido incapaz de oferecer alternativas aos graves problemas produzidos pelo capitalismo $e$ 
que o custo social do controle da inflação tem sido o profundo esgarçamento do tecido social que mina as bases sociais de sustentação política das sociedade contemporâneas." (RICO e RAICHELLIS 1999, p.10)

Estamos passando "de uma visão filantrópica, de generosidade assistencial, de caridade, de um tipo de bálsamo tranqüilizador para as consciências capitalistas, para a compreensão de que a área social se tornou essencial para as próprias atividades econômicas." (DOWBOR 2001, p.24) Para dar conseqüência à essa visão, o mesmo autor propõe inverter a discussão - a finalidade não é melhorar a educação para as empresas funcionarem melhor, mas gerar consciência de que "educação, saúde e lazer constituem objetivos últimos da sociedade e não um mero instrumento de desenvolvimento empresarial. A atividade econômica é um meio, o bem-estar é o fim." (DOWBOR 2001, p.25)

O compartilhamento de riquezas e oportunidades na sociedade implica a formulação e a implementação de políticas públicas articuladas, que rompam o acúmulo de perdas que gera situações de negação da cidadania $e$ da saúde - compreendida em seu largo sentido de bem-estar físico, psíquico e social - e que expressem, claramente, compromisso político com o sofrimento do outro e com o rompimento da espiral que caracteriza os processos de exclusão.

Por outro lado, é preciso considerar que, no processo de implementação das políticas governamentais, as organizações da Administração Pública têm uma interferência relevante, em virtude da estabilidade de suas práticas institucionais, na relação entre o Estado e a 
Sociedade. É no aparelho do Estado que se instalam os mecanismos seletivos das políticas públicas, de que fala OFFE (1984). Durante o período autoritário, as práticas institucionais acionaram esses mecanismos e, mesmo após a redemocratização, eles continuaram atuando, porém abrindo-se espaços de negociação antes inexistentes.

$O$ formato jurídico-institucional e a articulação do conjunto das organizações que constituem a Administração Pública9 ${ }^{9}$, refletem práticas históricas assim como, por outro lado, vão incorporando, ao longo do tempo, respostas mais ou menos abrangentes a reptos apresentados pela Sociedade ao Governo ${ }^{10}$.

Tem sido freqüente na análise de políticas públicas, a identificação de dificuldades na sua implementação pela Administração Pública. Essas dificuldades têm raizes históricas associadas "o inconcluso processo de

\footnotetext{
9 A estrutura organizacional da Administração Pública, que operacionaliza as decisões governamentais informa sobre a repartição e a hierarquização do poder, bem como sobre a lógica de departamentalização das responsabilidades em relação as ações governamentais e à produção dos serviços públicos .

${ }^{10}$ BRESSER PEREIRA(1998:20) trabalha com o pressuposto de que "existem três formas de administrar o estado: a "administração patrimonialista", a "administração pública burocrática" e a "administração pública gerencial". A primeira - administração patrimonialista - seria do Estado mas não pública, já que não visa ao interesse público, sendo típica dos estados pré-capitalistas, onde se confunde o patrimônio privado do principe com o patrimônio público. Traços dessa administração patrimonialista sobreviveria nos regimes democráticos sob a forma de clientelismo. A administração pública burocrática, "baseada em um serviço civil profissional, na dominação racional-legal weberiana e no universalismo de procedimentos, expresso em normas rígidas de procedimento administrativo." (BRESSER PEREIRA 1998, pp.20) E, finalmente, a administração pública gerencial, filha de um movimento mais amplo, que é o da reforma do Estado e que nasce nos anos 80 , focalizando o ajuste estrutural das economias face às crises do sistema capitalista e de sua apresentação nos paises centrais e dos paises periféricos, e esboçada, no Brasil, a partir de 1995. Esta última tendência teve forte influencia neoliberal.
} 
construção do Estado no Brasil, que não gerara um padrão democrático de relacionamento entre o Executivo e a sociedade nem resolvera a tensão entre 0 vetor patrimonial $e$ o vetor racional-legal que lhe foram constitutivos." (NOGUEIRA 1998, p.168).

As necessidades e demandas da população têm mais chance de entrar na agenda do Estado quanto sua vocalização é suficiente para introduzi-las na arena política de disputa dos diferentes interesses da sociedade. Isso reflete como são as relações entre Estado e Sociedade.

Em um extremo observa-se a concepção do Estado como mera agência a serviço da manutenção dos interesses dos grupos dominantes, em outro, o Estado como fiador das relações sociais - articulador e organizador da Sociedade. Na realidade não se encontram exemplos dessas concepções puras, mas em cada momento histórico é possivel observar em que ponto do continuum entre esses dois extremos cada Estado-nacional está se situando, em função de sua natureza capitalista, que tem de lidar com funções contraditórias, de acumulação e legitimação.

Essa posição relativa em cada momento histórico é que determina 0 desenho das políticas públicas e suas próprias contradições, já que as posições que tendem a um ou outro extremo permeiam grupos em disputa no próprio interior dos Estados democráticos.

Considerando o Estado como o lugar onde reside o poder de arbitragem para resolver os conflitos sociais modelados por interesses contraditórios (MARTINS 1994), espera-se que essa arbitragem seja, em princípio, informada pela garantia dos direitos de cidadania inscritos pela 
sociedade em determinado tempo e espaço. Direitos que, na democracia, estão expressos na Constituição. Entretanto, o Estado não é só poderes, como lembra MARTINS (1994, p.200): "É também debilidades. Para realizar seus próprios fins, precisa de recursos (tangiveis e intangiveis) situados fora de seu âmbito." E é na complexa rede de interdependências que liga Estado e Sociedade, e, atualmente, os Estados nacionais à complexa estrutura transnacional do capitalismo, é que, de um lado são providas as energias necessárias para a formulação e implementação de políticas públicas e, de outro lado, as restrições a essas decisões.

Sem ignorar os constrangimentos estruturais, focalizar a relação entre o Estado e a Sociedade, do ponto de vista da ação coletiva $e$ organização de interesses, sugere que "as escolhas $e$ as decisões em políticas públicas podem resultar de negociação e barganha entre grupos competitivos com interesses $e$ recursos políticos divergentes $e$ assimétricos." (COSTA 1998, p.21)

As relações que a Sociedade estabelece com a Administração Pública extrapolam a apropriação de bens e serviços e incrustam, nas organizações governamentais, representações de interesses especificos de grupos dominantes ou capazes de vocalização, interferindo na implementação das políticas públicas.

Nesse sentido grupos que possuem uma alta capacidade de vocalização de interesses conseguem, muitas vezes, modificar situações a seu favor: Ao contrário, a baixa capacidade de vocalização de interesses - como é típica dos segmentos mais fragilizados da sociedade - dificulta essa interferência. 
Demandas referentes à necessidades de grupos e segmentos da população com menor capacidade de vocalização costumam ser atendidas por políticas públicas que geram ações de caráter compensatório e não transformador ${ }^{11}$, o que é ainda mais grave em um ambiente em que a política econômica mantêm ou agudiza situações de profunda desigualdade social,

Considerado o movimento dialético inclusão/exclusão social e a organização das respostas do Estado à situações em que há ruptura dos laços sociais, é necessário verificar como as demandas são inscritas na agenda governamental.

Como diz MARTINS (1994, p. 178), "a participação é tão antiga quanto - poder político. Os dois fenômenos são coetâneos, porque um suscita automaticamente o outro: instituído um poder supremo no âmbito de dada coletividade, ato contínuo haverá integrantes desta coletividade desejosos de influir diretamente no processo pelo qual são tomadas decisões que afetam as condições de sua existência."

A participação acompanha o Estado nacional moderno ao longo dos tempos e o que varia são os conteúdos que expressa, os sujeitos e os modos pelos quais é praticada.

A representação é uma forma de participação engendrada no processo civilizatório. As sociedades abrigam formas de participação representativa e formas de participação direta, isto é agrupamentos populares influindo diretamente em processos decisórios governamentais.

\footnotetext{
"Entende-se aqui como demandas de caráter compensatório aquelas que não visam a reversão estrutural da exclusão mas, apenas, garantir o provimento pontual de algum bem
} 
Ambas as formas de participação, e suas diversas maneiras de efetivar-se, buscam um objetivo comum: influir na implementação e na condução pelo Governo das políticas públicas formuladas pelo Estado, de modo a conduzir a resultados que contemplem interesses peculiares. É claro que a participação é sempre do interesse dos indivíduos e grupos que a reivindicam para si $e$, portanto, includente de alguns e excludente dos demais (MARTINS 1994, p.181), embora, idealmente, possa significar uma melhoria do entrosamento Estado-sociedade, suprindo lacunas, eliminando desencontros, corrigindo defeitos e contribuindo para elevar a qualidade da performance estatal $e$ o índice geral de bem-estar da coletividade (MARTINS 1994, p.182)

O conceito de movimento social nasceu estreitamente vinculado ao protagonismo da classe trabalhadora no cenário público, no século XIX.

O movimento da classe operária, definida por TOURAINE (1999, p.88) como a defesa da autonomia operária, invadida pela racionalização industrial, capitalista ou socialista, era, portanto a defesa corporativa de uma posição no mercado de trabalho e uma luta contra um produtivismo que acarretava novas formas de exclusão. Já no início dos anos 60 esse autor anunciava "o ocaso da consciência de classe operária e, portanto, do sindicalismo como um movimento social" (TOURAINE 1999, p.88)

As transformações da sociedade, as profundas mudanças no mundo da produção que esgarçaram as possibilidades de inserção social pelo

ou serviço. 
trabalho, implicaram a reelaboração do conceito de movimento social vinculado a classe trabalhadora.

Com o enfraquecimento dos movimentos sociais organizados, protagonistas do momento histórico anterior, como foi o caso do sindicalismo, fortaleceram-se movimentos identitários - raça, gênero, etnia - ou de interesses, sob a lógica consensual-solidarística, que privilegiam a ação direta.

Em uma base social dispersa e fragmentada, multiplicaram-se "grupos identitários em torno de sinais culturais distintivos, a exemplo dos movimentos étnicos, nacionalistas e xenófobos, ou mesmo das redes do crime organizado." (DOIMO 1997, p.130).

Esses movimentos pautam-se pela ação direta, grupos de individuos que formam grupos de interesse e apresentam demandas diretamente aos centros decisórios dos aparatos do Estado, por fora da intermediação das instituições políticas de representação, como as partidárias e as sindicais.

De outro lado, com a introdução de modificações relevantes na vida política do país, decorrentes da mudança do capitalismo internacional, com novos elementos de consumo cultural e de organização do trabalho, cresceu, em setores influentes da sociedade, a tendência à defesa da restrição da intervenção do Estado na vida social. Essa tendência revelou-se no apoio, por esses segmentos, à privatização de serviços públicos. 
O Estado, por sua vez, ao abrir em seu aparato um conjunto de espaços conselhistas, que abrigam esses grupos identitários e de interesses, promove a inevitabilidade da ação-direta.

De um lado, pode-se fazer uma leitura de que as propostas utópicas de uma nova sociedade, de alternativas radicais ao capitalismo, perderam espaço e setores representativos da sociedade começaram a apostar em intervenções consideradas práticas e a privilegiar áreas temáticas. De outro lado, é preciso reconhecer que o conjunto das mudanças produzidas pela acelerada modernização econômica e social das últimas décadas mexeu com práticas enraizadas, costumes e idéias, abalou comportamentos e expectativas políticas, incorporou a progressiva $e$ irrefreável universalização dos direitos sociais e, assim, "trouxe enormes desafios para - Estado, problematizando especialmente o desempenho governamental e a eficácia/eficiência da Administração Pública." (NOGUEIRA 1998, p.216-217)

Desse processo nasceu uma sociedade civil "encorpada", na expressão de Nogueira, "mas alimentada pela convicção de que se faria a si mesma na medida em que se diferenciasse e se opusesse, como um alter, ao Estado." (NOGUEIRA 1998, p.216), Nesse suposto fortalecimento, entretanto, reside a fragilidade da fragmentação e da anomia ideológica.

Os grupos identitários, que tendem a intransigência e a ações movidas por interesses particularistas, e os grupos de interesse consensualsolidarísticos são vulneráveis ao agenciamento, na medida em que se mobilizam para objetivos imediatos, de curto prazo, para alcançar bens $e$ serviços de que seus integrantes carecem. Distanciados de utopias e até 
mesmo repudiando ideologias político-partidárias, a ação desses grupos é permeada por ambigüidades viscerais: "ao mesmo tempo em que contestam o Estado por sua baixa capacidade de implementação de políticas sociais, legitimam sua existência porque dependem de sua função provedora; ao mesmo tempo em que recusam a acumulação privada e o mercado em razão do seu perfil excludente, legitimam a lógica do lucro porque dela deriva o excedente que irriga o fundo público, do qual dependem para o atendimento de suas carências." (DOIMO 1997, p.135)

TOURAINE (1999) diz que uma das razões porque a ação coletiva não se organiza de uma nova forma é que "o campo político ainda está ocupado pelos representantes de antigos movimentos sociais hoje em vias de desaparecimento. Os partidos e os sindicatos, que estiveram ligados aos grandes conflitos da sociedade industrial, sejam eles de direita ou de esquerda, há muito tempo deveriam ter se tornado agentes de gestão das mudanças impostas pelas transformações da economia mundial e pelos modos de vida" (TOURAINE 1999, p.357)

Em muitos paises a continuidade de antigos confrontos conduziu à derrota dos sindicatos e à desorientação dos partidos de esquerda ou ao triunfo da ortodoxia liberal. Os grupos de ativistas e quadros de pensamento e de ação que subsistiram tornaram-se, por sua vez, "obstáculos poderosos para uma renovação dos movimentos coletivos." (TOURAINE 1999, p.357)

No campo institucional, as ONG - Organizações Não Governamentais passaram a assumir, nesse cenário, um papel na mediação entre instituições 
da sociedade civil e o Estado que outrora não tinham. Porém as ONG não nascem na base do movimento popular ou sindical, mas na classe média, sendo uma parte delas vinculada a movimentos identitários.

Não são novas as Organizações que nascem na esfera privada voltadas para fins públicos, com sua raiz na filantropia, como uma forma de participação direta na própria operacionalização de políticas públicas, de modo articulado ou desarticulado com a administração pública. Entretanto, parecem novidade quando surge no discurso a pretensão desses grupos organizados a substituir a própria administração pública ou disputar espaço com ela.

Também não é pouco importante observar que as ONG têm, na sua maioria, trabalhado com um modelo de operação semelhante ao do Estado, embora afirmem que com maior eficácia, e seus operadores freqüentemente são oriundos da mesma classe média que perderam seus tradicionais postos de trabalho no aparelho estatal, com o "enxugamento" desse aparelho, no bojo das reformas administrativas de caráter neo-liberal.

Juntamente com o esvaziamento dos movimentos sociais tradicionais, menos como novidade e mais como a organização do espólio, emergiram dois novos locus de ação da sociedade civil organizada, tendo como espaços de mediação, as ONGs, agremiações religiosas e instituições de participação regulada, como os conselhos.

Por outro lado, "nossas sociedades, expostas a uma insegurança cada vez maior, de fato tendem a sacrificar ao mesmo tempo os inovadores e os excluidos para defender as classes médias públicas e privadas, que são 
majoritárias e bem organizadas, o que só deixa escolha entre um liberalismo brutal, que acarreta custos sociais elevados, e uma política de intervenção estatal, que é exercida mais em proveito da defesa de interesses adquiridos do que de um reforço da economia ou de uma diminuição das desigualdades sociais." (TOURAINE 1999, p.349)

Além disso, vale lembrar que o mundo dominado pela mídia "transtorna completamente a noção de representação" (ROSANVALLON 1992, p.105), impossibilitando a existência de intermediários claramente identificáveis. Isso aconteceria porque através dos meios de comunicação de massa a sociedade tem a ilusão de estar em uma situação de representação permanente, ilusão que desestimula a necessidade de organização de grupos e que pode levar a representação a se banalizar e se balcanizar reforçando a chamada ação direta.

Nesse ambiente, onde muitos dos interlocutores coletivos mudaram de face e se institucionalizaram, onde o cenário social parece vazio, as pessoas imersas na espiral de perdas, excluídas do acesso a mínimos sociais, com sua rede social esfarrapada, não encontram, nas novas instituições, locais de articulação de seus direitos nem de encaminhamento de suas demandas ao Estado, mas sim locais de provimento desarticulado de alguns bens e serviços. Pode configurar-se, assim, um processo mais assistencialista. As políticas governamentais, que já respondiam fragmentadamente ao cidadão, passam a receber uma pressão menos articulada do que quando conversavam com movimentos sociais de base. 
A assistência é uma estratégia formulada para a pobreza residual. Embora represente uma forma de inserção, trata-se de uma inserção dependente, pois não se dá pela integração autônoma ao trabalho e se pode, em alguma medida, preservar alguma capacidade relacional dos assistidos, certamente não contribui para potencializar a sua vocalização.

De qualquer vertente de análise, o que se observa é que a parcela da população imersa na espiral de perdas fica cada vez mais distante da possibilidade de se engajar em movimentos sociais onde consigam articular sua própria voz numa perspectiva de transformação social, de redução da desigualdade.

\section{Capítulo 3 - Proteção social, vocalização e trabalho no Brasil e em São Paulo}

Ao longo de décadas, o Brasil criou, na periferia do mundo capitalista, - que FARIA (2000) considera um dos maiores e mais complexos, embora perverso, sistema de proteção social de tipo estatal-corporativo com influências democrata-cristãs. Esse sistema comportou desde os primeiros esforços de Elói Chaves, na década de 20, o impulso institucional e expansivo da era Vargas, a modernização conservadora realizada pela ditadura militar entre 1964 e 1978, até o projeto consagrado na Constituição de 1988, configurando um sistema de proteção social importante, associado ao regime de crescimento baseado na industrialização substitutiva de importações conduzida pelo Estado. (FARIA 2000, p.37). 
A leitura comparativa das políticas públicas do período autoritário e a tentativa de configuração das bases de um Estado de bem-estar presente na elaboração da Constituição de 88 , na redemocratização do país, ilustram as teses de OFFE (1984) sobre os mecanismos seletivos de assimilação das contradições sociais pelo Estado.

Porém, a exaustão do modelo de crescimento, impactado pela fase global do capitalismo, e o recrudescimento inflacionário, puseram em crise o sistema de proteção social, que, segundo FARIA (2000, p.23), já se caracterizava como "regressivo do ponto de vista distributivo" e "de séria ineficiência funcional" , antes mesmo de que o novo modelo tivesse condições de ser experimentado.

$\mathrm{Na}$ década de 70, contrapondo-se ao regime autoritário e em um cenário de restrição de liberdade de associação e de participação na vida política do pais, movimentos populares surgiram ou se fortaleceram. Por duas décadas os canais tradicionais de participação - partidos políticos e sindicatos - estiveram atados e o Estado não negociava.

O movimento sindical esteve, como outros movimentos populares, na oposição ao regime autoritário que vigorou no país na década de 70 , lutando pela redemocratização do Estado, como condição para superar as inequidades sociais.

Além do movimento sindical, movimentos reivindicatórios urbanos fizeram emergir uma nova ação coletiva. JACOBI (1989) trabalha com os movimentos por saneamento básico e saúde em São Paulo demonstrando que "eles se desenvolvem principalmente como reflexo da precariedade ou falta 
de condições dos canais de representação, ou de arranjos institucionais existentes no período autoritário."

Os movimentos populares foram vigorosos, de enfrentamento ao autoritarismo, mas não ao Estado em si, que almejavam transformar, para que se permeabilizasse à população e promovesse justiça social. Eles se contrapunham a um Estado que não negociava, num cenário de negação dos canais tradicionais de participação representativa - partidos políticos e sindicatos. A atuação dos movimentos era agressiva, não com o objetivo eliminar o Estado mas, sim, de transformá-lo, para que se abrisse à participação e fizesse justiça social.

Até os anos 80, o Estado exerceu o papel central na formulação de políticas sociais, organizando a provisão e a gestão dos benefícios sociais setorialmente - saúde, educação, moradia, trabalho e previdência. Essa organização deu origem a estruturas federais, estaduais e municipais de caráter setorial.

A concepção de direitos universais levou a esses setores projetos de caráter universalistas - saúde para todos, educação para todos, moradia para todos. Sem o amparo de uma política econômica redistributiva, contavase com um crescimento econômico suficiente para financiar essas políticas sociais universalistas.

Na década de 80 , em meio à crise da Previdência Social e no bojo da redemocratização do país, discutiu-se intensamente direitos de cidadania sob o prisma do modelo universalista, que, em parte, iria, tardiamente, instalar-se na Constituição Federal de 1988. 
A redemocratização, após 20 anos de governo autoritário, desaguou no processo constituinte, carregando como idéia-força a do Estado do BemEstar Social, já em crise nos paises centrais. Havia, então, um movimento de conquista de espaço da cidadania, que se expressou, na Constituição de 1988 , na institucionalização de conselhos e outros mecanismos de participação regulada, isto é, organizada e articulada com sistemas e órgãos da Administração Pública, através da qual o Governo implementa as políticas públicas.

Com a redemocratização, os movimentos se direcionam para inserir na Constituição um modelo de proteção social, que já estava em crise nos países centrais. Nesse tempo, o mundo da produção estava em acelerada transformação e a onda neo-liberal já punha em cheque benefícios oriundos das chamadas conquistas sindicais e pregava o enxugamento do Estado. $O$ capitalismo já abandonava, nos países centrais, os mecanismos de Bem Estar de que se utilizava para controlar a pobreza e fazia ouvir novamente as teses neo-liberais, acusando o Estado de gastador e de ineficiente e garantindo que o Mercado se auto-regula. Essas teses neo-liberais, que andaram circulando pelos países centrais, aportaram como toda a força nos países periféricos, desmontando parte do aparato estatal em nome da eficiência.

Estudo do NEPP (Núcleo de Estudos de Políticas Públicas da UNICAMP), publicado no final dos anos 80 , sobre a situação social do Brasil salientou a distinção entre a situação das políticas de bem-estar social nos países desenvolvidos e no Brasil, considerando que naqueles as políticas 
ocorriam em um ambiente de pleno emprego e elevação dos níveis de vida da maioria da população, mas por aqui, na medida em que tinham de enfrentar as carências de praticamente um terço da população, tendiam a se 'assistencializar' e os programas voltados para combate à miséria a ficar 'sobrecarregados' (NEPP 1988, p.6-11) 12

Com o fortalecimento do neo-liberalismo a movimentação geral, porém, tomou outro rumo. $O$ rumo determinado pela supremacia do Mercado, que ordenava a redução drástica do Estado. A globalização passou a ser uma variável relevante da política do país, introduzindo outros elementos de consumo cultural e de organização do trabalho. Entretanto, "o desenvolvimento econômico que gera um desenvolvimento social muito aquém de suas possibilidades como ocorre nos países do Terceiro Mundo e como ocorre no Brasil, nega-se na perversidade das exclusões sociais que dissemina." (MARTINS 2002, p.9)

O descompromisso politico com o sofrimento do outro, de que nos fala SAWAIA (1999, p.8) revela-se na análise de que o Brasil "não é um país pobre, mas um país injusto" (BARROS 2000, p.11), o que resulta da intensa desigualdade na distribuição da renda e nas oportunidades de inclusão

12 Entretanto é importante registrar o exemplo positivo da política de saúde - com o Sistema Único de Saúde - que, tendo origem no Movimento Sanitário na década de 70 e inserindo-se como política pública na Constituição de 1988, subsistiu em seus fundamentos, tendo demonstrado a vitalidade de um projeto universalista e promotor da equidade. $E$ isso apesar das dificuldades naturais face à diversidade de situações de saúde e gerenciais existentes nos estados e nos municípios da federação, bem como dos limites orçamentários e financeiros do Sistema. 
econômica e social. A pobreza, no Brasil, não está associada a escassez de recursos, pois o país é relativamente rico ${ }^{13}$, mas à desigualdade ${ }^{14}$.

A desigualdade nunca foi efetivamente enfrentada com politicas redistributivas. As experiências de redução do nível de pobreza no Brasil sempre estiveram associadas a períodos de crescimento econômico, apoiadas na teoria do derrame - crescendo a riqueza automaticamente se reduziria a pobreza.

Ao advento da Constituição Federal de 1988, seguiu-se um governo cujas políticas eram mais compativeis com a ideologia neo-liberal do que com a filosofia da proteção social de caráter universalista. Com o fortalecimento da visão neo-liberal, que também desembarcou por aqui tardiamente, a movimentação foi tomando outro rumo $e$ instalando ou agudizando as contradições entre as políticas públicas econômica e social.

As mudanças no capitalismo internacional introduziram modificações relevantes na vida política do país, com novos elementos de consumo cultural e de organização do trabalho. A mudança no mundo do trabalho e o crescente desemprego minou os movimentos sindicais e desarticulou o poder de vocalização das representações dos trabalhadores.

\footnotetext{
${ }^{13}$ A análise da estrutura da distribuição de renda mundial, a partir dos dados do Relatório de Desenvolvimento Humano de 1999. permite inserir o Brasil entre o terço mais rico dos paises do mundo (BARROS 2000, p.17)

${ }^{14} O$ coeficiente Gini do Brasil, com um valor próximo do 0,60 , nos coloca entre os quatro paises com maior desigualdade entre 92 paises do mundo (Dados do Relatório do Desenvolvimento Humano de 1999 - PNUD) FARIA (2000, p.43) cita estudo do Banco Mundial dando conta que, no Chile, $36 \%$ dos gastos sociais iam para os $20 \%$ mais pobres e apenas $4 \%$ dos gastos para os $20 \%$ mais ricos, porém, no Brasil, $15 \%$ dos gastos iam para os mais pobres e $21 \%$ para os mais ricos.
} 
Do ponto de vista do movimento da sociedade organizada, verificou-se um enfraquecimento importante do movimento sindical, de um lado, e de outro, o recuo da Igreja católica, que havia amparado parte da movimentação política nos anos 60 e 70 .

Os movimentos populares, por sua vez, inseriram-se nos espaços de cidadania regulada, nos conselhos, com poucas exceções, como o MST (Movimento dos Sem-Terra). Fortaleceram-se, de outro lado, movimentos identitários, que expressam grupos de interesse étnicos, de gênero e até de doenças, que focalizam condições específicas de grupos vulnerabilizados mas não a desigualdade e a pobreza.

De um lado, o enfraquecimento e a fragmentação das representações dos trabalhadores, de outro lado, pelo fato da precarização das relações de trabalho terem sido rotuladas como uma flexibilização necessária ao novo modo de produção e assim vendidas à sociedade pelos agentes do neoliberalismo, não se mobilizou na Sociedade força política suficiente para criar uma plataforma de negociação envolvendo o Estado e os empresários.

As ONGs - Organizações Não Governamentais - surgem também por aqui como instituições da sociedade civil para mediar a sua negociação com o Estado, que, em função da visão neo-liberal, deve restringir-se mais e mais.

É visivel, nos anos 90 , a tendência à institucionalização de movimentos populares. O governo instituiu a participação consentida, através de conselhos acoplados aos sistemas de saúde, de assistência social, de educação. De outro lado, grupos identitários com capacidade de vocalização começaram a enxergar as organizações não governamentais como lugar 
preferencial e prático de intervenção na execução de políticas públicas e em situações sociais criticas.

Nesse contexto, parece configurar-se, no que diz respeito ao movimento da sociedade civil, uma supremacia da organização sobre a utopia. As propostas utópicas de uma nova sociedade, de alternativas radicais ao capitalismo, perderam espaço e a sociedade começou a apostar em intervenções consideradas práticas e a privilegiar áreas temáticas.

De algum modo a sociedade acreditou na história da auto-regulação do Mercado e que o Estado mínimo poderia servir a seus interesses. Entretanto, o Mercado não comporta nenhum dos elementos necessários à coesão social. O Mercado funciona pela concorrência e "não faz sociedade" (CASTEL 2000, p.257).

Na última década do século $X X$ ○ Brasil combateu a inflação que combalia sua economia, empreendeu a privatização do setor produtivo estatal e a reforma administrativa de parte do aparato estatal $e$, simultaneamente, reformulou políticas públicas.

Houve uma variação positiva de $41,9 \%$ na comparação entre o rendimento médio mensal dos chefes de domicílio com renda, entre os anos 1991 e 2000, no Brasil, como mostram os dados dos censos demográficos, realizados pelo IBGE - Instituto Brasileiro de Geografia e Estatística Entretanto, há que registrar que essa variação é bastante desigual entre as regiões e os municípios e que, no mesmo período, ampliou-se a quantidade de chefes de domicílio sem rendimento: "um em cada dez chefes de familia vivem sem rendimento monetário em 2000" (SDTD-a 2002, p.3). 
Análise da Secretaria do Desenvolvimento, Trabalho e Solidariedade da Prefeitura do Município de São Paulo (SDTD-b, 2002) com os dados censitários mostra que, entre 1991 e 2000, o rendimento médio mensal dos chefes de domicílios com renda no Estado de São Paulo registrou variação 10,3\% menor do que a média dos 27 estados brasileiros. Essa análise dá conta de que ocorreu uma forte contenção do emprego industrial no estado de São Paulo, que atingiu particularmente os municípios fundados na atividade manufatureira. "A perda de emprego industrial afetou desfavoravelmente o Estado de São Paulo, comprometendo as possibilidades de redução da desigualdade de rendimento entre os chefes de domicílio." (SDTD-b 2002, p.11)

Em contrapartida, nos anos 90 , cresceram as ocupações informais "na maior parte de baixa remuneração e precárias condições e relações de trabalho." ( SDTD-b 2002, p.12) E o desemprego explodiu em São Paulo

Em 1999 a taxa de desemprego aberto no estado de São Paulo alcançava, segundo o IBGE, quase $13 \%$ do total de sua PEA - População Economicamente Ativa, sendo que na Região Metropolitana era de $16 \%$, significando mais de dois milhões e duzentas mil pessoas desempregadas em todo o Estado. Segundo a metodologia utilizada pelo SEADE (Pesquisa de Emprego e Desemprego, SEADE/DIEESE) a taxa de desemprego chegava a 19,3 .

Trabalhando com dados da Pesquisa Mensal de Emprego (PME/IBGE), em Recife, Salvador, Belo Horizonte, Rio de Janeiro, São Paulo e Porto Alegre, ROCHA (2001, p.81) diz que no período de 1995 a 1998, nessas seis regiões metropolitanas, que são responsáveis por $30 \%$ da população 
brasileira, diminuiu em 1,14 milhão o número de postos de trabalho ocupados por pessoas com menos de 4 anos de escolaridade, que passaram de $34 \%$ a $25 \%$ da mão-de-obra ocupada nessas metrópoles. Como efeito combinado da redução do número de postos de trabalho e do rendimento médio, o rendimento total do trabalho para essa categoria de trabalhadores caiu $26 \%$ em termos reais no mesmo período.

No contexto do capitalismo contemporâneo São Paulo é um exemplo do novo desemprego ${ }^{15}$, aquele que "surge não da falta de crescimento, mas do próprio crescimento" (DOWBOR 2002, p.13).

São Paulo, estado mais rico do país, exibe elevado nível de acumulação de riqueza e extrema desigualdade. Na década de 70, ainda no período autoritário, um grupo de estudiosos, sistematizando dados de natureza econômica e social, ousou discutir essa situação: São Paulo 1975 Crescimento e Pobreza (1976). O estado de São Paulo reunia, naquele momento, 19\% da população do país e concentrava $35 \%$ da sua riqueza. Tal superioridade econômica já era baseada na propriedade do capital, tratando-se " de uma econômica em que os meios de produção mais importantes são propriedade de não-produtores, que os administram diretamente ou por representantes." (CAMARGO et.al 1976, p.14) E "12,5\% da Força de Trabalho são trabalhadores autônomos" (CAMARGO et. al 1976, p.15). Esse estudo anunciava que" a lógica da acumulação que preside ao desenvolvimento brasileiro recente apóia-se exatamente na dilapidação da força de trabalho" (CAMARGO et.al 1976, p.59) Com as inovações tecnológicas na produção o

\footnotetext{
${ }^{15}$ Conceito de jobless growth com que a ONU trabalha.
} 
emprego em geral já não acompanhava o crescimento da população, identificando-se "um ciclo de vida produtiva em que as empresas podem utilizar abusivamente de sua força de trabalho, alijando a mão-de-obra desgastada do mercado de trabalho." (CAMARGO et.al 1976, p. 83). Surge o "velho prematuro", condição que irá alargar-se nas décadas subseqüentes, onde permanecerão também as discriminações de raça e de gênero, em relação a tipo de ocupação e a salários.

A taxa de desemprego, crescente nos anos 80 e 90, mostra como a situação evoluiu.

Tabela 1 : Taxa de Desemprego, segundo Tipo de Desemprego

Região Metropolitana de São Paulo 1985-2000

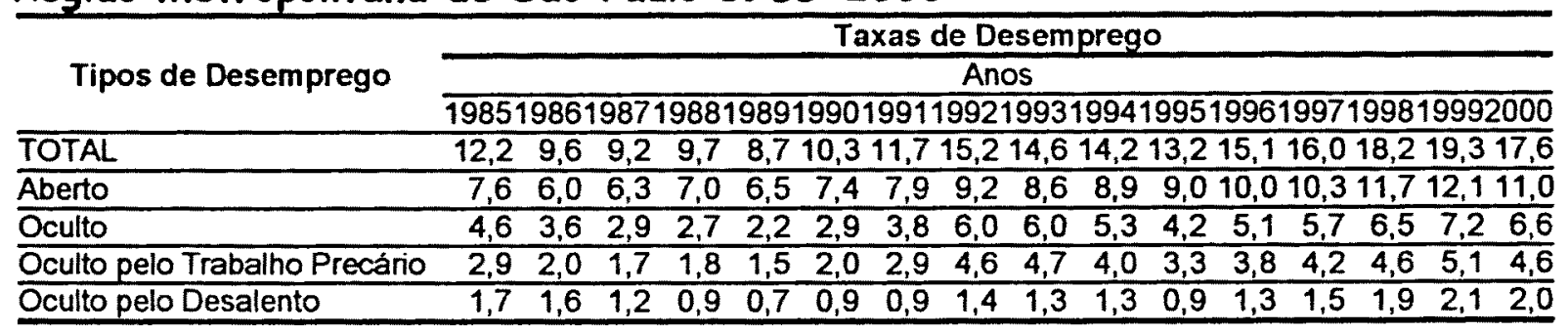

Fonte: SEP. Convênio SEADE-DIEESE. Pesquisa de Emprego e Desemprego.

Além do crescimento total é notável, na década de 90, a escalada da precarização do trabalho $e$, no seu final, a taxa de desemprego oculta pelo desalento. Desalento que se explicita, dramaticamente no tempo despendido na procura de trabalho a partir de 1998.

Tabela 2: Tempo Médio Despendido pelos Desempregados na Procura de Trabalho, segundo Tipo de Desemprego Região Metropolitana de São Paulo 1985-2000

\begin{tabular}{|l|r|r|r|r|r|r|r|r|r|r|r|r|r|r|r|r|}
\hline \multirow{3}{*}{ Desemprego } & \multicolumn{10}{|c|}{ Tempo Despendido na Procura de Trabalho em semanas } \\
\cline { 2 - 14 } & \multicolumn{10}{|c|}{} \\
\cline { 2 - 12 } & 1985 & 86 & 87 & 88 & 89 & 90 & 91 & 92 & 93 & 94 & 95 & 96 & 97 & 98 & 99 & 2000 \\
\hline Média & 25 & 17 & 14 & 15 & 15 & 16 & 18 & 23 & 26 & 25 & 22 & 24 & 28 & 35 & 44 & 48 \\
\hline
\end{tabular}

Fonte: SEP. Convênio SEADE-DIEESE. Pesquisa de Emprego e Desemprego. 
Em escala crescente importantes parcelas da população da Região Metropolitana de São Paulo são expulsas do mundo do trabalho e tornam-se vulneráveis às muitas rupturas que essa situação causa no tecido social. Considerando essa exclusão como deflagrador da espiral de perdas, há que considerar que ela veio ocorrendo sistemática e progressivamente, o que sugere que as políticas públicas levadas a efeito nesse período não podem ser consideradas exitosas.

A crise do trabalho gera mais pobreza e instaura um círculo vicioso: " a fragilidade econômica da imensa massa de pobres do país se traduz em fragilidade política e na conseqüente dificuldade de gerar politicas econômicas redistributivas." (DOWBOR 2002, p.62)

0 enfraquecimento dos movimentos populares concomitante à fragilização das relações de trabalho $e$ ao surgimento do desemprego estrutural roubaram a capacidade de vocalização da população imersa na espiral de perdas que caracteriza o processo de exclusão social.

Essa dimensão da mobilização é muito importante para a reflexão sobre fatos desse período, porque o poder é sempre um potencial que "passa a existir entre os homens quando eles agem juntos, e desaparece no instante em que eles se dispersam." (ARENDT 1981, p.212).

Assim, é nesse ambiente, com a instalação de um nivel de desemprego estrutural e a redução drástica da capacidade de vocalização dos pobres, que o Estado formula sua política pública no final dos anos 90. 


\section{PARTE II}

\section{OBJETIVOS E METODOLOGIA}

Esta parte tem o propósito de explicitar os objetivos e a metodologia utilizada para construir e analisar o discurso do frentista como sujeito coletivo, bem como apresentar o processo de trabalho desenvolvido para cotejar esse discurso com o discurso do governo sobre a concepção, estratégias e resultados pretendidos com a implementação do Programa focalizado.

\section{Capitulo 4 - Objetivos}

O Programa Emergencial de Auxílio Desemprego - PEAD se inscreve em uma política governamental que se explicita como assistencial e focaliza um segmento da população em situação de desfiliação. Essa relação ocorre em uma conjuntura de crescimento do desemprego na Região Metropolitana do Estado de São Paulo.

Os objetivos desta pesquisa são:

- apresentar a visão do frentista sobre o Programa Emergencial de Auxílio Desemprego - PEAD - e

- verificar, a partir desse discurso, a consistência entre a proposta do PEAD e os resultados percebidos pela população que visa a beneficiar. 


\section{Capítulo 5 - Metodologia}

\subsection{0 discurso do sujeito coletivo e suas fontes}

O discurso de um indivíduo expressa uma leitura da situação que não é só dele, mas também, em alguma medida, do grupo a que pertence, ainda que esse pertencimento não se traduza numa ação coletiva intencional, organizada. Através dos seus discursos os vários sujeitos coletivos de uma sociedade, num dado momento histórico, buscam estabelecer um processo de comunicação que dê conta dos interesses e desejos individuais e de grupo - de mudar o contexto.

Além disso, todo discurso é recoberto pela memória de outros discursos (MAINGUENEAU 2000, p.96). Nesse sentido, também o discurso é coletivo, pois a memória é uma construção social, um processo psico-social de representação de si próprio, que fornece quadros de orientação e códigos para classificação e para o intercâmbio social (MENEZES 1992, p.22).

Acreditando que discursos individuais estão carregados de discursos coletivos, ainda que a ação coletiva não esteja organizada, é que se buscou trabalhar o material da pesquisa - documentos que expressam o discurso do governo sobre o Programa Emergencial de Auxílio Desemprego (PEAD) e documentos que expressam o discurso da população focalizada por essa política pública - utilizando a abordagem metodológica do Discurso do Sujeito Coletivo, conforme nos apresentam LEFÈVRE, LEFÈVR eTEIXEIRA $(2000)^{16}$.

\footnotetext{
${ }^{16}$ A escolha do Discurso do Sujeito Coletivo não foi feita em função de críticas a outras metodologias, como a análise de conteúdo, por exemplo, mas por considerar que a
} 
$O$ material da pesquisa tem dois tipos de fonte: o governo e os frentistas.

a) As fontes do discurso oficial sobre O PEAD

Para apreender o discurso do Governo sobre o PEAD, foram selecionados quatro tipos de documentos:

\section{Legislação: leis e decretos que criam e regulamentam o Programa;}

Lei $n^{\circ} 10.321$, de 8 de junho de 1999, publicada no D.O E., em 8 de junho de 1999, cria o Programa Emergencial de Auxílio-Desemprego

Lei $n^{\circ} 10.618$, de 19 de julho de 2000, publicada no D.O E. de 20 de julho de 2000, altera a Lei $n^{\circ} 10.321$, de 8 de junho de 1999

Decreto $n^{\circ} 44.034$, de 8 de junho de 1999, publicada no D.O E, em 9 de junho de 1999, regulamenta a Lei $n^{\circ} 10.321$, de 8 de junho de 1999;

Decreto $n^{\circ} 44.731$, de 28 de fevereiro de 2000 , publicada no D.O E, em 29 de fevereiro de 1999, prorroga por 3 (três) meses o prazo de concessão dos benefícios aos bolsistas e autoriza a SERT a celebrar contratos, convênios e outros ajustes necessário à execução do PEAD pelo prazo complementar

Publicações da Secretaria do Emprego e das Relações de Trabalho que gerencia o PEAD:

abordagem eleita contribui, de maneira singular, para o objetivo de apresentar a visão do frentista através da sua própria expressão. 
Programa de Qualificação Profissional nas Frentes de Trabalho Documento-Base, Governo do Estado de São Paulo, SERT, junho de 1999

São Paulo na Frente pelo Trabalho: transformando crise em crescimento. Governo do Estado, SERT, julho de 2000

Uma construção em pleno vôo Frentes de Trabalho Transformando crise em crescimento, São Paulo: Governo do Estado, SERT, Folheto tipo encarte, sem data, sem paginação.

\section{Relatórios}

Relatório do Programa Emergencial de Auxílio Desemprego - PEAD Frentes de Trabalho, SERT, setembro de 1999

Relatório de Pesquisa - Programa Emergencial de Auxílio Desemprego.

São Paulo: FUNDAP/SERT, 2000 (mimeo)

\section{Cartas-resposta às cartas dos frentistas}

Os documentos legais que compõem o primeiro conjunto foram escolhidos por constituírem o núcleo do discurso oficial do governo, inicial e de ajustes, sobre o PEAD.

A criação, por lei, de um programa oficial de governo, em princípio, é resultante de um diálogo entre o Executivo e o Legislativo e revela o acordo entre esses dois grupos que compõem o governo em determinado momento histórico. É competência legal do Executivo regulamentar a Lei, através de Decreto. Quem representa o falante no discurso legal é o Governador do Estado. 
$O$ conjunto da Legislação e normas dela decorrentes anunciam o Programa para a população em geral e especificam as regras que orientarão a participação da população focalizada. Assim, de forma direta, tendo acesso aos documentos, ou indireta, sendo orientados pelos gestores do PEAD, os frentistas tomam conhecimento dessa informação sobre quem pode participar, quais são as regras básicas para a participação, tempo, benefícios, condições de exclusão, etc.

Compõem o segundo e o terceiro conjuntos documentos do Executivo, tendo como autor o Governo do Estado, através da Secretaria do Emprego e das Relações de Trabalho. Esses documentos foram escolhidos como constituintes do discurso oficial porque nele são recuperados os pontos principais do Programa e apresentados resultados do ponto de vista do governo, coincidindo com o período selecionado para a análise do discurso dos frentistas.

E as cartas-resposta, cópias das cartas enviadas pela Secretaria do Emprego e das Relações de Trabalho aos frentistas, em resposta às suas cartas. Essas cópias, assim como as cartas dos frentistas, estão armazenadas na Coordenação do Programa Emergencial do Auxílio Desemprego, em ordem cronológica.

Utilizou-se técnicas da mesma metodologia de construção do discurso do sujeito coletivo para decompor, desconstruir o discurso oficial, no sentido de melhor compreendê-lo. 


\section{b) A fonte do discurso dos frentistas}

A fonte do discurso dos frentistas são as cartas de indivíduos participantes do Programa Emergencial de Auxílio Desemprego - PEAD, espontaneamente enviadas ao Governo.

Essas cartas são armazenadas pela Coordenação do Programa na Secretaria do Emprego e das Relações de Trabalho, em ordem cronológica, juntamente com as cópias das cartas-resposta.

O fluxo das cartas varia segundo a época do ano. Foi escolhida uma amostra intencional do período de janeiro a agosto de 2000. As 344 cartas desse período pertencem a um momento em que o Programa já estava em funcionamento $e$ as primeiras turmas já tinham concluído seu tempo de vinculação ao Programa. Com esse critério procurou-se excluir manifestações iniciais de entusiasmo e privilegiar um periodo em que a experiência já havia sido vivenciada no todo ou em parte pelos manifestantes. Isso porque a pesquisa visa captar a percepção de mudanças introduzidas na vida do sujeito pelo Programa e não apenas a sua expectativa.

Entretanto, com essa opção foi introduzido um elemento importante a angústia pelo final do período de 9 meses de trabalho transborda de grande parte das cartas. Em janeiro de 2000 parte dos frentistas tinha 5 meses de trabalho e, em princípio, seu período de 6 meses terminaria no final de fevereiro. Porém o prazo foi prorrogado por mais 3 meses e isso foi 
se repetindo para os frentistas integrados ao Programa daí por diante, já que o limite legal é de 9 meses. ${ }^{17}$

Algumas cartas têm data anterior a janeiro de 2000 ou posterior a agosto de 2000. Optou-se por considerar o período pelas datas das respostas porque as cartas dos frentistas nem sempre são datadas. Todas as cartas foram numeradas, para que pudessem ser trabalhadas sem a identificação do autor.

Nas cartas que constituíam o universo inicial da pesquisa verificou-se, no processo, que as cartas numeradas de 104 a 112 não diziam respeito ao período definido para a pesquisa (outubro de 2000 a janeiro de 2001), o que motivou a opção de excluí-las. Assim, ficamos com um universo de 335 cartas.

Gráfico 1: Distribuição mensal das Cartas da Frente recebidas e respondidas pelo PEAD, no período de janeiro a agosto de 2000

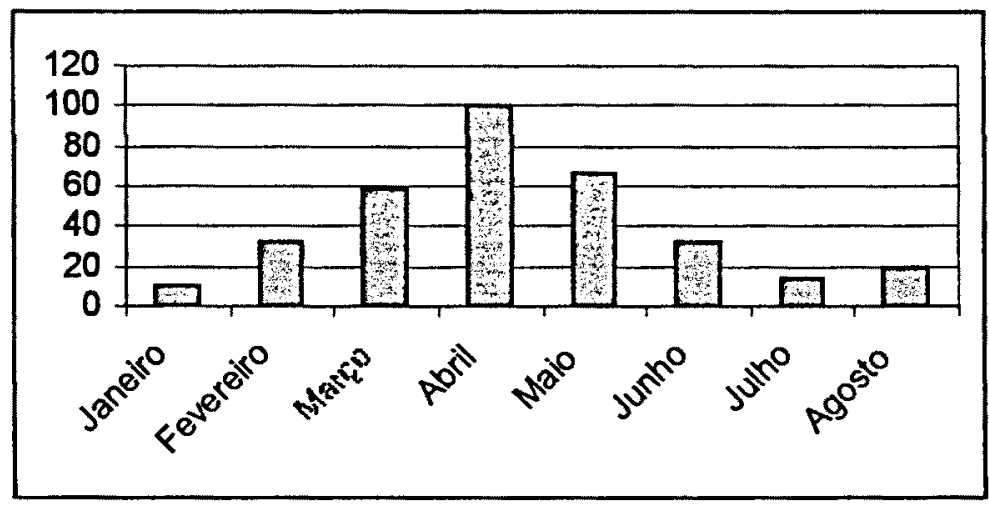

Fonte: Cartas da Frente, elaboração da autora, 2002

\footnotetext{
${ }^{17}$ A Lei limita a 9 meses a permanência na Frente de Trabalho para que não seja estabelecido vínculo empregatício.
} 
Inicialmente, foi possivel observar dois blocos de cartas: as de autoria de frentistas, $78 \%$, e de autoria de não frentistas, $22 \%$, considerando frentista a pessoa que, na data da carta, estava inserida no PEAD e não frentista a pessoa que, na data da carta, não estava inserida no PEAD.

Gráfico 2: Distribuição das Cartas da Frente, do período de janeiro a agosto de 2000 , segundo autoria frentistas e não frentistas

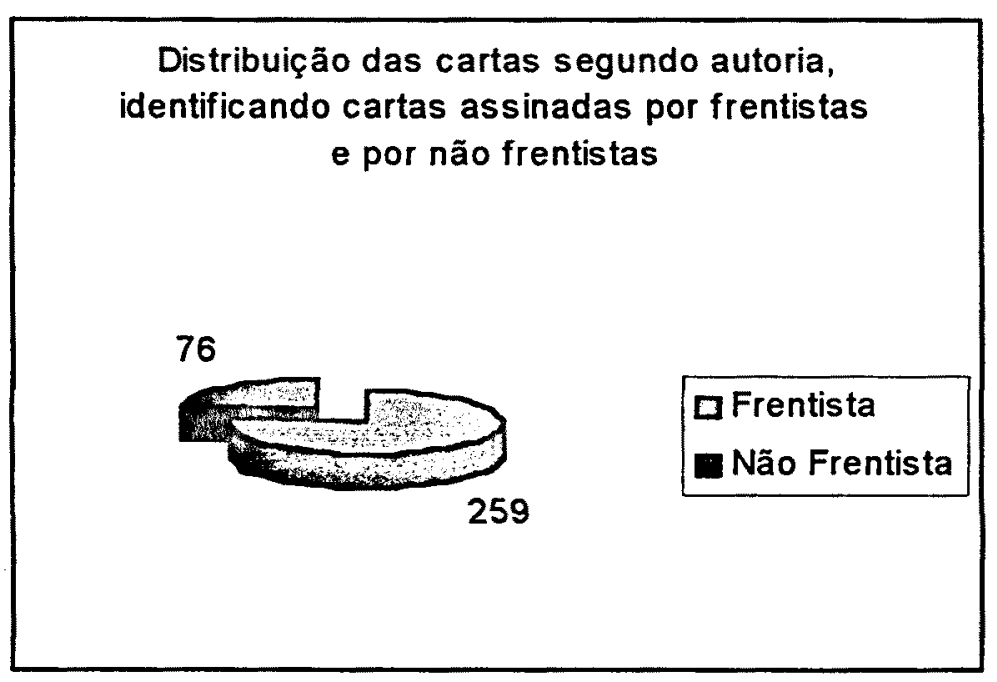

Fonte: Cartas da Frente, elaboração da autora, 2002

A maior parte $(93 \%)$ das cartas dos não frentistas pede lugar na Frente de Trabalho ${ }^{19}$, ou porque fez a inscrição e não foi selecionado, porque

18 As 76 cartas de autores não frentistas ou ex-frentistas são as seguintes: $2,3,5,6,11,12,16,24,27,33,34,35,36,40,42,47,52,53,57,60,63,66,116,123,128,130,146$, $150,152,154,168,192,194,195,204,213,215,216,219,226,229,230,232,234,235$. $237,243,250,254,257,261,290,296,300,301,308,310,311$, $312,313,314,315,319,320,321,322,327,335,337,338,340,342,345.346$

${ }^{19}$ As demais tecem comentários sobre o PEAD. 
ficou sabendo depois e deseja participar ou ainda, porque seu período na Frente terminou e ainda não arranjou emprego:

"por favor, me comunique, pois preciso muito trabalhar" (Carta $n^{\circ} 6$ )

"eu me ofereço a trabalhar de qualquer coisa" (Carta n ${ }^{\circ} 34$ )

"sou trabalhadeira" (Carta n²4)

"vendo as propagandas pela televisão e comentários gostaria de saber se é possivel de conseguir uma vaga de trabalho" (Carta $n^{\circ} 53$ ) "me de uma oportunidade deixe eu trabalhar nessa frente de trabalho" ( Carta n $\left.{ }^{\circ} 35\right)$

"estou cansada de andar e comprar jornais (...)estou com o diploma do $2^{\circ}$ grau e não consegui nada." (Carta ${ }^{\circ}{ }^{152)}$ "preciso trabalhar, meu marido está preso em Franco da Rocha (...) (Carta n ${ }^{\circ} 342$ )

"um trabalho que eu possa alimentar os meus filhos." (Carta $n^{\circ} 57$ )

"ou fazer um curso." ( Carta n60)

"faço bico para ajudar no orçamento, mas não estou conseguindo suprir minhas necessidades." (Carta $n^{\circ} 13$ )

"Assina uma pessoa desesperada para trabalhar" (Carta n $\left.{ }^{\circ} 60\right)$

Algumas cartas anexam curriculum vitae, informado a escolaridade (supletivo, $1^{\circ}$ e $2^{\circ}$ grau), habilidades como datilografia e computação $e$ empregos anteriores.

Esse discurso dos não-frentistas mostra como o PEAD é visto como uma oportunidade pelos cidadãos que estão desempregados $e$, de algum modo, tomam conhecimento das Frentes.

Essas cartas não foram utilizadas para compor o discurso do sujeito coletivo frentista, mas contribuíram para conformar o quadro em que o conjunto das manifestações se insere e também serão utilizadas na formulação das Conclusões.

Das 259 cartas assinadas por frentistas, quase a metade (49\%) manifesta agradecimento pelo PEAD e, outro tanto (46\%) pede prorrogação do tempo de vinculação ao Programa 
Gráfico 3: Freqüência percentual das solicitações, por tipo, nas Cartas da Frente, no periodo de janeiro a agosto de 2000

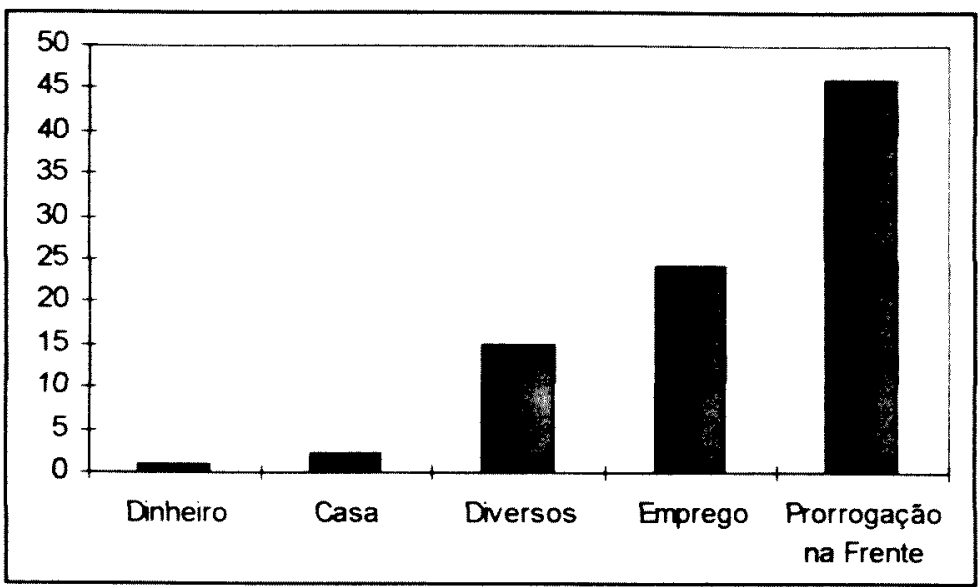

Fonte: Cartas da Frente, elaboração da autora. 2002

\subsection{0 processo de trabalho}

Enquanto expressão, o discurso do sujeito coletivo não é uma agregação discursiva de iguais "mas pedaços de diferentes discursos individuais que, pelo que se julga ser sua intercompatibilidade, permitem, como se fossem ingredientes agregáveis, compor um único "bolo discursivo." (LEFÈVRE e LEFÈVRE 2000, p.19).

Desse modo o discurso individual contido em cada carta foi analisado, Extraindo-se as idéias centrais e as expressões-chave. As idéias centrais são aquelas que, do ponto de vista do pesquisador, traduzem o essencial do conteúdo discursivo explicitado pelos sujeitos. Elas são vinculadas às expressões-chave, que são transcrições literais. Essas transcrições são identificadas ao final com o número da Carta de que foram extraídas.

$O$ discurso síntese do frentista como sujeito coletivo, construído dessa forma, foi apresentado na Introdução. Nos capítulos subseqüentes o 
processo é apresentado em detalhes, permitindo a visualização dos múltiplos discursos que emergem na composição das idéias centrais, pois, enquanto estratégia metodológica, o discurso do sujeito coletivo, visa a tornar mais clara uma dada representação social e o conjunto das representações capazes de conformar um dado imaginário, reconstruindo, "como em um quebra-cabeças, tantos discursos-síntese quantos se julgue necessário para expressar uma dada 'figura', ou seja, um dado pensar ou representação social sobre um fenômeno." (LEFÈVRE e LEFÈVRE 2000, p.19).

Está suposto nessa estratégia de análise que há uma pertença compartilhada em que "aquilo que poderia ter falado" seu "companheiro de coletividade atualizou por ele" (LEFÈVRE e LEFÈVRE 2000, p30), que permite "ouvir" "discursos que, a despeito de terem indivíduos na sua origem, são relativamente autônomos dos emissores individuais, na medida em que constituem produtos simbólicos de natureza coletiva que não são somas matemáticas de pensamentos de pessoas consideradas como unidades discretas equivalentes." (LEFÈVRE e LEFÈVRE 2000, p.33-34)

Porém, ao mesmo tempo, à medida em que o pesquisador recorta esses discursos, os analisa, encontra a paisagem comum, compõe os discursos, está, necessariamente, construindo uma leitura que é sua, desde o seu lugar social, com seus limites e possibilidades. 


\section{PARTE III}

\section{OS PERSONAGENS E \\ O PROGRAMA EMERGENCIAL DE AUXÍLIO DESEMPREGO}

O capítulo 6, primeiro dessa Parte III, é dedicado à caracterização do frentista, protagonista das Cartas da Frente e população focalizada pelo Programa Emergencial de Auxílio Desemprego - PEAD, implementado a partir de 1999, pela Secretaria do Emprego e das Relações de Trabalho, como parte da política pública destinada a combater a situação causada pelo desemprego. Busca identificar o "autor real", no dizer de FOUCAULT (2000, p.28) "esse homem que irrompe em meio a todas as palavras usadas, trazendo nelas seu gênio ou sua desordem."

Através das Cartas o frentista busca entabular um diálogo direto com o Governador do Estado ou com algum representante do Governo. Esse interlocutor, responsável pelas políticas públicas, revela seus objetivos na formulação do Programa Emergencial de Auxilio Desemprego. O Governo e o discurso oficial sobre o PEAD são focalizados no capítulo 7. 


\section{Capítulo 6 - O perfil do frentista}

O objetivo deste capítulo é apresentar os elementos que permitam situar os falantes em relação ao contexto em que elaboram e emitem seu discurso.

Em maio de $2000^{20}$ a direção do PEAD fez realizar uma pesquisa para verificar o perfil das familias tanto dos inscritos para o Programa como dos frentistas, isto é, daqueles que foram selecionados para integrar Frentes de Trabalho.

Essa pesquisa mostrou que as famílias PEAD (inscritos e frentistas) ${ }^{21}$ vivem em condições difíceis, moram mal e têm poucas oportunidades de bem estar. Alguns dos seus achados ajudam a configurar o quadro social dos frentistas, que é confirmado nas manifestações individuais das Cartas que compuseram o universo de pesquisa deste trabalho.

O quadro que se segue busca comparar os achados da pesquisa realizada pela Secretaria do Emprego e das Relações de Trabalho com as informações oferecidas pelos frentistas nas Cartas da Frente.

\footnotetext{
20 Pesquisa realizada no bojo do trabalho de assessoria da Fundap à SERT, que trabalhou com uma amostra da população PEAD, isto é, todas as pessoas que se inscreveram no Programa, e com uma amostra dos que, até a data da pesquisa, haviam sido engajados como frentistos em frentes de trabalho. Foram feitas 3.546 entrevistas sendo 1.718 com frentistas em atividade.
} 
Quadro 1: Comparativo do perfil dos frentistas segundo pesquisa realizada em 2000 e segundo o relato das cartas

\begin{tabular}{|c|c|}
\hline $\begin{array}{l}\text { Fonte: Relatório de Pesquisa, São } \\
\text { Paulo:SERT/FUNDAP, agosto de } \\
2000\end{array}$ & $\begin{array}{l}\text { Fonte: Cartas da Frente que } \\
\text { compõem o universo desta pesquisa }\end{array}$ \\
\hline $\begin{array}{l}\text { Os frentistas são chefes de família, } \\
\text { na } \\
\text { maioria mulheres (62\%), com mais } \\
\text { idade-um terço entre } 41 \text { e } 50 \text { anos }\end{array}$ & $\begin{array}{l}\text { "(...) porque já estou com } 46 \text { anos e } \\
\text { moro numa casa de favor. Tenho um } \\
\text { filho de } 13 \text { anos e eu quero ter } \\
\text { minha casa mesmo porque nesta } \\
\text { idade que estou é difícil arrumar } \\
\text { serviço." (Carta } n^{\circ} 8 \text { ) } \\
\text { "Aqui em casa eu sou pai e mãe de } \\
\text { meus filhos" (Carta } n^{\circ} 54 \text { ) }\end{array}$ \\
\hline $\begin{array}{l}\text { Com, em média, } 2 \text { anos e meio de } \\
\text { desemprego }\end{array}$ & \\
\hline $\begin{array}{l}51,5 \% \text { são migrantes de outros } \\
\text { Estados }\end{array}$ & $\begin{array}{l}\text { "(...) e a minha mãe tinha chegado a } \\
\text { pouco tempo do norte e não tinha } \\
\text { experiência de trabalho." (Carta } \\
n^{\circ} 62 \text { ) } \\
\text { "(..) viemos para São Paulo realizar } \\
\text { um sonho de uma vida melhor"(Carta } \\
n^{\circ} 9 \text { ) } \\
\text { "Eu sou um senhor que tenho } 38 \\
\text { anos e vim do nordeste no ano de } \\
1995 \text {. São cinco anos de luta para } \\
\text { conseguir um emprego e até agora } \\
\text { não consegui (...) (Carta n }{ }^{\circ} 60 \text { ) }\end{array}$ \\
\hline
\end{tabular}

${ }^{21}$ No momento da pesquisa haviam sido engajados às frentes 46.389 frentistas. 


\begin{tabular}{|c|c|}
\hline $\begin{array}{l}\text { Fonte: Relatório de Pesquisa, São } \\
\text { Paulo:SERT/FUNDAP, agosto de } \\
2000\end{array}$ & $\begin{array}{l}\text { Fonte: Cartas da Frente que } \\
\text { compõem o universo desta pesquisa }\end{array}$ \\
\hline $\begin{array}{l}\text { A renda média das familias dos } \\
\text { participantes do PEAD equivalia a } R \$ \\
264 \text {, sendo que metade das famílias } \\
\text { dispunha de renda inferior a } R \$ 151 \text {, } \\
\text { indicando que, para este segmento, a } \\
\text { bolsa oferecida pelo PEAD era a única } \\
\text { fonte de renda disponivel. Lembrando } \\
\text { que o salário mínimo no período da } \\
\text { pesquisa equivalia a } R \$ 151 \text {, observa-se } \\
\text { que } 69 \% \text { das famílias dos } \\
\text { participantes dispunham de, no } \\
\text { máximo, meio salário mínimo per } \\
\text { capita, }\end{array}$ & $\begin{array}{l}\text { "Estava sem nada em casa em } \\
\text { sentido material e com a cesta } \\
\text { básica e o salário de } 150 \text { reais já me } \\
\text { senti bem (...) Eu não tenho outra } \\
\text { renda a não ser esta da frente de } \\
\text { trabalho. (Carta n } 44 \text { ) }\end{array}$ \\
\hline $\begin{array}{l}\text { Mais da metade dos frentistas têm } \\
\text { apenas o ensino fundamental } \\
\text { incompleto } e \text {, antes do PEAD, poucos } \\
\text { haviam realizado algum curso ou } \\
\text { treinamento profissional }\end{array}$ & $\begin{array}{l}\text { "Por eu não ter estudo e a minha } \\
\text { carteira de trabalho estar há muito } \\
\text { tempo parada estava enfrentando } \\
\text { uma grande dificuldade em arrumar } \\
\left.\text { emprego" (Carta }{ }^{\circ} 46\right) . " \\
\text { "Tenho } 47 \text { anos de vida e também } \\
\text { pouca leitura. "(Carta } n^{\circ} 61 \text { ) }\end{array}$ \\
\hline
\end{tabular}




\begin{tabular}{|c|c|}
\hline $\begin{array}{l}\text { Fonte: Relatório de Pesquisa, São } \\
\text { Paulo:SERT/FUNDAP, agosto de } \\
2000\end{array}$ & $\begin{array}{l}\text { Fonte: Cartas da Frente que } \\
\text { compöem o universo desta } \\
\text { pesquisa }\end{array}$ \\
\hline $\begin{array}{l}\text { Quase a metade dos integrantes das } \\
\text { famílias têm menos de } 14 \text { anos. }\end{array}$ & $\begin{array}{l}\text { "(...) sou eu quem tenho que } \\
\text { sustentar a casa e meus filhos são } \\
\text { todos menores." (Carta n 64) } \\
\text { "(...) o meu companheiro teve um } \\
\text { derrame e eu sozinha para lutar com } \\
\text { ele e com meus quatro filhos, que } \\
\text { estão todos na escola e são menores } \\
\text { de quatorze anos (Carta } n^{\circ} 45 \text { ) }\end{array}$ \\
\hline $\begin{array}{l}\text { A taxa de dependência é bastante } \\
\text { alta. Cada pessoa que trabalha, deve } \\
\text { gerar renda suficiente para atender as } \\
\text { necessidades de consumo de } 2,41 \\
\text { pessoas } \\
\text { nivel de ocupação é baixo: atinge } \\
\text { quase } 60 \% \text { das pessoas até } 17 \text { anos } \\
\text { estão desempregadas e } 46 \% \text { na faixa } \\
\text { dos } 18 \text { aos } 24 \text { anos }\end{array}$ & $\begin{array}{l}\text { "(...) sou uma senhora viúva tenho } \\
26 \text { anos e duas filhas para criar e } \\
\text { estava sem trabalhar há algum } \\
\text { tempo. "(Carta } n^{\circ} 22 \text { ) } \\
\text { "Sou solteira tenho } 2 \text { filhas e minha } \\
\text { mãe com } 70 \text { anos e meu sobrinho } \\
\text { que é doente mental." (Carta } n^{\circ} 32 \text { ) }\end{array}$ \\
\hline
\end{tabular}




\begin{tabular}{|c|c|}
\hline $\begin{array}{l}\text { Fonte: Relatório de Pesquisa, São } \\
\text { Paulo:SERT/FUNDAP, agosto de } \\
2000\end{array}$ & $\begin{array}{l}\text { Fonte: Cartas da Frente que } \\
\text { compöem o universo desta pesquisa }\end{array}$ \\
\hline $\begin{array}{l}\text { Entre os participantes do Programa } \\
\text { predominam as situações de viuvez, } \\
\text { desquite/divórcio e separação não } \\
\text { judicial, evidenciando o peso destas } \\
\text { situações entre as mulheres }\end{array}$ & $\begin{array}{l}\text { (...) sou viúva e não tenho renda } \\
\text { nenhuma, eu queria trabalhar para } \\
\text { criar a minha filha, ela tem } 15 \text { anos } \\
\text { eu não tenho casa própria e tenho } \\
50 \text { anos. Minha família não me } \\
\text { ajuda em nada. " (Carta n' 11) } \\
\text { "Fui casada } 11 \text { anos mas } \\
\text { infelizmente meu casamento não deu } \\
\text { certo. Fiquei com dois filhos } \\
\text { deficientes para tratar" (Carta n' } \\
214 \text { ) } \\
\text { "Meu marido me deixou com os } \\
\text { meninos e desapareceu no mundo." } \\
\text { (Carta n' 102) }\end{array}$ \\
\hline $\begin{array}{l}\text { Poucas pessoas declararam ter outras } \\
\text { fontes para manter-se, como ajuda de } \\
\text { parentes ou seguro desemprego. }\end{array}$ & $\begin{array}{l}\text { "(...) sou casado tenho } 37 \text { anos } \\
\text { tenho } 3 \text { filhos. Já estav } \\
\text { desempregado há } 2 \text { anos e set } \\
\text { meses, as minhas condições de vid } \\
\text { estavam cada dia piores estav } \\
\text { contando com a ajuda de parentes. } \\
\left.\text { (Carta } n^{\circ} 17\right)\end{array}$ \\
\hline $\begin{array}{l}\text { A quase totalidade dos frentistas não } \\
\text { participa de qualquer tipo de } \\
\text { associação comunitária. }\end{array}$ & $\begin{array}{l}\text { "Sabe porque eu digo tudo isto } \\
\text { Porque eu já senti o que é chegar a } \\
\text { fundo do poço. Não ter esperança } \\
\text { no amanhã, sentir-se um Joã } \\
\text { Ninguém., Uma pessoa a mais n } \\
\text { multidão dos excluídos." (Cart } \\
\left.n^{\circ} 324\right)\end{array}$ \\
\hline
\end{tabular}




\begin{tabular}{|c|c|}
\hline $\begin{array}{l}\text { onte: Relatório de Pesquisa, São } \\
\text { aulo:SERT/FUNDAP, agosto de } \\
000\end{array}$ & $\begin{array}{l}\text { Fonte: Cartas da Frente que } \\
\text { compõem o universo desta pesquisa }\end{array}$ \\
\hline $\begin{array}{l}41 \% \text { dos domicílios possui até três } \\
\text { cômodos. } 16,2 \% \text { das moradias estão } \\
\text { situadas em favelas, índice bastante } \\
\text { superior aos } 9,1 \% \text { encontrado pela } \\
\text { Pesquisa de Condições de Vida (PCV- } \\
\text { SEADE) no ano de } 1998 \text {. }\end{array}$ & $\begin{array}{l}\text { (favela) não tenho quase nada" } \\
\left.\text { (Carta } n^{\circ} 92\right) \\
\text { Não tenho casa para morar, moro } \\
\text { em um barraquinho de madeira.(..) " } \\
\left.\text { (Carta } n^{\circ} 260\right) \\
\text { "Moro aqui aonde tem enchente, e } \\
\text { minhas coisas estão estragadas (...)" } \\
\left(\text { Carta }{ }^{\circ} 8\right)\end{array}$ \\
\hline ה רor pasos & $\begin{array}{l}4 \text { a } \\
\text { dade } \\
\text { D) }\end{array}$ \\
\hline
\end{tabular}

Os achados da pesquisa $e$ as cartas revelam que, oriundos da população desempregada da Região Metropolitana de São Paulo, os frentistas são chefes de família, muitos com idade de 41 a 50 anos, mulheres, com ensino fundamental incompleto. Poucos haviam realizado algum curso ou treinamento profissional antes do PEAD. Estavam há cerca de 2 anos e meio desempregados por ocasião de sua integração às Frentes de Trabalho.

Suas familias têm renda muito baixa. Metade vive apenas da bolsa da Frente de Trabalho. Cada pessoa que trabalha sustenta em média mais de duas pessoas. Metade dos integrantes das famílias 
dos frentistas tem menos de 14 anos. Assim, o nível de ocupação é baixo e a taxa de dependência é alta.

Os frentistas moram em sub-habitações. Muitos são migrantes e outro tanto está em situação de viuvez, separação ou abandono. Poucos dizem contar com ajuda de parentes e são também poucos que participam de associações comunitárias. São redes sociais esgarçadas, revelando baixa articulação social.

Essa situação que combina a ausência de integração no mundo do trabalho e a não inserção em redes de sociabilidade, segundo CASTEL (1991), faz as pessoas resvalarem para zonas de vulnerabilidade e lançamnas no processo de desafiliação social.

É desse lugar social e nessas condições de risco que vem o discurso do sujeito coletivo - frentista.

Capítulo 7 - 0 Governo do Estado de São Paulo e o PEAD

Mário Covas, personagem histórica da política nacional, tendo sido Prefeito do Município de São Paulo, exercido diversos mandatos parlamentares e tido papel de destaque na resistência democrática ao governo autoritário que se instalou durante quase vinte anos no País (19641982), exerceu dois mandatos como Governador eleito do Estado de São Paulo. O primeiro no período de 1995 a 1998 e o segundo iniciado em 1999 e interrompido com o seu falecimento em 2001. 
Walter Barelli foi Secretário do Emprego e das Relações de Trabalho do governo Covas. Sua história pública é vinculada ao movimento sindical e, particularmente, ao DIEESE - Departamento Intersindical de Estatística e Estudos Sócio-Econômicos,

O Programa de Auxílio Desemprego foi implementado a partir de 1999. pela Secretaria do Emprego e das Relações de Trabalho, durante o segundo mandato do Governador Mário Covas. Em março daquele ano, o Governo de São Paulo reuniu-se com entidades da sociedade civil para discutir iniciativas de geração de trabalho imediato, dentre as quais destacou-se a criação de Frentes de Trabalho (SERT, 2000) ${ }^{22}$.

As condições de desorganização financeira em que a gestão Covas encontrou o Estado de São Paulo teriam motivado a decisão do Governo em concentrar esforços para o chamado ajuste fiscal, que não fora, diz HAHN (1998, p.90), discutido como parte do programa de governo e tampouco participara, como concepção, do processo de planejamento estratégico que orientou as reuniões técnicas realizadas durante o período de transição entre a vitória eleitoral e a posse do novo governo.

$O$ Governo do Estado teve êxito no ajuste fiscal. $O$ déficit orçamentário era de $21,7 \%$ em 1994 e foi reduzido para 3,0\% em 1995 e caiu para zero no ano seguinte. Porém consumiu as energias do governo e obstaculizou o desenvolvimento do seu programa.

\footnotetext{
${ }^{22}$ Na edição de julho de 2000 de São Paulo na Frente pelo Trabalho - Transformando Crise em Crescimento, a data desse encontro é de 1995 e, na edição de novembro de 2000. a data é 1999. Walter Barelli esclareceu que o encontro ocorreu em 1999.
} 
A taxa de desemprego era de 19,3 em 1999 (Pesquisa de Emprego e Desemprego, SEADE-DIEESE), ano em que o PEAD - Programa Emergencial de Auxílio Desemprego foi iniciado, no segundo mandato do governo Covas.

Através da legislação que dá existência legal ao Programa e de documentos oficiais da Secretaria do Emprego e das Relações de Trabalho, conforme foi descrito na metodologia, é analisado o discurso do Governo sobre o PEAD, com o objetivo de apurar a compreensão sobre o PEAD, do ponto de vista oficial.

Essa parte da análise do discurso do Governo está dividida em temas. Para cada tema, foram identificadas as idéias centrais e as expressõeschave, indicando sua fonte.

Utiliza-se técnicas da mesma metodologia de construção do discurso do sujeito coletivo para decompor, desconstruir o discurso, no sentido de melhor compreendê-lo.

A escolha dos temas buscou constituir um corpo de análise que permitisse apreender os aspectos constitutivos do Programa em suas várias dimensões.

\subsection{0 que é o PEAD}

Quadro 2: Idéias centrais e expressões-chave sobre o que é O PEAD. segundo o discurso do Governo nos documentos oficiais. 


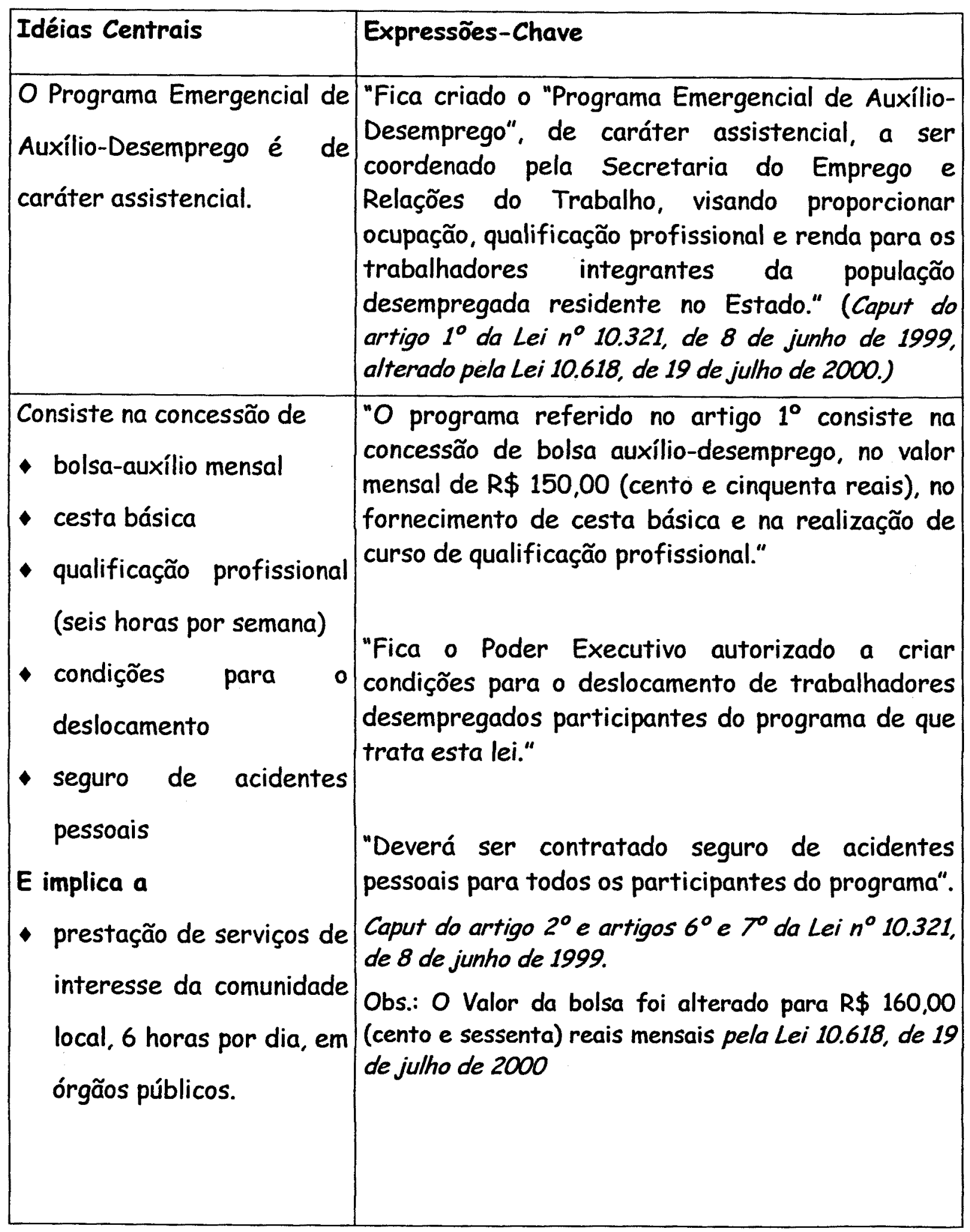




\begin{tabular}{|c|c|}
\hline Idéias Centrais & Expressões-Chave \\
\hline $\begin{array}{l}\text { O trabalho do frentista não } \\
\text { pode substituir servidores } \\
\text { ou empregados dos órgãos } \\
\text { públicos }\end{array}$ & $\begin{array}{l}\text { "Os órgãos da Administração direta e as } \\
\text { empresas em que o Estado detenha a maioria do } \\
\text { capital social somente poderão utilizar o } \\
\text { "Programa Emergencial de Auxílio-Desemprego" se } \\
\text { não promoverem a substituição de seus servidores } \\
\text { ou empregados, nem rotatividade de mão-de-obra, } \\
\text { em decorrência dos serviços prestados pelos } \\
\text { trabalhadores desempregados participantes do } \\
\text { referido programa." } \\
\text { Artigo } 5^{\circ} \text { da Lein }{ }^{\circ} 10.321 \text {, de } 8 \text { de junho de } 1999\end{array}$ \\
\hline $\begin{array}{l}\text { Eé de caráter } \\
\text { eventual }\end{array}$ & $\begin{array}{l}\text { "A participação no programa implica a colaboração, } \\
\text { em caráter eventual, com a prestação de serviços } \\
\text { de interesse da comunidade local, do município ou } \\
\text { com órgãos públicos (...) da Administração Pública } \\
\text { direta ou indireta, sem vínculo de subordinação e } \\
\text { sem comprometimento das atividades já } \\
\text { desenvolvidas por esses órgãos." } \\
\text { Caput do artigo } 4^{\circ} \text { da Lei op.cit. }\end{array}$ \\
\hline $\begin{array}{l}\text { participante pode ser } \\
\text { desligado se não cumprir as } \\
\text { regras e } \\
\text { - deixar de comparecer às } \\
\text { atividades que lhe foram } \\
\text { designadas } \\
\text { faltar ao curso de } \\
\text { qualificação. }\end{array}$ & $\begin{array}{l}\text { "O bolsista ser excluído do Programa nas } \\
\text { seguintes hipóteses: } \\
\text { I quando convocado após seleção não se } \\
\text { apresentar para início das atividades: } \\
\text { II quando não observar as normas estabelecidas } \\
\text { pela Administração: } \\
\text { III quando ausentar-se ou não comparecer } \\
\text { injustificadamente às atividades que lhe forem } \\
\text { designadas por } 5 \text { (cinco) dias corridos ou } 10 \text { (dez) } \\
\text { dias intercalados; } \\
\text { IV quando deixar de comparecer } \\
\text { injustificadamente ao curso de qualificação por } 2 \\
\text { (duas) vezes durante o mesmo mês; } \\
V \text { quando adotar comportamento inadequado ao }\end{array}$ \\
\hline
\end{tabular}




\begin{tabular}{|c|c|}
\hline Idéias Centrais & Expressões-Chave \\
\hline & $\begin{array}{l}\text { funcionamento do Programa." } \\
\text { Artigo } 12 \text { do Decreto n } 44.034 \text {, de } 8 \text { de junho de } 1999\end{array}$ \\
\hline $\begin{array}{l}\text { A participação no Pead não } \\
\text { representa } \\
\text { empregatício. }\end{array}$ & $\begin{array}{l}\text { "A participação no Programa Emergencial de } \\
\text { Auxílio-Desemprego não representa, em hipótese } \\
\text { alguma, vínculo empregatício, eis que de caráter } \\
\text { assistencial e de formação profissional, não se } \\
\text { revestindo das características que configuram tal } \\
\text { vínculo." } \\
\text { Artigo } 9^{\circ} \text { do Decreto } n^{\circ} 44.034 \text { de } 8 \text { de junho de } 1999\end{array}$ \\
\hline $\begin{array}{l}\text { O PEAD é um programa } \\
\text { social. }\end{array}$ & $\begin{array}{l}\text { "O Pead é essencialmente um programa social, } \\
\text { voltado para pessoas menos favorecidas, com } \\
\text { pouca escolaridade, mas com enorme potencial de } \\
\text { aprendizagem e força de vontade" } \\
\text { Uma construção em pleno vôo Frentes de Trabalho } \\
\text { Transformando crise em crescimento, São Paulo: } \\
\text { Governo do Estado, SERT, Folheto, sem data, sem } \\
\text { paginação }\end{array}$ \\
\hline $\begin{array}{l}\text { Não é idéia nova; não é } \\
\text { benesse do governo e não é } \\
\text { solução definitiva para o } \\
\text { problema do desemprego. }\end{array}$ & $\begin{array}{l}\text { "A idéia de organizar Frentes de Trabalho não é } \\
\text { nova e não é oferecida aqui nem como benesse do } \\
\text { governo nem como solução definitiva para o grave } \\
\text { problema do desemprego no Brasil." } \\
\text { Uma construção em pleno vôo - Idem, op cit }\end{array}$ \\
\hline
\end{tabular}

\subsection{População focalizada pelo PEAD}


Quadro 3: Idéias centrais e expressões-chave sobre a população focalizada pelo PEAD, segundo o discurso do Governo nos documentos oficiais.

\begin{tabular}{|c|c|}
\hline Idéias Centrais & Expressões-Chave \\
\hline $\begin{array}{l}\text { Focaliza trabalhadores } \\
\text { integrantes da população } \\
\text { desempregada residente no } \\
\text { Estado }\end{array}$ & $\begin{array}{l}\text { "Fica criado o "Programa Emergencial de Auxílio- } \\
\text { Desemprego" (...) visando a proporcionar } \\
\text { ocupação, qualificação profissional e renda para os } \\
\text { trabalhadores integrantes da população } \\
\text { desempregada residente no Estado." } \\
\text { Caput do artigo } 1^{\circ} \text { da Lei }{ }^{\circ} 10.321 \text {, de } 8 \text { de junho } \\
\text { de } 1999 \text {, alterado pela Lei } 10.618 \text {, de } 19 \text { de julho } \\
\text { de } 2000\end{array}$ \\
\hline $\begin{array}{l}\text { Dá preferência a pessoas } \\
\text { com: } \\
\text { - Maiores encargos } \\
\text { familiares } \\
\text { - Mulheres arrimo de } \\
\text { familia } \\
\text { Maior tempo de } \\
\text { desemprego } \\
\text { Maior idade }\end{array}$ & $\begin{array}{l}\text { "No caso do número de alistamentos superar o de } \\
\text { vagas, a preferência para a participação no } \\
\text { Programa será definida mediante aplicação, pela } \\
\text { ordem, dos seguintes critérios: } \\
\text { - Maiores encargos familiares } \\
\text { - Mulheres arrimo de família } \\
\text { - Maior tempo de desemprego } \\
\text { - Maior idade" } \\
\text { Artigo } 4^{\circ} \text { do Decreto } 44.034 \text {, de } 8 \text { de junho de } \\
1999\end{array}$ \\
\hline Sem exclusão & $\begin{array}{l}\text { "1.600 pessoas portadoras de deficiência já } \\
\text { encontraram trabalho nas Frentes." } \\
\text { São Paulo na Frente pelo Trabalho: transformando } \\
\text { crise em crescimento. Governo do Estado, SERT, } \\
\text { julho de } 2000(\mathrm{~s} / \mathrm{p})\end{array}$ \\
\hline
\end{tabular}




\begin{tabular}{|l|l|}
\hline Idéias Centrais & Expressões-Chave \\
\hline & $\begin{array}{l}\text { "1.194 pessoas egressas do sistema penitenciário } \\
\text { do Estado já encontraram trabalho nas Frentes." } \\
\text { Idem ibidem }\end{array}$ \\
\hline
\end{tabular}

\subsection{Objetivos do PEAD}

Quadro 4: Idéias centrais e expressões-chave sobre os objetivos do PEAD, segundo o discurso do Governo nos documentos oficiais.

\begin{tabular}{|c|c|}
\hline Idéias Centrais & Expressões-Chave \\
\hline $\begin{array}{l}\text { Intervir na situação dos } \\
\text { desempregados na Grande } \\
\text { São Paulo, busc'ando } \\
\text { provocar a ruptura do } \\
\text { movimento de exclusão. }\end{array}$ & $\begin{array}{l}\text { "O governo do Estado de São Paulo, nesse } \\
\text { contexto, decide intervir energicamente na bola } \\
\text { de neve em que se transformou o problema dos } \\
\text { desempregados na Grande São Paulo. Provocar uma } \\
\text { ruptura na cadeia formada pelo desemprego, fome, } \\
\text { violência e caos, que aparecem na esteira de cada } \\
\text { homem ou mulher chefes de familia } \\
\text { desempregados por mais de um ano, pode ser um } \\
\text { bom começo para reverter a direção dessa roda." } \\
\text { Programa de Qualificação Profissional nas Frentes } \\
\text { de Trabalho Documento-Base, SERT, junho de } \\
1999, \text { p. } 6\end{array}$ \\
\hline $\begin{array}{l}\text { Proporcionar ocupação, } \\
\text { qualificação profissional e } \\
\text { renda para os trabalhadores } \\
\text { integrantes da população } \\
\text { desempregada residente no } \\
\text { Estado. }\end{array}$ & $\begin{array}{l}\text { "Fica criado o "Programa Emergencial de Auxílio- } \\
\text { Desemprego" (...) visando proporcionar ocupação, } \\
\text { qualificação profissional e renda para os } \\
\text { trabalhadores integrantes da população } \\
\text { desempregada residente no Estado." } \\
\text { Caput do artigo } 1^{\circ} \text { da Lei }{ }^{\circ} 10.321 \text {, de } 8 \text { de junho } \\
\text { de } 1999 \text {, alterado pela Lei } 10.618 \text {, de } 19 \text { de julho } \\
\text { de } 2000\end{array}$ \\
\hline Trata-se da utilização da & "O que há de novo nas Frentes de Trab \\
\hline
\end{tabular}




\begin{tabular}{|l|l|}
\hline Idéias Centrais & Expressões-Chave \\
\hline $\begin{array}{l}\text { idéia de Frente de Trabalho } \\
\text { como instrumento efetivo } \\
\text { para reinserir o trabalhador } \\
\text { no mercado de trabalho. }\end{array}$ & $\begin{array}{l}\text { governo do Estado de São Paulo é o modo de pôr a } \\
\text { idéia prática e de fazer das Frentes } \\
\text { nemento efetivo para reinserir o trabalhador } \\
\text { Uma construção em pleno vôo op cit }\end{array}$ \\
\hline
\end{tabular}

\section{Estratégias do PEAD}

Quadro 5: Idéias centrais e expressões-chave sobre as estratégias do PEAD, segundo o discurso do Governo nos documentos oficiais.

\begin{tabular}{|c|c|}
\hline Idéias Centrais & Expressões-Chave \\
\hline \multirow[t]{2}{*}{$\begin{array}{l}\text { Proporcionar ocupação, } \\
\text { qualificação profissional e } \\
\text { renda para trabalhadores } \\
\text { desempregados. }\end{array}$} & $\begin{array}{l}\text { "Fica criado o "Programa Emergencial de Auxílio- } \\
\text { Desemprego" (...) visando proporcionar ocupação, } \\
\text { qualificação profissional e renda para os } \\
\text { trabalhadores integrantes da população } \\
\text { desempregada residente no Estado." } \\
\text { Caput do artigo } 1^{\circ} \text { da Lei no } 10.321 \text {, de } 8 \text { de junho } \\
\text { de } 1999 \text {, alterado pela Lei } 10.618 \text {, de } 19 \text { de julho } \\
\text { de } 2000\end{array}$ \\
\hline & $\begin{array}{l}\text { "Os benefícios de que trata o "caput" serão } \\
\text { concedidos pelo prazo de 6(seis) meses, } \\
\text { prorrogáveis em até } 3 \text { (três) meses." } \\
\text { Parágrafo único do artigo } 2^{\circ} \text { da Lei n }{ }^{\circ} 10.321 \text {, de } 8 \\
\text { de junho de } 1999 \text {, publicada no } 0.0 \text { E. n' } 107 \text {, } \\
\text { seção } I \text {, em } 8 / 6 / 1999\end{array}$ \\
\hline $\begin{array}{l}\text { A ocupação será através da } \\
\text { inserção em Frentes de } \\
\text { Trabalho no setor público }\end{array}$ & $\begin{array}{l}\text { "Todas as secretarias estaduais do governo de São } \\
\text { Paulo foram parceiras fundamentais, alocando os } \\
\text { bolsistas nas mais diversas atividades. Destacam- } \\
\text { se a Secretaria de Estado da Educação (SEE), que } \\
\text { abriu o maior número de Frentes de Trabalho no }\end{array}$ \\
\hline
\end{tabular}




\begin{tabular}{|c|c|}
\hline Idéias Centrais & Expressões-Chave \\
\hline & $\begin{array}{l}\text { âmbito do programa, além de Ter disponibilizado } \\
\text { suas } 2.200 \text { escolas para receber inscrições dos } \\
\text { interessados, seguida da Secretaria de Recursos } \\
\text { Hídricos, Saneamento e Obras (SRHSO), a } \\
\text { Secretaria da Segurança Pública (SSP)" } \\
\text { São Paulo na Frente pelo Trabalho: transformando } \\
\text { crise em crescimento. Governo do Estado, SERT, } \\
\text { julho de } 2000(\mathrm{~s} / \mathrm{p})\end{array}$ \\
\hline $\begin{array}{l}\text { Associando ocupação à } \\
\text { qualificação e à formação } \\
\text { profissional como forma de } \\
\text { abrir perspectivas e } \\
\text { instrumentalizar para } \\
\text { competir no mundo moderno. }\end{array}$ & $\begin{array}{l}\text { "Mas elas (as Frentes) tornam-se absolutamente } \\
\text { diferentes e inovadoras quanto associadas à } \\
\text { qualificação e à formação profissional. Abrem } \\
\text { perspectivas para o futuro e somam conhecimento, } \\
\text { algo indispensável para competir no mundo } \\
\text { moderno" } \\
\text { São Paulo na Frente pelo Trabalho: transformando } \\
\text { crise em crescimento. Governo do Estado, SERT, } \\
\text { julho de } 2000(\mathrm{~s} / \mathrm{p})\end{array}$ \\
\hline $\begin{array}{l}\text { Através do programa de } \\
\text { qualificação profissional } \\
\text { que visa a aumentar as } \\
\text { condições de } \\
\text { empregabilidade: } \\
\text { trabalhando a auto-estima } \\
\text { do frentista; } \\
\text { abrindo possibilidades de } \\
\text { contato entre trabalhadores } \\
\text { e instituições }\end{array}$ & $\begin{array}{l}\text { "Dada a sua característica de intervenção rápida, } \\
\text { o Programa de Qualificação Profissional das } \\
\text { Frentes de Trabalho não se propõe a formar } \\
\text { trabalhadores, até porque a própria prática que } \\
\text { eles vão desenvolver na tarefa diária já pressupõe } \\
\text { o que Paulo Freire chamava de "o saber de } \\
\text { experiência feito". O que se pretende, na } \\
\text { realidade, em primeiro lugar, é substituir a falta } \\
\text { de auto-estima surgida devido à ausência de } \\
\text { ocupação e renda por uma postura de } \\
\text { enfrentamento mais enérgico e de resultados mais } \\
\text { eficazes. Em segundo lugar, abrir possibilidades } \\
\text { de contato entre trabalhadores, empresas, } \\
\text { comunidade, entidades de formação, ONGs, órgãos }\end{array}$ \\
\hline
\end{tabular}




\begin{tabular}{|c|c|}
\hline Idéias Centrais & Expressões-Chave \\
\hline $\begin{array}{l}\text { abrindo espaços de debate e } \\
\text { troca de informações em } \\
\text { torno de temas de interesse } \\
\text { do trabalhador e do cidadão. }\end{array}$ & $\begin{array}{l}\text { públicos, sindicatos, de forma a possibilitar a } \\
\text { criação de novas oportunidades de trabalho. } \\
\text { Finalmente, pretende-se abrir espaços de debate } \\
\text { e troca de informações em torno de temas do } \\
\text { interesse do trabalhador em geral e, em última } \\
\text { análise, do cidadão, possibilitando que esses } \\
\text { bolsistas, após sua passagem pelas Frentes, } \\
\text { tenham aumentadas suas condições de } \\
\text { empregabilidade." } \\
\text { Programa de Qualificação Profissional nas Frentes } \\
\text { de Trabalho Documento-Base, SERT, junho de } \\
1999, \text { p. } 23\end{array}$ \\
\hline $\begin{array}{l}\text { Reconhecendo que a } \\
\text { estratégia de qualificação } \\
\text { não é suficiente para a } \\
\text { conquista de postos de } \\
\text { trabalho, o governo } \\
\text { aumentou o tempo das } \\
\text { bolsas por mais } 3 \text { meses }\end{array}$ & $\begin{array}{l}\text { "A procura por uma vaga de emprego continua } \\
\text { sendo tarefa árdua e angustiante para o } \\
\text { trabalhador de São Paulo, pois o número de vagas } \\
\text { disponiveis no mercado é insuficiente para atender } \\
\text { ao contingente de desempregados. O governo do } \\
\text { Estado de São Paulo, levando em conta os } \\
\text { obstáculos que o trabalhador encontra para obter } \\
\text { novo emprego, decidiu prorrogar por mais três } \\
\text { meses as Frentes de Trabalho, por meio do } \\
\text { Decreto n } 44.731 \text {, de } 28 \text { de fevereiro de } 2000 \text {. } \\
\text { "À medida que os contratos com os bolsistas vão } \\
\text { completando seis meses, são automaticamente } \\
\text { prorrogados por mais três." } \\
\text { São Paulo na Frente pelo Trabalho: transformando } \\
\text { crise em crescimento. Governo do Estado, SERT, } \\
\text { julho de } 2000 \text { (s/p) }\end{array}$ \\
\hline
\end{tabular}


75 Resultados esperados e obtidos pelo PEAD

Quadro 6: Idéias centrais e expressões-chave sobre os resultados esperados e obtidos pelo PEAD, segundo o discurso do Governo nos documentos oficiais.

\begin{tabular}{|c|c|}
\hline Idéias Centrais & Expressões-Chave \\
\hline 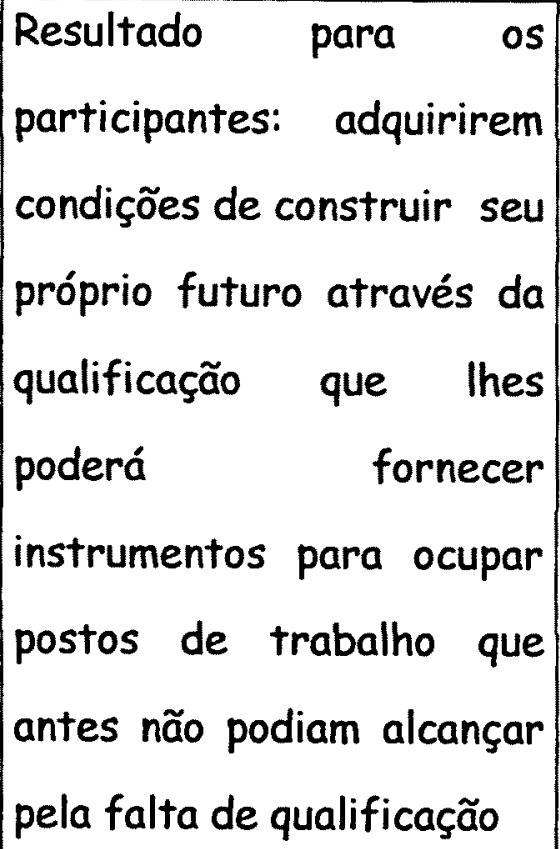 & $\begin{array}{l}\text { "Cada homem e cada mulher que freqüentam as } \\
\text { aulas de qualificação profissional abrem para si um } \\
\text { novo caminho que, seguramente, fornecerá } \\
\text { instrumentos para, com técnica e saber, ocupar } \\
\text { postos de trabalho que lhes eram negados pela } \\
\text { inexistência de qualificação." } \\
\text { "São Paulo cumprimenta cada um desses } \\
\text { trabalhadores que, com força e disposição, sem } \\
\text { preconceitos e sem temor do trabalho pesado, está } \\
\text { construindo o portal de seu próprio futuro." } \\
\text { São Paulo na Frente pelo Trabalho: transformando } \\
\text { crise em crescimento. Governo do Estado, SERT, } \\
\text { julho de } 2000(\mathrm{~s} / \mathrm{p})\end{array}$ \\
\hline $\begin{array}{l}\text { Resultado para a } \\
\text { comunidade: bem- estar } \\
\text { promovido pelo trabalho } \\
\text { dos frentistas em órgãos e } \\
\text { logradouros públicos. }\end{array}$ & $\begin{array}{l}\text { "Cada homem e cada mulher que, com seu trabalho } \\
\text { nas Frentes, limpam os trilhos dos subúrbios ou } \\
\text { parques, lavam e pintam muros } \\
\text { pichados, tratam da conservação de escolas e de } \\
\text { outros prédios de uso coletivo, contribuem } \\
\text { decisivamente para o bem-estar da comunidade." } \\
\text { Op. Cit. }\end{array}$ \\
\hline
\end{tabular}




\begin{tabular}{|c|c|}
\hline Idéias Centrais & Expressões-Chave \\
\hline $\begin{array}{l}\text { Contribuição ao serviço } \\
\text { público. }\end{array}$ & $\begin{array}{l}\text { "Os resultados acumulados permitem verificar que } \\
\text { foi a Secretaria de Estado da Educação que abriu o } \\
\text { maior número de Frentes de Trabalho no âmbito do } \\
\text { Pead, com participação de } 37,66 \% \text { no ranking das } 21 \\
\text { secretarias de estado parceiras do Programa. Em } \\
\text { segundo lugar, está a Secretaria de Recursos } \\
\text { Hídricos, Saneamento e Obras, com } 26,02 \% \text { e, em } \\
\text { terceiro lugar, a Secretaria da Segurança Pública, } \\
\text { com } 12,02 \% \text {. A participação dessas três secretarias } \\
\text { no total do Estado é de } 75,71 \% \text {." Op cit }\end{array}$ \\
\hline $\begin{array}{l}\text { Beneficia a comunidade por } \\
\text { gerar atividade e renda. }\end{array}$ & $\begin{array}{l}\text { "O Pead ao dar oportunidade de emprego e renda } \\
\text { aos bolsistas, está beneficiando a população como } \\
\text { um todo, uma vez que gera atividade e renda para } \\
\text { um contingente que abrange não apenas as famílias } \\
\text { desses bolsistas, como todos os envolvidos nos } \\
\text { serviços e atividades correlatas ao Programa, tais } \\
\text { como transporte, alimentação, qualificação } \\
\text { profissional, etc." } \\
\text { Op. Cit. }\end{array}$ \\
\hline $\begin{array}{lcr}\text { Beneficia } & \text { os } & \text { órgãos } \\
\text { públicos } & \text { parceiros do } \\
\text { Programa, } & \text { provocando } \\
\text { mudanças } & \text { proveitosas. }\end{array}$ & $\begin{array}{l}\text { "O Pead tem estimulado mudanças proveitosas } \\
\text { também nos órgãos parceiros: o Zoológico adaptou } \\
\text { instalações para deficientes e passou a aceitar } \\
\text { mulheres no seu ambiente de trabalho." } \\
\text { Op. Cit. }\end{array}$ \\
\hline
\end{tabular}

\subsection{Tipo de organização}

Quadro 7: Idéias centrais e expressões-chave sobre o tipo de organização com que foi implementado o PEAD, segundo o discurso do Governo nos documentos oficiais. 


\begin{tabular}{|c|c|}
\hline Idéias Centrais & Expressões-Chave \\
\hline $\begin{array}{l}\text { A implantação do PEAD é em } \\
\text { rede com outras } \\
\text { Secretarias, órgãos públicos } \\
\text { e organizações da sociedade } \\
\text { civil. }\end{array}$ & $\begin{array}{l}\text { "O Programa Emergencial de Auxílio Desemprego } \\
\text { - Pead será coordenado pela Secretaria do } \\
\text { Emprego e Relações do Trabalho, com a } \\
\text { colaboração das demais Secretarias de Estado e } \\
\text { participação das centrais sindicais, sindicatos, } \\
\text { sociedade amigos de Bairro, organizações não- } \\
\text { governamentais, representantes do Poder } \\
\text { Executivo local e da Comissão de Relações do } \\
\text { Trabalho da Assembléia Legislativa." } \\
\text { Artigo } 1^{\circ} \text { do Decreto n० } 44.034 \text {, de } 8 \text { de junho de } \\
1999 .\end{array}$ \\
\hline $\begin{array}{l}\text { Gerenciado de uma forma } \\
\text { inovadora, } \\
\text { contornar as barreiras de } \\
\text { gerenciamento existentes } \\
\text { no Estado. }\end{array}$ & $\begin{array}{l}\text { "Num Programa desse porte, o tempo tem peso } \\
\text { fundamental. Saber contornar todos os tipos de } \\
\text { barreiras de gerenciamento existentes no Estado } \\
\text { é um desafio. Concebido com base em um modelo } \\
\text { de gestão apoiado por parcerias e salas de } \\
\text { situação semanais - nas quais os problemas são } \\
\text { analisados e solucionados just-in-time - o PEAD } \\
\text { trabalhou num ritmo veloz, quebrando o } \\
\text { paradigma de um Estado lento e incapaz de } \\
\text { responder com efetividade a demandas sociais." } \\
\text { São Paulo na Frente pelo Trabalho: } \\
\text { transformando crise em crescimento. Governo do } \\
\text { Estado, SERT, julho de } 2000(\mathrm{~s} / \mathrm{p})\end{array}$ \\
\hline Real & $\begin{array}{l}\text { "Para levar adiante o Pead a SERT estabeleceu } \\
\text { parcerias institucionais indispensáveis para que } \\
\text { se alcançassem os objetivos do Programa. } \\
\text { Parceiros institucionais: } \\
\text { Fundação do Desenvolvimento Administrativo - } \\
\text { FUNDAP: Companhia Paulista de Processamento } \\
\text { de Dados, PRODESP: Companhia do } \\
\text { Metropolitano de São Paulo, METRÔ; Fundação } \\
\text { Sistema Estadual de Análise de Dados, SEADE; } \\
\text { Companhia de Seguros do Estado de São Paulo, } \\
\text { COSESP: Nossa Caixa, Nossa Banco; Entidades }\end{array}$ \\
\hline
\end{tabular}




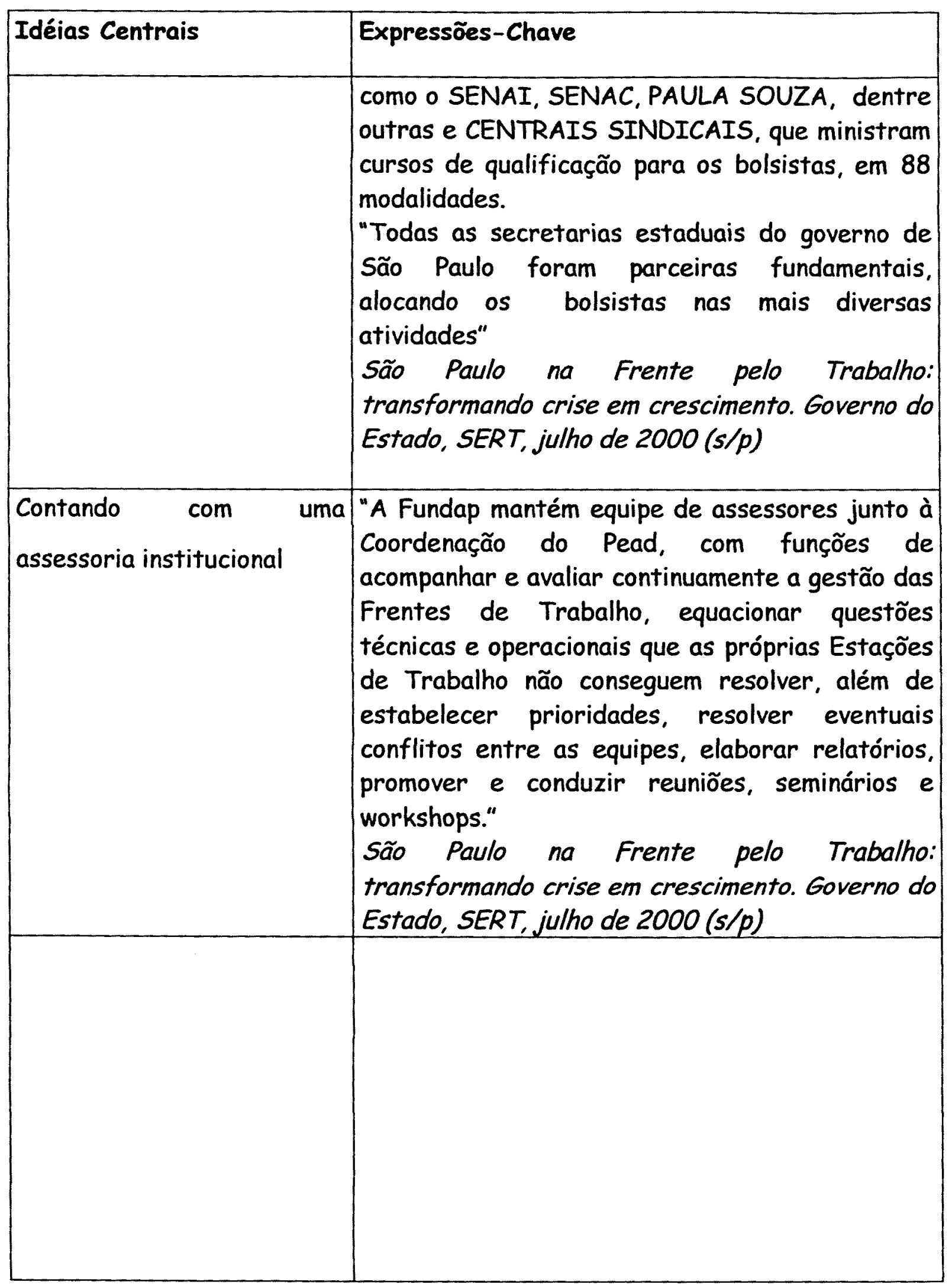




\begin{tabular}{|l|l|}
\hline Idéias Centrais & Expressões-Chave \\
\hline Com gerenciamento através & "Como parte da estratégia de gerenciamento, \\
foram constituídas nove Estações de Trabalho, \\
especializadas em diferentes assuntos e \\
prestadoras de atendimento direto e imediato ao \\
público solicitante." \\
"Estações de Trabalho que atuam junto à \\
Coordenação do Pead: Estação de contatos \\
institucionais; Estação de implantação e \\
acompanhamento: Estação de controle \\
operacional; Estação de Cesta Básica; Estação de \\
Finanças; Estação de Atendimento Especializado: \\
Estação de qualificação profissional; Estação \\
Assessoria de Imprensa: Estação de apoio \\
administrativo" \\
Op. Cit.
\end{tabular}

Assim, o Governo do Estado de São Paulo, em seu discurso oficial, diz que:

O Programa Emergencial de Auxílio-Desemprego é de caráter assistencial. É um programa social, que não pretende ser a solução definitiva para o problema do desemprego.

Focaliza trabalhadores integrantes da população desempregada residente no Estado, dando preferência a pessoas com: maiores encargos familiares; mulheres arrimo de família: maior tempo de desemprego: maior idade e sem exclusão de pessoas portadoras de deficiência e de ex-presidiários. 
$O$ objetivo do PEAD é proporcionar ocupação, qualificação profissional e renda para os trabalhadores integrantes da população desempregada residente no Estado, utilizando a idéia de Frente de Trabalho como instrumento efetivo para reinserir o trabalhador no mercado de trabalho. A ocupação, portanto, será através da inserção em Frentes de Trabalho no setor público.

A participação no Pead não representa vínculo empregatício. Consiste na bolsa-auxílio mensal; cesta básica: qualificação profissional (seis horas por semana); condições para o deslocamento e.seguro de acidentes pessoais. Implica a prestação de serviços de interesse da comunidade local, 6 horas por dia, em órgãos públicos da Administração direta $e$ indireta. Porém o trabalho do frentista não pode substituir servidores ou empregados dos órgãos públicos.

A estratégia do PEAD é associar ocupação, qualificação e formação profissional, durante 6 meses, como forma de abrir perspectivas, instrumentalizar para competir no mundo moderno e aumentar as condições de empregabilidade. Tempo ampliado, durante a primeira fase do programa, para 9 meses.

$O$ resultado esperado do Programa é que os participantes adquiram condições de construir seu próprio futuro através da qualificação que lhes poderá fornecer instrumentos para ocupar postos de trabalho que antes não podiam alcançar pela inexistência de qualificação adequada. 
O PEAD beneficia a comunidade por gerar atividade $e$ renda. Além disso, a comunidade está sendo beneficiada pelo próprio trabalho dos frentistas em órgãos e logradouros públicos.

Quanto à organização, O PEAD investe em um modelo inovador de gerenciamento, buscando contornar as barreiras de gerenciamento existentes no Estado. Investe na implantação em parceria com outros órgãos públicos e organizações da sociedade civil $e$, internamente, organiza-se por equipes.As inovações visam a conferir velocidade e ritmo à implantação do Programa, quebrando o paradigma de um Estado lento e incapaz de responder com efetividade a demandas sociais. 


\section{PARTE IV}

\section{OS DISCURSOS}

Todo processo de comunicação consiste em procurar ajustar, transformar o contexto compartilhado pelos parceiros, através da troca de mensagens (LEVY 1995). O texto das Cartas é naturalmente construído com essa intenção - transformar o contexto.

Um dos sujeitos é uma parcela da população originalmente imersa na espiral de perdas que caracteriza uma situação de exclusão social, foco do PEAD e nele inserida. $O$ outro sujeito é aquele que recebe delegação da sociedade para definir e desenvolver políticas públicas que contribuem ou respondem por condições de bem ou de mal estar da população.

Os sujeitos expressam através de discursos as representações sociais que os estruturam e que eles próprios estruturam, pois cada pessoa é, ao mesmo tempo, fonte e lago do seu meio ambiente ideológico, numa interação dialética. Por isso trabalha-se com o conceito de discurso como a associação de um texto ${ }^{23}$ a seu contexto (MAINGUENEAU 2000).

Esta parte é dedicada aos discursos que habitam as Cartas da Frente.

O capítulo 8 recupera o processo de construção do discurso do sujeito coletivo a partir das cartas dos frentistas.

\footnotetext{
${ }^{23} O$ texto é sequência linguística autônoma, oral ou escrita, produzida por um ou vários enunciadores numa situação de comunicação determinada (MAINGUENEAU 2000, p.140).
} 
O discurso do sujeito coletivo frentista foi construído com o encadeamento discursivo de idéias centrais identificadas $e$, ao mesmo tempo, espelhadas em conjuntos de expressões-chave, conforme a estratégia metodológica proposta por LEFÈVRE e LEFÈVRE (2000, p.21), trabalhando-se na sua formulação com "trechos selecionados literalmente dos depoimentos individuais" (LEFÈVRE e LEFÈVRE 2000, p.24).

O capítulo 9 trabalha o discurso do Governo tal como se manifesta, através de seus delegados, nas cartas-resposta às cartas dos frentistas.

Finalmente, o Capitulo 10 trabalha os termos do diálogo entre frentistas e governo tal como revelados nas Cartas.

\section{Capítulo 8 - O que diz o frentista}

Trabalhou-se com a manifestação desse sujeito que se apresenta dispersa em cartas escritas por indivíduos que pertencem ao grupo aqui chamado frentista, que compartilha um perfil que os caracteriza como população focalizada pelo PEAD.

No processo de análise das cartas, com a aplicação da metodologia do discurso do sujeito coletivo, as expressões-chave foram identificando dois conjuntos de idéias centrais - um deles que expressa a situação de perdas que os frentistas estavam vivendo antes ou durante a sua inserção no PEAD $e, 0$ outro, os ganhos que referem. Ambos os conjuntos pertencem a uma mesma espiral do movimento promoção-exclusão, que passa pela 
possibilidade de apropriação dos diferentes tipos de riquezas materiais $e$ imateriais que compõem a inserção social de uma pessoa ou de uma família.

\subsection{A espiral de perdas}

Através das cartas, as pessoas contam sobre fatos ou situações que deflagraram o processo de perdas em que se vêem ou se viam imersos. Nessa descrição, a falta de empregos é sempre citada só ou acompanhada de outros fatores agravantes para supera-la como a idade (desde os 17 até os 60), a inexperiência, o abandono, a viuvez ou separação, o distanciamento da rede social, deficiências, prisão, drogadição...

O quadro seguinte informa por onde começa a perda, na expressão dos frentistas.

Quadro 8 - Idéias centrais e expressões-cheve sobre os elementos deflagradores da espiral de perdas da população do PEAD, segundo as Cartas dos frentistas

\begin{tabular}{|l|l|}
\hline Idéias Centrais & Expressões-Chave e respectivas fontes \\
\hline $\begin{array}{l}\text { As portas do do "Estava desempregada há } 4 \text { anos e passando muita necessidade } \\
\text { fechadas }\end{array}$ & $\begin{array}{l}\text { estã três filhos pequenos e andava a procura, mas não encontrava } \\
\left.\text { nada." (Carta n }{ }^{\circ} 200\right) \\
\text { "(...) meu marido desde maio de } 93 \text { não trabalha registrado. } \\
\text { Vivemos de um bico aqui outro ali (...)tem dias que não sei mais o } \\
\left.\text { que fazer(...) (Carta n }{ }^{\circ} 311\right) \\
\text { "Meu marido faz bico quando encontra para fazer." (Carta n³40) }\end{array}$ \\
\hline
\end{tabular}




\begin{tabular}{|c|c|}
\hline Idéias Centrais & Expressões-Chave e respectivas fontes \\
\hline $\begin{array}{l}\text { A idade dificulta, } \\
\text { dos } 20 \text { aos } 60 \\
\text { anos }\end{array}$ & $\begin{array}{l}\text { "Senhor eu tenho } 60 \text { anos e não consegui me aposentar." (Carta } \\
\text { n75) } \\
\text { "Eu estou com } 50 \text { anos e as portas de emprego estão fechadas." } \\
\text { (Carta n80) } \\
\text { "Tenho } 56 \text { anos. Ah, Senhor Mário Covas, como é difícil uma } \\
\text { mulher desta idade arrumar serviço." (Carta n³12) } \\
\text { "Estou desempregada há } 3 \text { anos (...)Estou muito nervosa por estar } \\
\text { desempregada, não consigo emprego. Faço fichas em agências e só } \\
\text { prometem me chamar, ma não chama. Preciso ajudar minha mãe, } \\
\text { pois ela ganha pouco. Tenho } 17 \text { anos(...)Estou cursando o } 1^{\circ} \\
\text { colegial." (Carta n³14) } \\
\text { "(...)quero lhe pedir um emprego, não consigo arrumar, tenho } 43 \\
\text { anos, sempre trabalhei, mas agora por falta de emprego e também } \\
\text { por ter } 43 \text { anos as coisas ficam mais dificeis(...) fui dispensada da } \\
\text { empresa porque está quase falindo. Estou parada faz exatamente } \\
\text { um ano e três meses. Por favor, não aguento mais essa agonia. } \\
\text { Quero trabalhar para defender pelo menos o meu lar(..)." (Carta } \\
\left.n^{\circ} 319\right) \\
\text { "Eu tenho } 23 \text { anos e o pior estou desempregada há muito tempo(...) } \\
\text { (Carta n³21) }\end{array}$ \\
\hline $\begin{array}{l}\text { A inexperiência } \\
\text { também faz com } \\
\text { que seja mais } \\
\text { difícil arranjar } \\
\text { emprego }\end{array}$ & $\begin{array}{l}\text { (...) nós somos uma família pobre mas somos muito unidos, o meu } \\
\text { filho mais velho tem } 21 \text { anos, ele não bebe não fuma e nem tem } \\
\text { outros vícios mas ele não arranja emprego pois não tem carteira } \\
\text { registrada. Até agora ele trabalhou na agricultura viemos para } \\
\text { são Paulo realizar um sonho de uma vida melhor mas não } \\
\text { arrumamos emprego. tivemos de ir para o lixo fazer reciclagem } \\
\text { para sobreviver, um dia tinha e outro não. Tinha dia que agente } \\
\text { almoçava no outro não jantava." (Carta } n^{\circ} 9 \text { ) }\end{array}$ \\
\hline
\end{tabular}




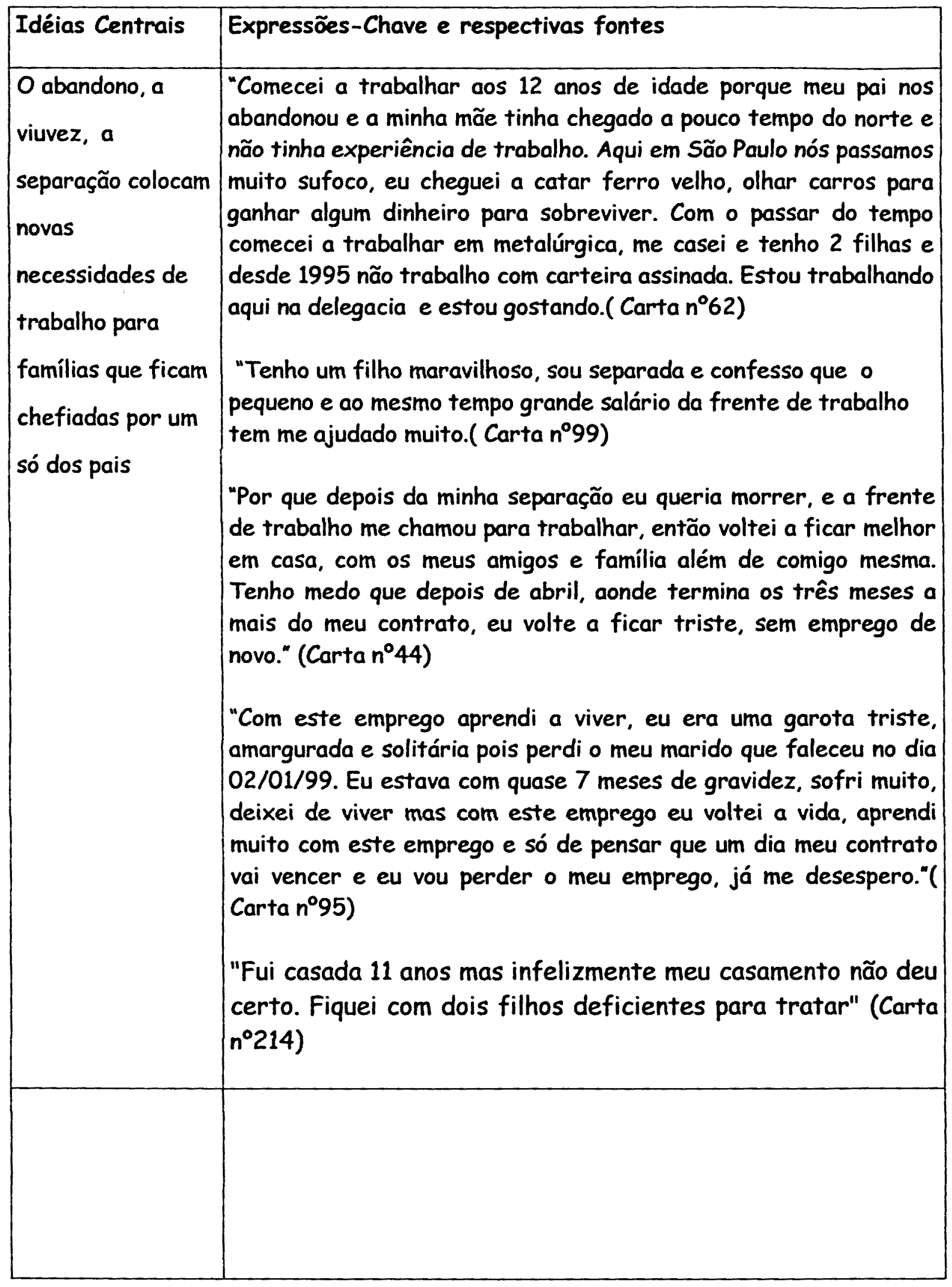




\begin{tabular}{|c|c|}
\hline ais & Expre \\
\hline $\begin{array}{l}\text { Qualquer } \\
\text { restrição agrava a } \\
\text { situação: } \\
\text { deficiências e } \\
\text { doenças na família } \\
\text { há um só tempo } \\
\text { causam restrições } \\
\text { a alguns de seus } \\
\text { membros e } \\
\text { colocam novas } \\
\text { demandas para } \\
\text { outros }\end{array}$ & 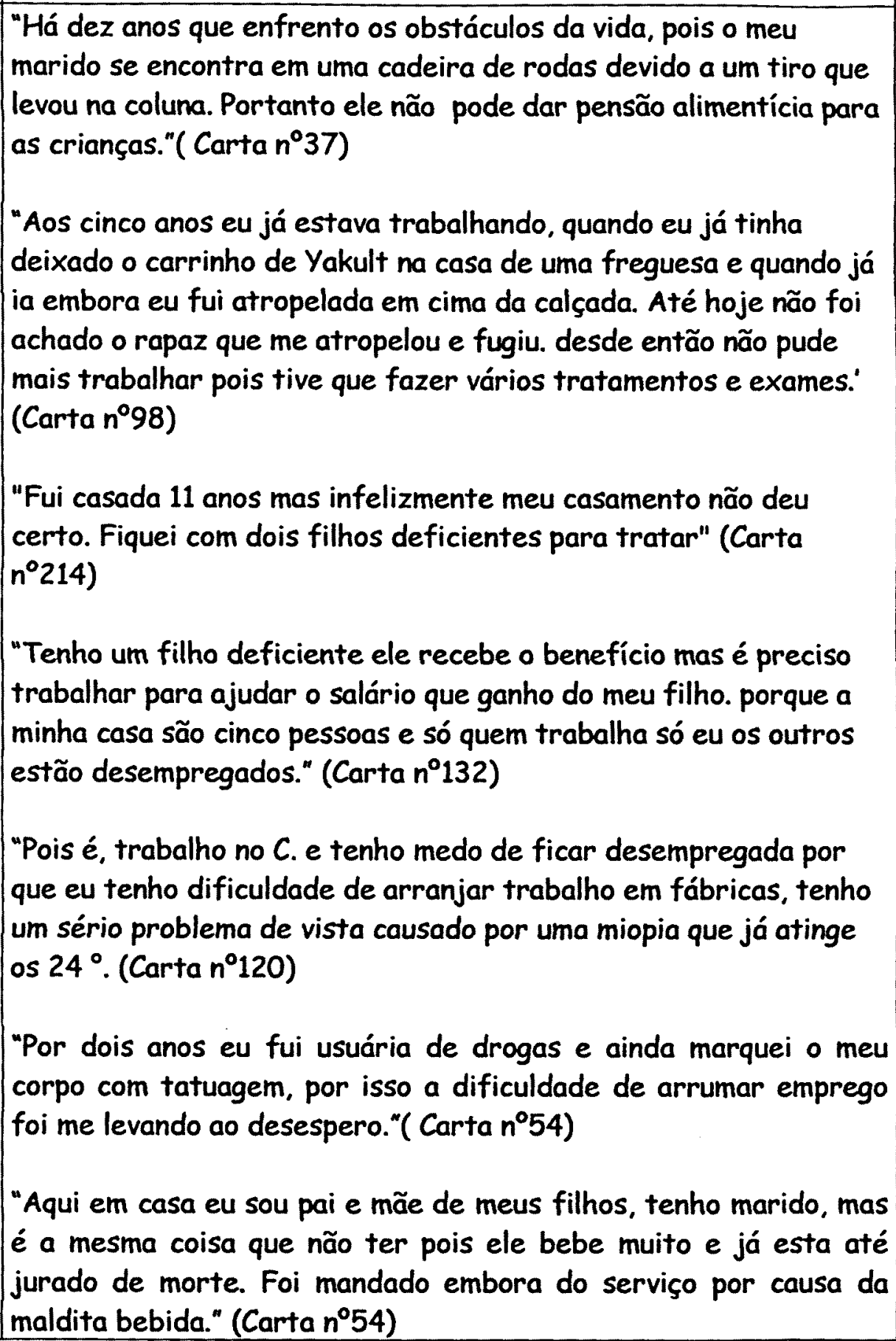 \\
\hline
\end{tabular}




\begin{tabular}{|c|c|}
\hline éias Centrais & Expressões-Chave e respectivas fontes \\
\hline $\begin{array}{l}\text { A condição de ex- } \\
\text { presidiário } \\
\text { dificulta a } \\
\text { obtenção de } \\
\text { emprego }\end{array}$ & $\begin{array}{l}\text { "No começo estávamos passando por muitas dificuldades, meu } \\
\text { esposo é um ex-presidiário e nunca teve uma chance na vida depois } \\
\text { que esteve preso, o senhor foi o único que confiou nele. E não se } \\
\text { decepcionou porque na escola em que ele trabalha todos gostam } \\
\text { dele e do serviço dele. (Carta n65) } \\
\text { "(...)porém sou um ex-presidiário e graças a deus, já paguei o que } \\
\text { devia a justiça, e como o senhor sabe fica difícil para nos que já } \\
\text { passamos por estes lugares um emprego fixo. "(Carta n²9) } \\
\text { "Me envolvi com pessoas erradas a oito anos atrás, e acabei por } \\
\text { cometer um delito pelo qual fui condenada pela justiça e cumpri } \\
\text { pena em regime fechado por três anos. Quando saí aos } 26 \text { anos de } \\
\text { idade tendo já os meus três filhinhos crescidinhos, quis muito não } \\
\text { errar mais e procurei melhores caminhos. Nestes caminhos não } \\
\text { achei emprego, sempre barrada pelos antecedentes criminais. Tive } \\
\text { que os deixar mais uma vez e tentar mantê-los mandando dinheiro } \\
\text { que conseguia trabalhando no Rio de Janeiro a } 600 \text { Km de distancia } \\
\text { e depois em Londrina que é mais distante um pouquinho, porque na } \\
\text { minha cidade não me deram uma chance." (Carta nº } 86 \text { ) }\end{array}$ \\
\hline $\begin{array}{l}\text { Também o } \\
\text { distanciamento da } \\
\text { rede social traz } \\
\text { dificuldades para } \\
\text { encontrar } \\
\text { trabalho. }\end{array}$ & $\begin{array}{l}\text { "(...) eu peço que me dê esta chance porque eu não tenho família } \\
\text { aqui em São Paulo pois eu sou de Belém do Pará. Eu sinto que a } \\
\text { minha vida mudou muito depois que comecei a trabalhar, depois de } \\
\text { muitos anos parada. Eu não tenho marido, sou só eu e minha filha } \\
\text { que tem } 12 \text { anos." (Carta n90) } \\
\text { "(...) viemos para São Paulo realizar um sonho de uma vida melhor } \\
\text { mas não arrumamos emprego. tivemos de ir para o lixo fazer } \\
\text { reciclagem para sobreviver, um dia tinha e outro não." (Carta n9) } \\
\text { "Aqui em São Paulo nós passamos muito sufoco, eu cheguei a catar } \\
\text { ferro velho, olhar carros para ganhar algum dinheiro para } \\
\text { sobreviver." (Carta n'62) } \\
\text { "(...) Eu sou um senhor que tenho } 38 \text { anos e vim do nordeste no ano } \\
\text { de 1995. São cinco anos de luta para conseguir um emprego e até }\end{array}$ \\
\hline
\end{tabular}




\begin{tabular}{|l|l|}
\hline Idéias Centrais & Expressões -Chave e respectivas fontes \\
\hline & $\begin{array}{l}\text { agora não consegui, pois bato nas portas das firmas e eles exigem } \\
\left.\text { um monte de documentos e no fim não sai nada.( Carta } n^{\circ} 60\right)\end{array}$ \\
\hline
\end{tabular}

Se o elemento deflagrador varia, muitos fatores são recorrentes até chegar à situação de fome, que ameaça a sobrevivência própria e dos dependentes e destrói a auto-estima.

Quadro 9 - Idéias centrais e expressões-chave sobre os elementos caracterizadores da desfiliação da população do PEAD, segundo as Cartas dos frentistas

\begin{tabular}{|c|c|}
\hline Idéias Centrais & Expressōes-Chave e respectivas fontes \\
\hline $\begin{array}{l}\text { Fome, necessidades, } \\
\text { humilhação }\end{array}$ & $\begin{array}{l}\text { "Não posso comprar nem um pão e leite para os meus filhos } \\
\text { porque estou desempregado. Se vocês não puderem me arrumar } \\
\text { esta vaga agora, peço a vocês que me doem pelo menos uma } \\
\text { cesta básica para a minha família não morrer de fome. Eu pago } \\
\text { duzentos reais de aluguel é já estou com três meses atrasado e } \\
\text { me encontro em uma situação difícil, com água e luz cortadas" } \\
\text { (Carta n¹50) } \\
\text { " (...) esta oportunidade da frente de trabalho foi para mim a } \\
\text { melhor coisa que aconteceu na minha vida, sou casado tenho } 37 \\
\text { anos e tenho } 3 \text { filhos. Já estava desempregado há } 2 \text { anos e sete } \\
\text { meses, as minhas condições de vida estavam cada dia piores } \\
\text { estava contando com a ajuda de parentes, realmente tudo isso } \\
\text { mudou minha vida." (Carta n¹7) } \\
\text { "Eu estava passando uma fase muito ruim na vida. Estava } \\
\text { passando até fome. Comia porque as pessoas me ajudavam. } \\
\text { Tenho um filho de } 3 \text { anos. Ele tem problemas de bronquite e } \\
\text { sempre ataca e os remédios são muito caros, nunca eu podia } \\
\text { comprar. (...) (Carta n²41) } \\
\text { "Na minha casa eu não tenho nem uma cama para dormir. Eu } \\
\text { durmo no colchão no chão, moro no barraco que nem cimento } \\
\text { tem no chão."(Carta n²41) }\end{array}$ \\
\hline
\end{tabular}




\begin{tabular}{|l|l|}
\hline Idéias Centrais & Expressões-Chave e respectivas fontes \\
\hline & $\begin{array}{l}\text { "(...) antes da Frente de Trabalho eu pedia esmola para dar de } \\
\text { comer aos meus filhos. Fui muito humilhada por tudo e por } \\
\text { todos. Não tenho casa para morar, moro em um barraquinho de } \\
\text { madeira.(..) Nunca tive ninguém para me ajudar, só Deus." } \\
\text { (Carta n²60) }\end{array}$ \\
\hline Perda da cidadania & $\begin{array}{l}\text { "(...) pois eu tinha perdido a minha cidadania e a minha vida não } \\
\text { tinha mais sentido, pois quando o homem perde o seu trabalho } \\
\text { ele se sente inútil e sem nenhum valor perante a sociedade, que } \\
\left.\text { com certeza irá discriminá-lo(...)"(Carta n }{ }^{\circ} 305\right)\end{array}$ \\
\hline
\end{tabular}

A angústia transborda das cartas quando as pessoas lembram a situação de risco social que estavam vivenciando antes da sua inserção na Frente de Trabalho e fica presente no medo de que, ao terminar o período, tudo se repita.

Porém o recheio da maioria das cartas é utilizado para contar sobre os ganhos.

\subsection{A ESPIRAL DE GANHOS}

Ao falar de ganhos, de riquezas, lembra-se logo de itens indispensáveis, como alimentos, teto, água, luz, material escolar, mas as cartas assinalam também a ceia de Natal e a bola da criança, os móveis, o tanquinho, a televisão e o ventilador, elementos de conforto doméstico, de composição do cenário de convívio dos indivíduos. Esse fato deve ser considerado pelos formuladores de programas que, muitas vezes, se 
reduzem à doação dos itens considerados indispensáveis por eles formuladores - em relação à população focalizada.

Gráfico 4: Distribuição percentual das Cartas da Frente segundo o tipo de benefício relatado

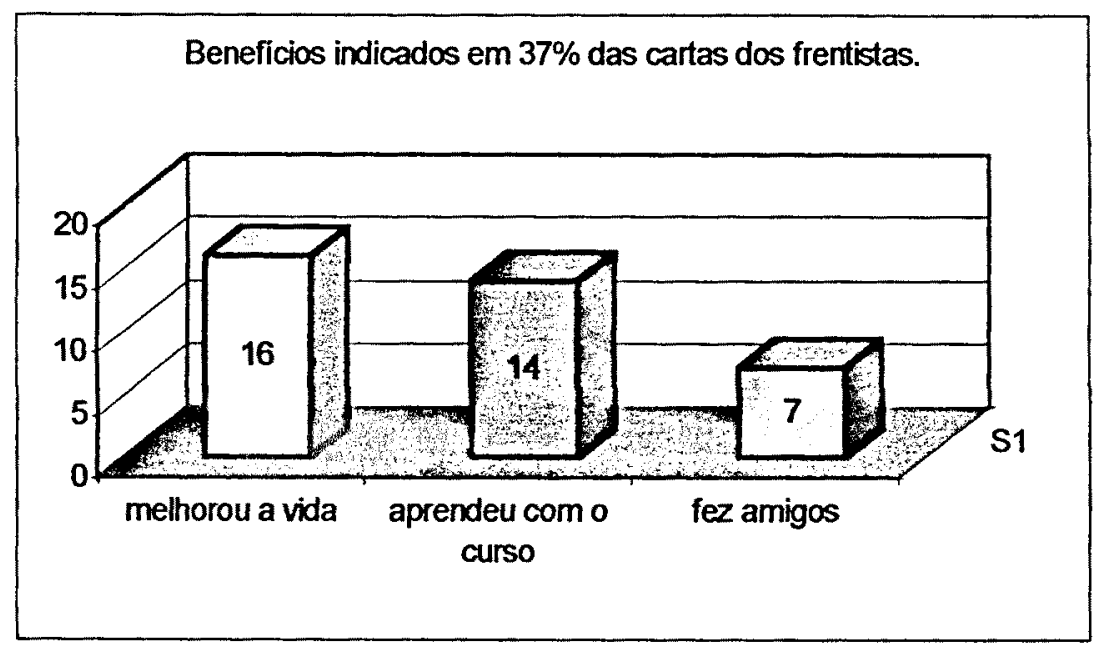

Fonte: Cartas da Frente, elaboração da autora, 2002

A indicação dos ganhos pelos autores das cartas, sugere que, se a espiral de perdas se dá a partir da perda do emprego, acompanhada ou seguida de outros fatores como o abandono, doença, a perda da rede social, a promoção, a inversão do movimento da espiral, ocorre pela aquisição de bens, pelo próprio exercício de atividades, pelo processo de aprendizagem, pelo resgate, de um lado, da autonomia $e$, de outro, da rede de relações sociais. 
Quadro 10- Idéias centrais e expressões-chave sobre os ganhos com a inserção no PEAD, segundo as Cartas dos frentistas

\begin{tabular}{|c|c|}
\hline Idéias Centrais & Expressões-Chave e respectivas fontes \\
\hline Ganhos materiais & $\begin{array}{l}\text { "E por isso que estou escrevendo esta carta, porque depois de } \\
\text { trabalhar na frente de trabalho a minha vida com os meus } \\
\text { cinco filhos melhorou muito. Eu gostaria de continuar neste } \\
\text { trabalho pois só assim eu posso dar a alegria para mim e para os } \\
\text { meus filhos de ter no fim do mês. Eu posso ter o direito de } \\
\text { comprar uma bola que eu não podia comprar." (Carta n58) } \\
\text { "Estou muito contente porque antes eu e meus filhos } \\
\text { passávamos muita necessidade, mas depois que comecei a } \\
\text { trabalhar na frente nunca mais faltou comida e nem material } \\
\text { escolar para os meus filhos. Sr governador sou eu quem tenho } \\
\text { que sustentar a casa e meus filhos são todos menores. Por } \\
\text { favor me dê uma chance não deixe esta frente acabar." (Carta } \\
n^{\circ} 64 \text { ) } \\
\text { "Eu estou muito satisfeita com esta frente de trabalho, ela } \\
\text { esta me servindo muito. Antes (...) eu estava desempregada e } \\
\text { quando vocês a criaram (a Frente), ela foi à solução dos meus } \\
\text { problemas, agora posso comprar o que eu preciso, não tudo, } \\
\text { mas o importante. Eu moro em terreno da prefeitura (favela) } \\
\text { não tenho quase nada, então eu queria que vocês me } \\
\text { efetivassem nesse emprego, porque eu necessito muito } \\
\text { trabalhar para comprar minhas coisas (rádio, tv, móveis etc...). } \\
\text { Também não só para comprar meus móveis mas para cuidar dos } \\
\text { meus filhos, porque quando eu era desempregada a vida era } \\
\text { difícil, agora é mais fácil porque já posso manter a casa."( Carta } \\
n^{\circ} 91 \text { ) }\end{array}$ \\
\hline
\end{tabular}




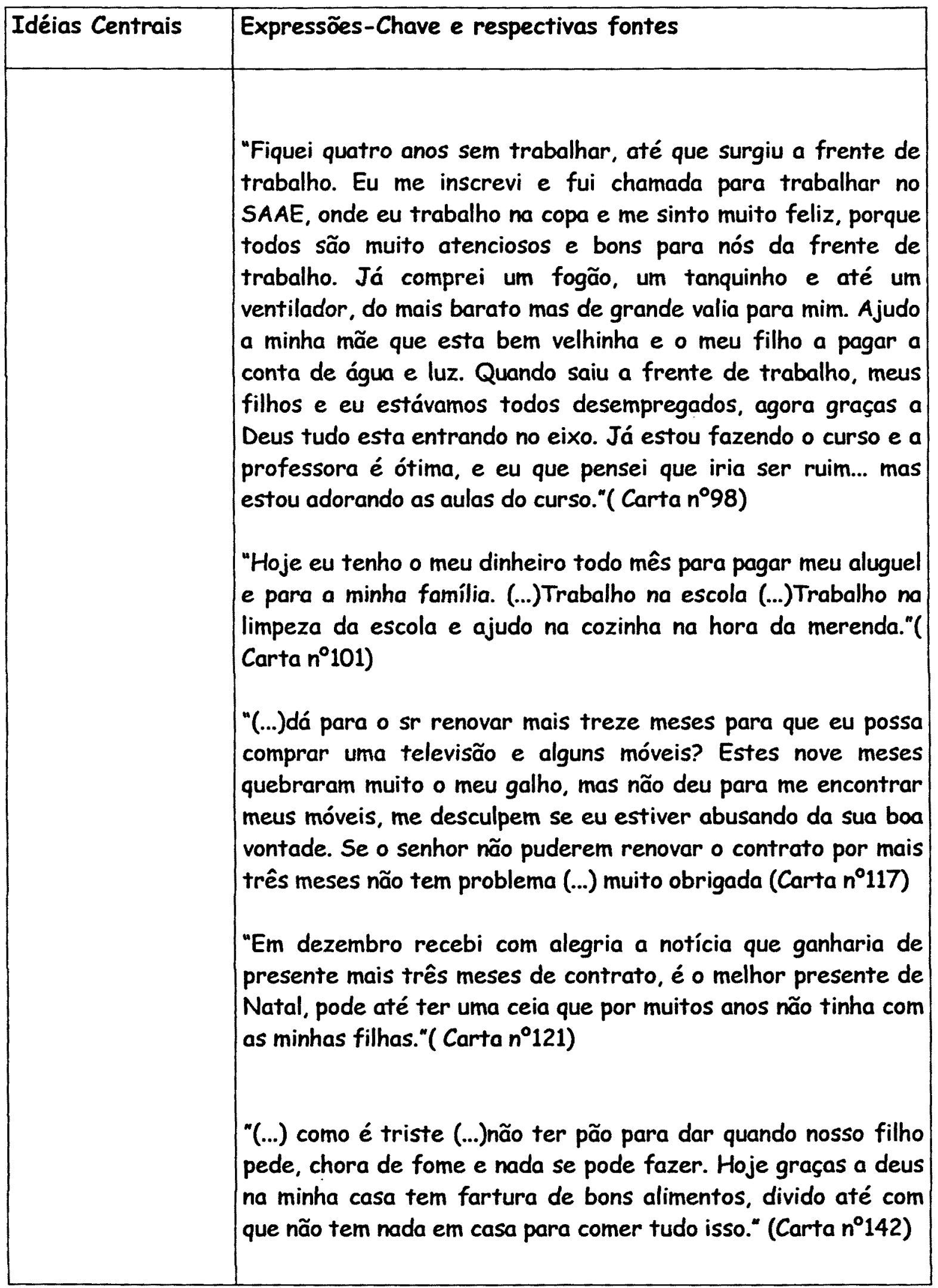




\begin{tabular}{|l|l|}
\hline Idéias Centrais & Expressões-Chave e respectivas fontes \\
\hline & $\begin{array}{l}\text { "Resumindo hoje já estou há oito meses na frente de trabalho, } \\
\text { estou me requalificando profissionalmente através de cursos } \\
\text { gratuitos oferecidos por este projeto, hoje também realizar } \\
\text { sonhos que sempre tive mas por motivos pessoais e financeiros } \\
\text { até então não podia realizá-lo que são os seguintes voltar a } \\
\text { estudar para adquirir mais conhecimento de tanto me faz falta } \\
\text { e graças a um dos cursos que fiz para a frente trabalho } \\
\text { finalmente pude aprender a mexer e a lidar com computador e } \\
\text { muitos reclamam e dizem que é pouco, os } \$ 150 \text { que ganham na } \\
\text { frente de trabalho são muito abençoados por deus pois através } \\
\text { desse dinheiro eu ajudo muito nas despesas mensais de minha } \\
\text { casa já comprei muitas coisas que sempre sonhei em que como } \\
\text { por exemplo minha televisão a cores e o tão sonhado } \\
\text { microondas. "(Carta n¹58) } \\
\text { "O senhor nem imagina o bem que esta frente de trabalho } \\
\text { trouxe para a minha familia, matou a nossa fome, não tenho } \\
\text { mais que ficar sem água por falta de pagamento, nunca recebi } \\
\text { uma cesta básica na minha vida, vim receber agora na frente de } \\
\text { trabalho." (Carta n²07) } \\
\text { "(...) e nós da frente de trabalho com um salário de 150 reaise } \\
\text { muito contentes com esse dinheiro, pois com esse salário e a } \\
\text { cesta básica que por sinal é ótima eu não passei necessidades } \\
\text { com meus filhos por nove meses."(Carta nº } 316)\end{array}$ \\
\hline
\end{tabular}




\begin{tabular}{|c|c|}
\hline léias Centrais & Expressões-Chave e respectivas fontes \\
\hline $\begin{array}{lrr}\text { Ganhos } & \text { pelo } \\
\text { trabalho em } & \text { si, } \\
\text { satisfação } & \text { por } \\
\text { realizar atividades }\end{array}$ & $\begin{array}{l}\text { "Venho por meio desta lhe agradecer pela oportunidade que deu } \\
\text { a mim e a outras pessoas desempregadas com a frente de } \\
\text { trabalho, eu há mais de dois anos que não consigo emprego e } \\
\text { atualmente estou em um colégio próximo a minha casa aonde } \\
\text { gosto de trabalhar, todos são ótimas pessoas a começar da } \\
\text { diretora e o colégio é um exemplo de limpeza, disciplina e } \\
\text { organização.(...)" (Carta n'10) } \\
\text { "Com esse emprego aprendi muito. O meu primeiro dia foi no } \\
\text { colégio, quando cheguei me mandaram limpar as salas de aula } \\
\text { deixamos a salas todas muito limpas para mim foi o melhor dia } \\
\text { da minha vida, porque eu descobri que tinha a minha vida muito } \\
\text { mais prazerosa, depois fomos carpinar a escola e depois } \\
\text { ajeitamos o jardim para plantar rosas e um pedaço para plantar } \\
\text { verduras, isso nos deu um valor enorme de vida e amor à } \\
\text { natureza. "(Carta n'17) } \\
\text { "Estava desempregada ha } 1 \text { ano e fiquei muito feliz quando } \\
\text { recebi o telegrama para trabalhar em um posto de saúde } \\
\text { próximo a minha casa. Sr. governador o senhor realizou um } \\
\text { sonho de infância meu que era trabalhar numa recepção." (Carta } \\
\text { n³2) } \\
\text { "Eu agradeço de coração por este emprego e por mais três } \\
\text { meses que nós vamos ter. Eu juro que foi a mesma coisa que eu } \\
\text { ter ganho na telesena, foi Deus que colocou o senhor no nosso } \\
\text { caminho para nos dar este emprego. Eu trabalho na parte dos } \\
\text { banheiros dos escritórios e faço o almoço. Gosto muito do que } \\
\text { faço e se tivesse mais serviço eu faria." (Carta n³8) } \\
\text { "No meu caso faço um pouco de tudo na escola, limpo as salas, } \\
\text { corredores, escadas e banheiros. Na troca de aulas ajo como } \\
\text { inspetora de alunos pois as crianças já se habituaram comigo. } \\
\text { Em aulas vagas fico com as crianças e na hora do intervalo } \\
\text { ajudo a merendeira." (Carta n51) }\end{array}$ \\
\hline
\end{tabular}




\begin{tabular}{|c|c|}
\hline Idéias Centrais & Expressões-Chave e respectivas fontes \\
\hline & 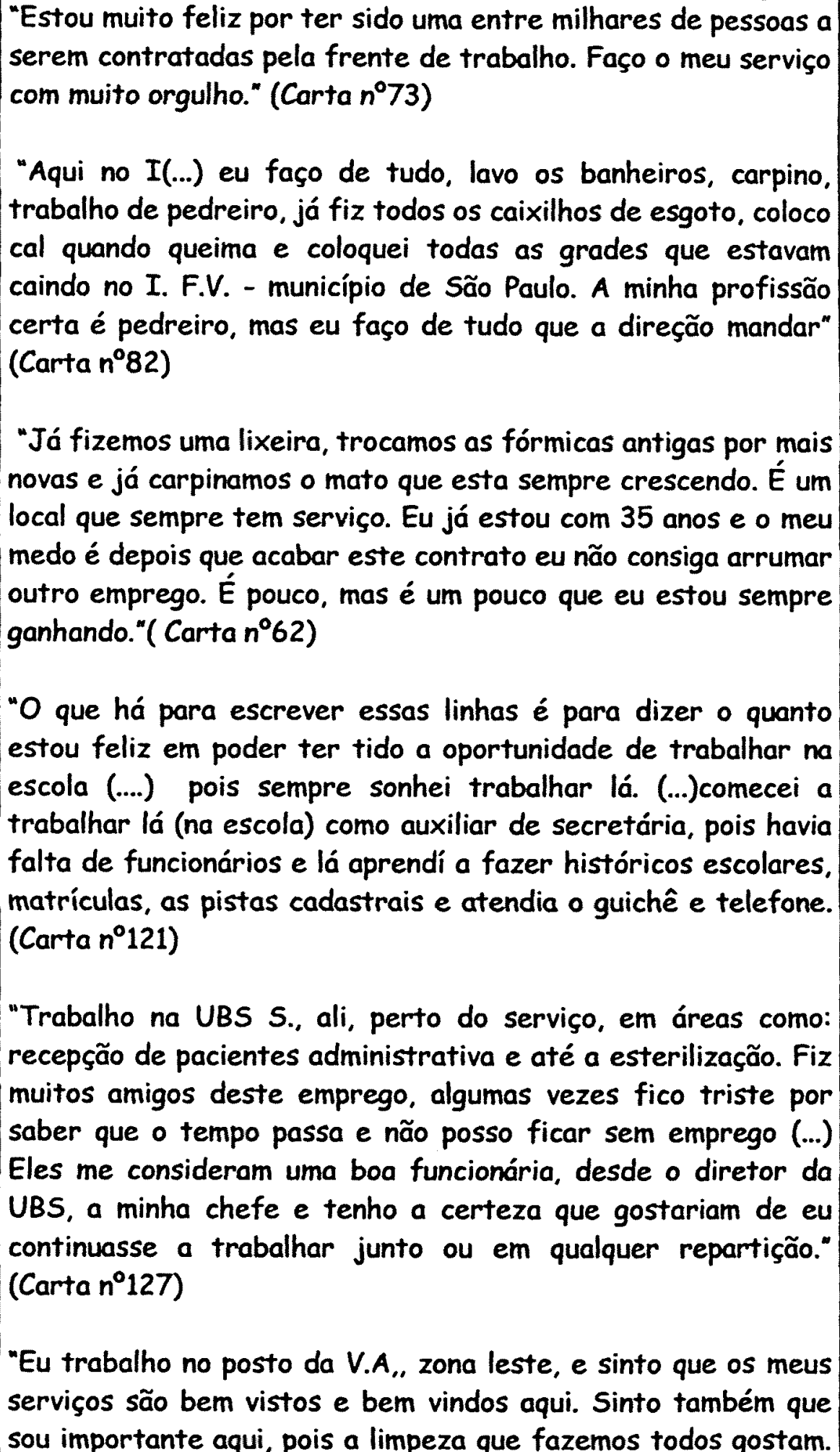 \\
\hline
\end{tabular}




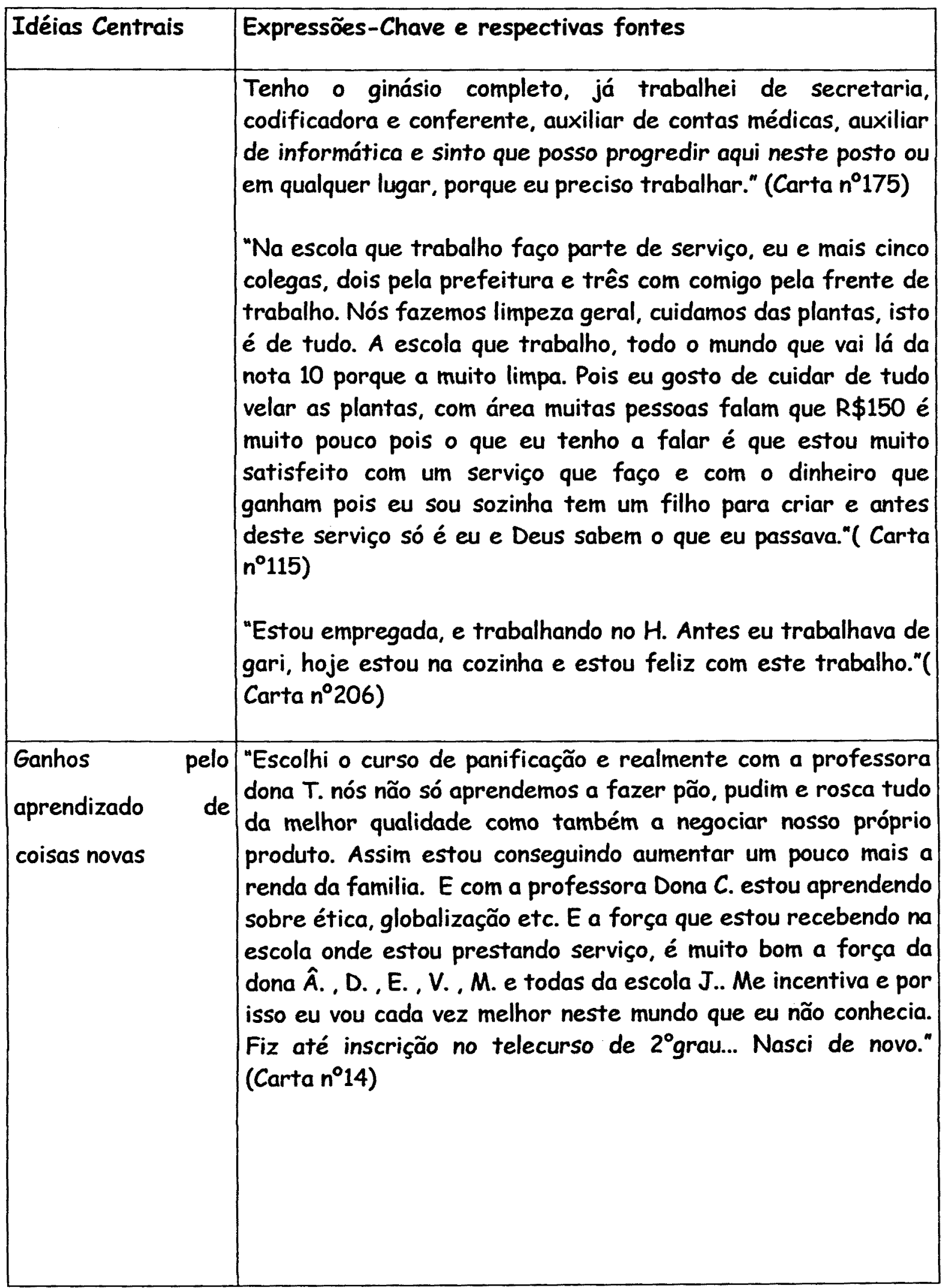




\begin{tabular}{|c|c|}
\hline Idéias Centrais & Expressões-Chave e respectivas fontes \\
\hline & $\begin{array}{l}\text { "Depois de tantas coisas que aconteceram na minha vida, me } \\
\text { deram também a oportunidade de me profissionalizar. Foi } \\
\text { quando nos deram as profissões as que nos colocarmos melhor, } \\
\text { achei que a de eletricista e encanador se colocavam no que eu } \\
\text { sempre quis fazer. Gostaria que muitas pessoas ai fora } \\
\text { conseguissem a oportunidade que eu consegui." (Carta n'17) } \\
\text { "Adorei o curso que fiz, conheci pessoas novas e principalmente } \\
\text { aprendi bastante."( Carta n'100) } \\
\text { "Fiz o curso de qualificação e optei por panificação que posso } \\
\text { trabalhar mesmo em casa. (Carta n'142) } \\
\text { "Além do mais estou fazendo curso de cabeleireira estou } \\
\text { adorando a oportunidade, pois não tive condições de comprar o } \\
\text { material para fazer estes cursos pelo C. e agora estou fazendo } \\
\text { o curso pela frente de trabalho e sem precisar comprar o } \\
\text { material, eles fornecem o material para que nós aprendamos. } \\
\text { (...)(Carta n'196) } \\
\text { "(...)porque quando eu sair da frentes de trabalho eu vou } \\
\text { ser uma manicure profissional se deus quiser (...) "(Carta } \\
n^{\circ} 133 \text { ) } \\
\text { "Esta sendo ótimo o curso, mesmo começando perto de acabar o } \\
\text { contrato, mas prolongou e eu agradeço para poder acabar o meu } \\
\text { curso de habilidades básicas. Este curso me fez sentir } \\
\text { adolescente e nunca é tarde para querer alcançar nossos } \\
\text { objetivos."( Carta n'191) }\end{array}$ \\
\hline
\end{tabular}




\begin{tabular}{|c|c|}
\hline Idéias Centrais & Expressões-Chave e respectivas fontes \\
\hline & $\begin{array}{l}\text { "Quanto aos cursos, também é uma ótima chance, eu optei por } \\
\text { copeira pois não havia de computação. Também prestei dois } \\
\text { concursos públicos para trabalhar em escolas, como tenho o } 1^{\circ} \\
\text { grau completo tentei. Estou aguardando o gabarito, alias } \\
\text { pretendo concluir o colegial quando der. Sabe minha auto } \\
\text { estima melhorou desde que comecei a trabalhar no colégio, mas } \\
\text { desanimo quando vou fazer alguma ficha em qualquer lugar e a } \\
\text { resposta é não, deveria ter uma lei obrigando estas empresas a } \\
\text { nos dar uma oportunidade." (Carta n'10) } \\
\text { "(...) este projeto foi um êxito muito grande na minha vida e em } \\
\text { outras vidas, que eu estava precisando, eu estava passando } \\
\text { fome. Hoje estou melhor em tudo graças a Deus e o senhor. } \\
\text { Estou gostando do Curso, está muito bom. Dia } 25 / 5 \text { fomos ver o } \\
\text { trabalho de pintor Sebastião Salgado no SESC Pompéia. Foi } \\
\text { muito gostoso." (Carta n³06) } \\
\text { "Gosto do que faço, pois adquiri muita aprendizagem e amizade } \\
\text { onde me encontro" (Carta n'336) } \\
\text { "Em primeiro lugar, boa noite que é a hora em que tive tempo } \\
\text { para escrever aos amigos funcionários da SERT para dizer que } \\
\text { estou muito feliz de ser mais uma das pessoas que fazem parte } \\
\text { da Frente de Trabalho. Estava há cinco anos desempregadas e } \\
\text { com seis filhos para dar educação, saúde e alimentação, estava } \\
\text { sendo muito difícil. Graças a este auxílio que tive de seis } \\
\text { meses estou muito bem, freqüento o curso no SENAI de (...) e } \\
\text { agora vamos começar a fazer o curso de doces e salgados, que } \\
\text { pretendo montar uma cantina e seguir a minha vida trabalhando } \\
\text { com meus filhos." (Carta n³49) }\end{array}$ \\
\hline
\end{tabular}




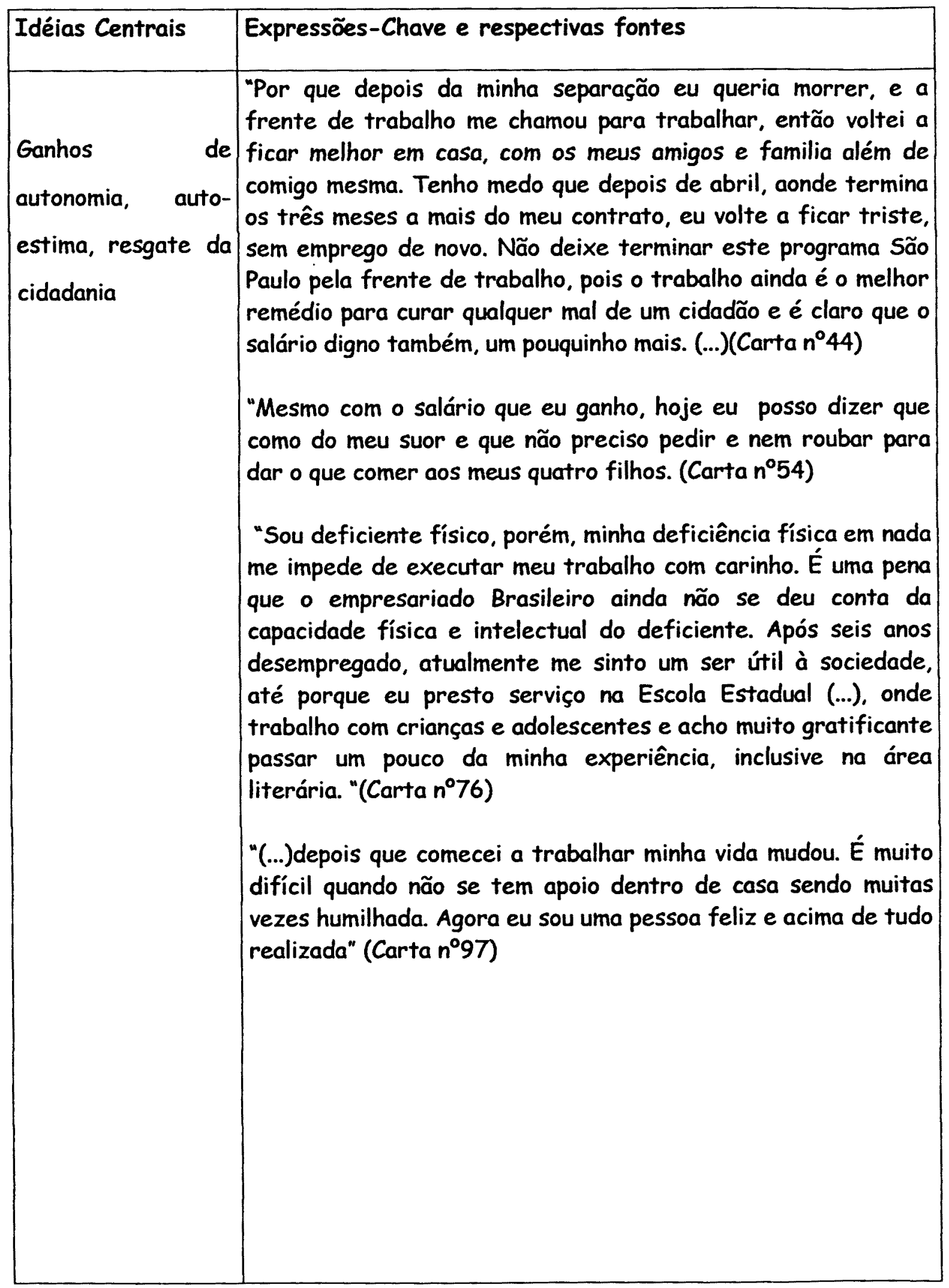




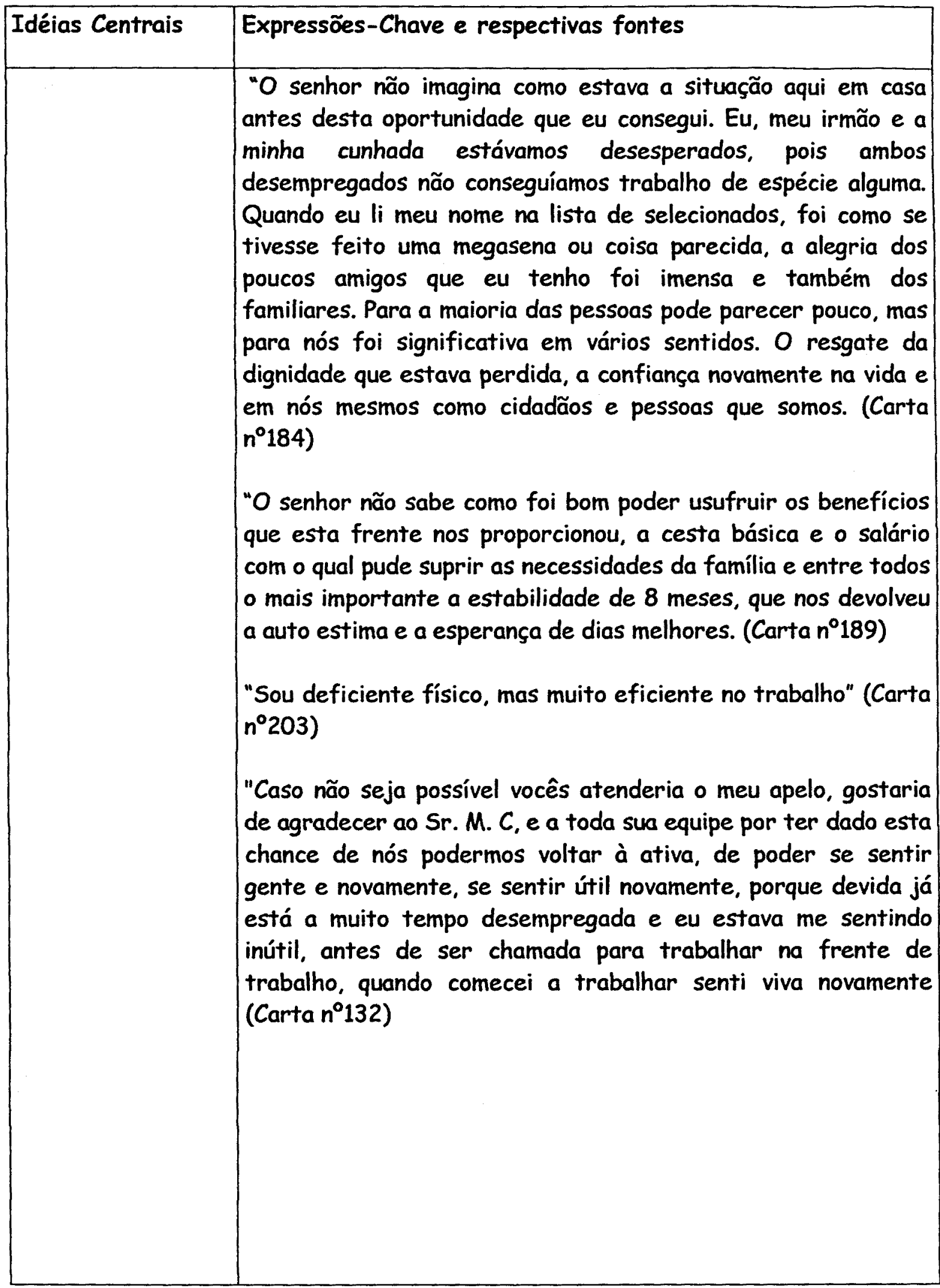




\begin{tabular}{|l|l|}
\hline Idéias Centrais & Expressões-Chave e respectivas fontes \\
\hline & $\begin{array}{l}\text { "Sou deficiente físico, porém, minha deficiência física em nada } \\
\text { me impede de executar meu trabalho com carinho. É uma pena } \\
\text { que o empresariado brasileiro ainda não se deu conta da } \\
\text { capacidade física e intelectual do deficiente. Após seis anos } \\
\text { desempregado, atualmente me sinto um ser útil à sociedade, } \\
\text { até porque eu presto serviço na E.E. (...), onde trabalho com } \\
\text { crianças e adolescentes e acho muito gratificante passar um } \\
\text { pouco da minha experiência, inclusive na área literária. } \\
\text { Precisamos incentivar os jovens a caminhar e buscar os } \\
\text { melhores caminhos da vida. Hoje estou muito feliz e tenho } \\
\text { absoluta certeza que Deus me deu um dom e um potencial que é } \\
\text { bem maior do que eu mesmo imaginava. Estou consciente e } \\
\text { acredito que posso me dar bem tanto na área da educação } \\
\text { quanto na área cultural."(Carta n76) } \\
\text { "(...) o senhor nunca me viu, não sabe quem sou eu, mas deu uma } \\
\text { coisa que eu acho que todo o ser humano quer - dignidade e } \\
\text { cidadania. Sabe porque eu digo tudo isto? Porque eu já senti o } \\
\text { que é chegar ao fundo do poço. Não ter esperança no amanhã, } \\
\text { sentir-se um João Ninguém., Uma pessoa a mais na multidão dos } \\
\text { excluidos." (Carta n³24) } \\
\text { "Tenho muita força de vontade e garra para trabalhar. } \\
\text { "(Carta n55) } \\
\text { "Eu considero esse meu trabalho muito agradável e com certeza } \\
\text { os meus amigos e amigas de trabalho são todos como uma } \\
\text { família que hoje vêem a vida muito melhor pelas boas } \\
\text { oportunidades oferecidas. Sou tão feliz como qualquer um ."( } \\
\text { Carta n¹7) }\end{array}$ \\
\hline $\begin{array}{l}\text { "Trabalhei na Escola Estadual (...).Entrei como servente e sai } \\
\text { como ajudante de inspetora. Amei aquelas crianças e elas } \\
\text { também me amaram, mas eu tive de sair para dar lugar a outras }\end{array}$ \\
\hline
\end{tabular}




\begin{tabular}{|c|c|}
\hline is & fontes \\
\hline $\begin{array}{ll}\text { Ganhos } & \text { de } \\
\text { relacionamento, } & \\
\text { reconstituição da } & \\
\text { rede social } & \end{array}$ & 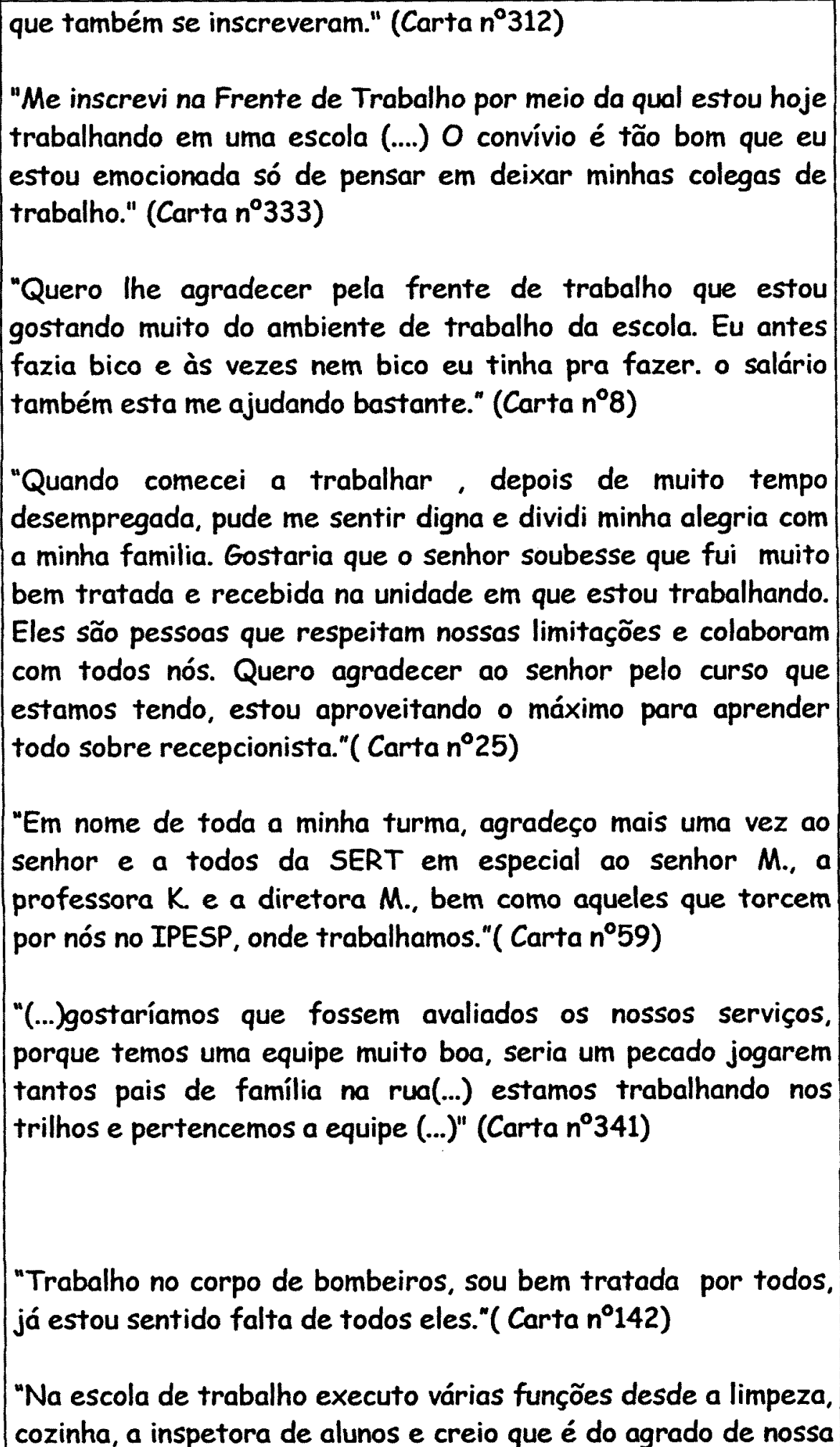 \\
\hline
\end{tabular}




\begin{tabular}{|c|c|}
\hline Idéias Centrais & Expressões-Chave e respectivas fontes \\
\hline & 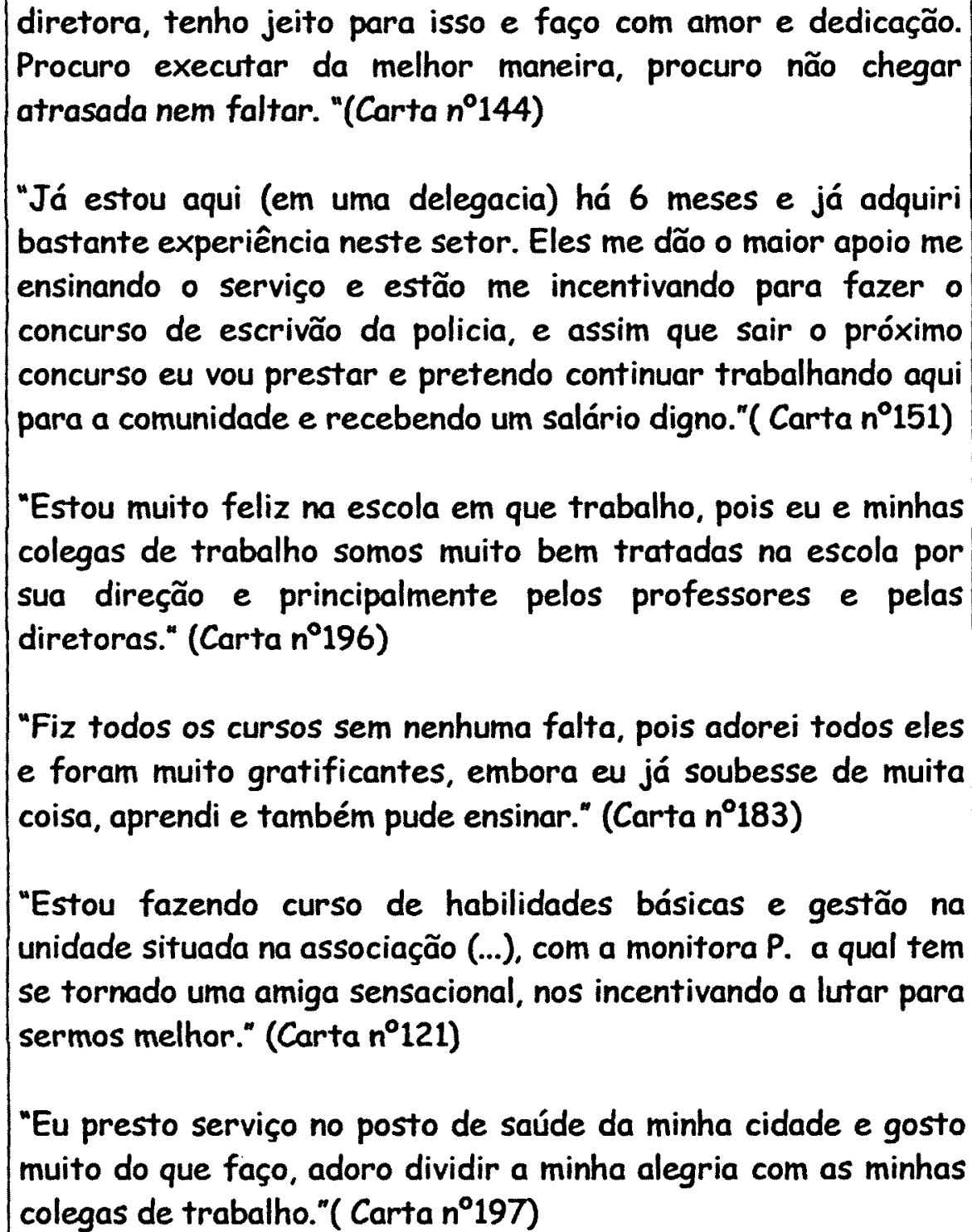 \\
\hline
\end{tabular}

Com exceção da alimentação, cuja frequiência de citação ressalta a precariedade da situação anterior, a promoção pela aquisição de bens materiais não é, afinal, o ganho mais salientado pelos missivistas. 
$O$ trabalho, a atividade em si, aparece como fundamental no resgate da condição de cidadão e do sentimento de inclusão. É evidente a importância que as atividades realizadas ganham no relato dos frentistas.

No campo dos ganhos também está a perspectiva de futuro, as esperanças que surgem com a aquisição de experiência e de conhecimentos. A proposta dos cursos oferecidos pelo PEAD é enfatizar a promoção da cidadania e, também, proporcionar ao frentista a aquisição de alguma habilidade que possa ser utilizada após a sua passagem pela Frente para o exercício de um trabalho remunerado ou rentável.

Para além de representar remuneração $e$, eventualmente, prazer no exercício de uma atividade, o trabalho significa o resgate da autonomia do indivíduo, da sua auto-estima e é visto, pelo frentista, como condição de cidadania.

E, finalmente, a valorização do ambiente de trabalho, ambiente escolar como oportunidades para tecer uma nova rede de relações. Fazer amigos representa a possibilidade de reconstituir os esgarçados laços da rede social dos indivíduos imersos em uma espiral de perdas. A perda de amigos, colegas de trabalho $e$, às vezes, da própria família, significa desamparo, não ter onde apoiar-se.

No trabalho é possivel fazer amigos. Amigos que são colegas de trabalho. Que têm histórias semelhantes e com os quais a comunicação se instaura no processo de fruição de um serviço prestado.

São várias as manifestações de frentistas que referem ter encontrado outros para dividir as tristezas e compartilhar alegrias. 


\subsection{A INSEGURANÇA EM RELAÇÃO À CURVA ASCENDENTE}

As cartas deixam clara a situação de perdas sucessivas em que se encontravam os missivistas e suas familias e ressaltam, sobretudo, aspectos que indicam a recuperação das condições de cidadania que a inserção na Frente de Trabalho representou nas suas vidas. Porém, é indispensável ter presente que a motivação da maioria das cartas é justamente preservar esse comecinho de movimento ascendente para não cair novamente na situação anterior, tão próxima ainda.

Quadro 11- Idéias centrais e expressões-chave sobre a insegurança quanto ao futuro após o desligamento do PEAD, segundo as Cartas dos frentistas

\begin{tabular}{|l|l|}
\hline Idéias Centrais & Expressões-Chave e respectivas fontes \\
\hline E depois? & $\begin{array}{l}\text { Quero em primeiro lugar parabenizar a todos os } \\
\text { envolvidos no programa da frente de trabalho, pois sei } \\
\text { que esta está ajudando muito a todos os beneficiados } \\
\text { neste programa. Saiba que eu sou uma destas pessoas e } \\
\text { estou muito feliz, mas paira a uma pergunta no ar que me } \\
\text { preocupa muito. E depois de tudo isso? (Carta n¹44) }\end{array}$ \\
\hline Como fazer para & $\begin{array}{l}\text { "No entanto, gostaria de ser efetivada, para ter mais } \\
\text { segurança, pois muitos acabaram o periodo de trabalho e } \\
\text { só Deus sabe o que pode acontecer com cada um de nós, } \\
\text { pois está difícil demais conseguir empregos."( Carta } \\
\left.n^{\circ} 328\right) \\
\text { " (...) por favor não quero ficar só } 6 \text { meses, me ajude a } \\
\text { ter um emprego certo porque eu quero trabalhar com }\end{array}$ \\
\hline
\end{tabular}




\begin{tabular}{|c|c|}
\hline Idéias Centrais & Expressōes-Chave e respectivas fontes \\
\hline & $\begin{array}{l}\text { dignidade. Eu nunca consegui assinar minha carteira } \\
\text { espero que vocês me entendam e me ajudem em nome do } \\
\left.\text { senhor Jesus. (...)"(Carta } n^{\circ} 22\right) \\
\text { "Porém sei que a frente de trabalho é só um contrato de } \\
\text { seis meses, mas eu já estou numa idade de } 42 \text { anos e } \\
\text { como o senhor secretário sabe fica dificil emprego"( } \\
\text { Carta } n^{\circ} 29 \text { ) } \\
\text { "Estou fazendo isso porque tenho certeza que no } \\
\text { término ficaremos todos sem emprego novamente. Fico } \\
\text { ansiosa porque tenho três filhos para criar que estão } \\
\left.\text { estudando."(Carta } n^{\circ} 48\right)\end{array}$ \\
\hline Temos medo & $\begin{array}{l}\text { "Estou trabalhando, mas com aquele medo de quando } \\
\text { acabar o contrato como eu vou fazer para arranjar um } \\
\text { emprego. Tenho medo de voltar tudo de novo."( Carta } \\
n^{\circ} 64 \text { ) } \\
\text { "Estou me sentindo útil outra vez, espero que o senhor } \\
\text { não acabe com a frente de trabalho, porque senão eu vou } \\
\text { sofrer de novo, o senhor sabe emprego esta difícil } \\
\text { principalmente para mim que já tenho } 49 \text { anos sou só e } \\
\text { tenho dois filhos menores para sustentar" (Carta n70) } \\
\text { "Senhor eu só imagino quando acabar este trabalho. } \\
\text { (...)Eu tenho uma filha de } 12 \text { anos que estuda e eu só } \\
\text { imagino quando chegar esta hora de eu ficar sem } \\
\text { emprego." (Carta n } 75 \text { ) } \\
\text { "Encarecidamente eu lhe peço um grande favor de me } \\
\text { ajudar, renovando o meu contrato da frente de trabalho } \\
\text { por mais seis meses. Comprei um barraco e vai me fazer }\end{array}$ \\
\hline
\end{tabular}




\begin{tabular}{|c|c|}
\hline Idéias Centrais & Expressões-Chave e respectivas fontes \\
\hline & $\begin{array}{l}\left.\text { muita falta para eu viver. "(Carta } n^{\circ} 80\right) \\
\text { "Eu não tenho ajuda de ninguém, só ajuda de deus e } \\
\text { deste serviço, não sou aposentada. Eu fiquei muito feliz } \\
\text { pelo sr ter aberto este serviço. Mas só que é uma pena } \\
\text { que ele está acabando daqui a dois meses. Depois que } \\
\text { acabar este serviço vou ficar no meio do mundo, não } \\
\text { poderei pagar o meu aluguel estarei sem saída."(Carta } \\
\left.n^{\circ} 135\right)\end{array}$ \\
\hline $\begin{array}{l}\text { Medo de retornar } \\
\text { à situação } \\
\text { anterior }\end{array}$ & $\begin{array}{l}\text { "Senhor quando terminar a frente, eu já choro todos os } \\
\text { dias porque não sei o que vou fazer, eu sou uma pessoa } \\
\text { sozinha com a minha filha de doze anos e eu agradeço a } \\
\text { deus a todos os dias por ter me dado este emprego, } \\
\text { faltam só três meses para eu ficar sem salários (nem } \\
\text { cesta)" (Carta n'141) } \\
\text { "(...) O meu contrato está chegando ao fim. Não sei o que } \\
\text { vou fazer para arrumar um outro emprego porque não } \\
\text { tenho estudo o suficiente e ainda sou um ex-detenta (...) } \\
\text { Só não quero virar mendiga." (Carta }{ }^{\circ} 323 \text { ) }\end{array}$ \\
\hline $\begin{array}{l}\text { Apesar de ter } \\
\text { aprendido coisas } \\
\text { novas }\end{array}$ & $\begin{array}{l}\text { "Eu adquiri meu certificado do curso de jardinagem e } \\
\text { preenchi várias fichas em agências de emprego, mas está } \\
\text { muito difícil de conseguir um novo trabalho. Preciso } \\
\text { cuidar de meus filhos, pois eles também ficam tristes } \\
\text { quando me vêem triste e eu quero ver os meus filhos } \\
\text { sempre sorrindo é felizes. "(Carta n¹46) } \\
\text { " Me formei no curso de embalagens e caixas para }\end{array}$ \\
\hline
\end{tabular}




\begin{tabular}{|l|l|}
\hline Idéias Centrais & Expressões-Chave e respectivas fontes \\
\hline & $\begin{array}{l}\text { presentes mas ainda não consegui maiores resultados } \\
\text { pois preciso de dinheiro para investir."( Carta nº5) }\end{array}$ \\
$\begin{array}{l}\text { Senhor eu não sei o que vai acontecer quando eu voltar a } \\
\text { ficar sem emprego no término dos nove meses. Sou } \\
\text { ciente do nosso contrato, mas ele é tudo que eu tenho } \\
\text { para viver materialmente falando. (Carta n¹78) }\end{array}$ \\
\hline Como vai ser? & $\begin{array}{l}\text { "Senhor quando terminar a frente, eu já choro todos os } \\
\text { dias porque não sei o que vou fazer, eu sou uma pessoa } \\
\text { sozinha com a minha filha de doze anos e eu agradeço a } \\
\text { deus a todos os dias por ter me dado este emprego, } \\
\text { faltam só três meses para eu ficar sem salários (nem } \\
\text { cesta)" (Carta n⿳141) } \\
\text { "Como vai ser, qual é o local e qual a possibilidade de } \\
\text { emprego. Vou explicar, o meu marido faz parte dos } \\
\text { bolsistas, ele trabalha na escola com supervisor e eu não } \\
\text { gostaria de vê-lo desempregado, que este emprego } \\
\text { devolveu a ele a alegria, capacidade e coragem para } \\
\text { enfrentar a crise do desemprego como muitos." (Carta } \\
n^{\circ} 149 \text { ) } \\
\text { "Gostaria de pedir a vocês que efetivassem essas } \\
\text { pessoas no emprego, pois é tão pouco tempo e todos nós } \\
\text { ficaremos todos desempregados e voltaremos à mesma } \\
\text { situação ruim. "(Carta n³50) }\end{array}$ \\
\hline
\end{tabular}

Esse temor é corroborado pela manifestação de quem escreve depois do final do período da bolsa:

Quadro 12- Idéia central e expressões-chave sobre a situação após o desligamento do PEAD, segundo as Cartas dos frentistas 


\begin{tabular}{|c|c|}
\hline Idéias Centrais & Expressões-Chave e respectivas fontes \\
\hline $\begin{array}{l}\text { Bater de porta em } \\
\text { porta, de novo, à } \\
\text { procura de } \\
\text { emprego. }\end{array}$ & $\begin{array}{l}\text { Meu nome é (...) fiz parte deste projeto, trabalhei } 9 \\
\text { meses na Universidade (... ) - foi muito bom, fui bem } \\
\text { recebida por todos, mas infelizmente acabou o contrato.. } \\
\text { Com este emprego eu recuperei a minha dignidade. Só } \\
\text { que esta dignidade só durou } 9 \text { meses. Agora comecei a } \\
\text { bater de porta em porta, à procura de outro emprego." } \\
\left(\text { Carta } n^{\circ} 330\right)\end{array}$ \\
\hline
\end{tabular}

São nove meses de trabalho remunerado, de cesta básica, de aprendizagem, de possibilidade de fazer novas relações, e o perigo sempre presente de perder essas conquistas, num contexto que continua hostil para essa população fragilizada.

Capítulo 9 - O discurso do Governo nas cartas-resposta

Este capitulo apresenta o discurso do governo, tal como se manifesta, por meio de seus delegados, na correspondência com o frentista.

O discurso do governo no caso do PEAD não se apresenta disperso em manifestações de diferentes indivíduos como é o caso do discurso dos frentistas. Ao contrário, existe um discurso oficial, onde o sujeito coletivo é - Governo $e$ os indivíduos que assinam os documentos o representam. A comunicação direta através de correspondência com os frentistas foi delegada à Coordenação do Programa Emergencial de Auxílio Desemprego que, portanto, passou a representar o sujeito Governo na relação com os missivistas. Não houve um ato específico para essa delegação, que foi compreendida como tal no bojo das atribuições da Coordenação do PEAD. As 
cartas são assinadas pelo Sr. Ilso Tamelini. Ele produziu ou fez produzir os textos e os assinou, emprestando sua voz à instituição. Com certeza, um outro representante faria um outro discurso, ainda que o teor pudesse ser semelhante.

As cartas-resposta são padronizadas, embora contenham alguns trechos diferentes em seu corpo principal relacionados à questões específicas abordadas nas cartas dos frentistas. São padronizadas a saudação, o preâmbulo e o encerramento.

Identificamos três idéias centrais explícitas no discurso das cartasresposta e uma idéia central implícita. As idéias centrais explícitas são:

- expressar o reconhecimento do frentista, individualmente, como interlocutor:

- aproveitar a oportunidade para dar os créditos do PEAD ao governo

- responder às solicitações específicas apresentadas nas cartas, inclusive explicitando que a SERT não pode garantir ao frentista a continuidade da assistência.

A idéia-central implícita é que, ao reduzir a resposta ao risco que The é apresentado pelo frentista, à explicação de que não é possivel legalmente manter o frentista na Frente após os 9 meses, não responde nem reconhece a sua responsabilidade em relação à possibilidade de reversão da situação daquela população assistida, com retorno à zona de desfiliação. 
9. 10 reconhecimento do individuo como interlocutor

Quadro 13- Idéias centrais e expressões-chave sobre o reconhecimento do frentista como interlocutor, segundo as Cartas-resposta do Governo

\begin{tabular}{|c|c|c|}
\hline Idéias Centrais & Expressões-Chave & Fonte \\
\hline $\begin{array}{l}\text { Reconhece o indivíduo } \\
\text { como interlocutor } \\
\text { respondendo de forma } \\
\text { personalizada, com } \\
\text { saudação ao missivista } \\
\text { tratando-o pelo pré- } \\
\text { nome }\end{array}$ & $\begin{array}{l}\text { "Prezado Senhor Servino" } \\
\text { (Carta-resposta } \\
79: 20 / 3 / 2000)\end{array}$ & 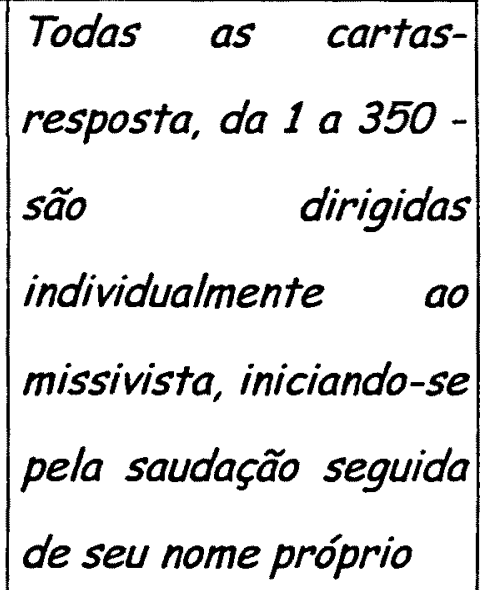 \\
\hline $\begin{array}{l}\text { Reconhece } 0 \text { individuo } \\
\text { como interlocutor } \\
\text { respondendo } \\
\text { diretamente as questões } \\
\text { apresentadas (formato } \\
\text { utilizado nas primeiras }\end{array}$ & $\mid \begin{array}{l}\text { "Em resposta à sua carta } \\
\text { de....informamos que....." }\end{array}$ & $\begin{array}{l}\text { Cartas-resposta } \\
1,2,3,4,5,6,7,8,9,10,11 \\
21,28,30,46,137,138,1 \\
39,185 \\
193,215,230,237,256 \\
262,267,271,277,289\end{array}$ \\
\hline
\end{tabular}




\begin{tabular}{|c|c|c|}
\hline Idéias Centrais & Expressões-Chave & Fonte \\
\hline $\begin{array}{l}\text { cartas-resposta } \\
\text { depois apenas } \\
\text { ocasionalmente e para } \\
\text { solicitações formuladas } \\
\text { por organizações); }\end{array}$ & & $\begin{array}{l}293,295,313 \\
326,329,338,339\end{array}$ \\
\hline
\end{tabular}




\begin{tabular}{|c|c|c|}
\hline Idéias Centrais & Expressões-Chave & Fonte \\
\hline $\begin{array}{l}\text { Reconhece o indivíduo } \\
\text { como interlocutor } \\
\text { respondendo a cartas } \\
\text { que não falam da } \\
\text { experiência } \\
\text { participação } \\
\text { Frentes, nas } \\
\text { solicitações, } \\
\text { etc.; queixas, }\end{array}$ & $\begin{array}{l}\text { "É muito importante para o } \\
\text { Governo do Estado de São } \\
\text { Paulo ter recebido a sua } \\
\text { carta, pois ela é um } \\
\text { instrumento valioso para } \\
\text { solucionarmos o problema do } \\
\text { emprego presente na vida de } \\
\text { muitos cidadãos do nosso } \\
\text { Estado" com a variação "É } \\
\text { muito importante para o } \\
\text { Governo Mário Covas...." }\end{array}$ & $\begin{array}{l}\text { Cartas-resposta: } \\
13,15,16,24,27, \\
29,31,32,33, \\
34,35,36,39,40,42,47, \\
52, \\
53,56,57.60 .63,66,69, \\
79,96, \\
116,123,150,152,167,1 \\
68, \\
181,187,192,194, \\
195,204,229, \\
230,235,243,261,265, \\
274, \\
275,302,319,320,321, \\
334, \\
337,340,342,345 .\end{array}$ \\
\hline $\begin{array}{l}\text { Reconhece o indivíduo } \\
\text { como interlocutor } \\
\text { apresentando votos de } \\
\text { sucesso }\end{array}$ & $\begin{array}{l}\text { "Esperamos que a senhora } \\
\text { tenha cada vez mais sucesso e } \\
\text { que O PEAD tenha contribuído } \\
\text { para a conquista de sua } \\
\text { cidadania e para uma vida mais } \\
\text { digna e feliz." }\end{array}$ & $\begin{array}{l}\text { Cartas-resposta } \\
138,200\end{array}$ \\
\hline
\end{tabular}




\begin{tabular}{|l|lr|l|}
\hline Idéias Centrais & Expressões-Chave & Fonte \\
\hline Reconhece o individuo & "Atenciosamente, & Ilso & Todas as cartas- \\
como interlocutor & Tamelini, Coordenador do & resposta & são \\
encerrando as cartas & PEAD" & & encerradas da mesma \\
com expressão de & & forma. \\
cortesia, assinatura, & & \\
nome e cargo do & & \\
Coordenador do PEAD & & \\
\hline
\end{tabular}

Uma parte pequena das cartas-resposta apresenta um parágrafo à guisa de palavras finais, antes do encerramento propriamente dito, reafirmando o esforço do Governo do Estado e formulando votos de sucesso ao missivista. A maioria porém apresenta apenas um encerramento cortês, com a expressão "Atenciosamente" e a assinatura original do Coordenador do PEAD, com seu nome e cargo explicitados.

9.2 A utilização da resposta para dar os créditos do PEAD

Quadro 14 - Idéias centrais e expressões-chave sobre a utilização da comunicação com o frentista para dar os créditos do PEAD, segundo as Cartas-resposta do Governo 


\begin{tabular}{|c|c|c|}
\hline Idéias Centrais & Expressões-Chave & Fonte \\
\hline $\begin{array}{ll}\text { Apresentando ou } \\
\text { reforçando } \\
\text { créditos } \\
\text { Governo } & \text { ao } \\
\text { Estado: } & \text { do } \\
\end{array}$ & & \\
\hline \begin{tabular}{|lr} 
Ressalta, & \\
inicialmente, & o \\
fato & da \\
comunicação & ter \\
sido recebida & $e$ \\
considerada & $e$, \\
em seguida, & \\
identificando & 0 \\
gestor & do \\
programa.
\end{tabular} & $\begin{array}{l}\text { "É com prazer que o Governador } \\
\text { Mário Covas recebe a sua carta } \\
\text { relatando sua participação no } \\
\text { Programa Emergencial de Auxílio- } \\
\text { Desemprego - PEAD. É importante } \\
\text { para nós que os participantes das } \\
\text { Frentes de Trabalho digam sua } \\
\text { opinião sobre o programa, pois só } \\
\text { assim o Governador juntamente com } \\
\text { o Secretário do Emprego e Relações } \\
\text { do Trabalho Walter Barelli podem } \\
\text { cada vez mais colaborar para a } \\
\text { solução do problema do desemprego } \\
\text { no Estado de São Paulo." }\end{array}$ & $\begin{array}{l}\text { Cartas-resposta } 14, \\
17, \\
18,19,20,23,25,26,32,3 \\
7,38,39,41,43,44,45,58, \\
49,50,54,55,58,59,61,6 \\
4, \\
65,67,68,70,71,72,73,7 \\
4,77,78,80,82,83,84,85 \\
\\
86,87,88,89,90,91,92,9 \\
3,94,95,97,98,99,100,1 \\
01,102,113,114,115,117,1 \\
18, \\
119,120,121,122,124,125 \\
\\
126,127,128,129,130,13 \\
1, \quad 132,133,134,135, \\
140,141,142,144,145,14 \\
6,147,148,151,153,154,1 \\
55,156,157,158,159,160 \\
161,162,163,164,165,16 \\
6,170,171,172,173,174,1 \\
75,176,177,178,179,180 \\
182,183,184,186,188,18 \\
9,190,191,197,198,200 \\
201,202,203,205,206, \\
207,208,209,210,211,21 \\
2,213,214,216,220,221,\end{array}$ \\
\hline
\end{tabular}




\begin{tabular}{|l|l|l|}
\hline Idéias Centrais & Expressões-Chave & Fonte \\
\hline & & $223,225,226,231.236$, \\
$238,239,240,241$, \\
$242,244,245,246$, \\
$248,249,252,253$, \\
$255,258,259,260$, \\
$263,264,268,269$, \\
\end{tabular}




\begin{tabular}{|c|c|c|}
\hline Idéias Centrais & Expressões-Chave & Fonte \\
\hline $\begin{array}{l}\text { Trata as Frentes } \\
\text { como mecanismo } \\
\text { de reinserção }\end{array}$ & $\begin{array}{l}\text { "Esperamos ter contribuído para } \\
\text { diminuir os índices de desemprego } \\
\text { na Região Metropolitana de são } \\
\text { Paulo, aumentar o nível de } \\
\text { qualificação e geração de renda à } \\
\text { comunidade. Indiretamente } \\
\text { buscamos a redução da violência e o } \\
\text { resgate da dignidade de } 50.000 \\
\text { cidadãos." (242) }\end{array}$ & $\begin{array}{l}\text { Cartas-resposta } \\
56,94,95,101,242\end{array}$ \\
\hline
\end{tabular}

No mês de janeiro de 2000 as cartas começavam pela resposta à questão específica apresentada pelo missivista : "Em resposta à sua carta de....informamos que.....". A partir de fevereiro de 2000, os preâmbulos foram diversificados e essa forma mais simples passou a aparecer apenas ocasionalmente ou para responder a cartas enviadas por organizações ou terceiros.

$O$ ponto de inflexão foi encontrado em fevereiro, na resposta à carta de uma missivista que pedia emprego e ajuda para negociar uma divida junto à Caixa Econômica Federal. Mereceu dois modelos, um com o preâmbulo simples e outro que passa a ressaltar que " $\dot{E}$ muito importante para 0 Governo Mário Covas ter recebido a sua carta....." A pessoa havia sido selecionada para a Frente mas ainda não fora chamada, e o motivo foi 
explicado na carta-resposta. Como ambos estão assinados, não se sabe qual deles foi de fato enviado como resposta.

Desse momento em diante passaram a ser utilizados basicamente dois tipos de preâmbulo.

Para responder à maioria das cartas (63\%) foi utilizado o preâmbulo que cita expressamente o nome do governador Mário Covas, para quem a maioria das cartas dos frentistas é endereçada, e também aproveita para informar que o governador conta com o Secretário do Emprego e Relações do Trabalho Walter Barelli para ajudar na solução do problema do desemprego no Estado de São Paulo. Então, de um lado, reitera o personagem-chave do processo de comunicação, pelo Governo, que é o próprio Covas e, de outro, informa que há mais um personagem importante em cena - o Secretário.

O segundo Preâmbulo, utilizado para $17 \%$ das cartas-resposta, afirma a importância da carta como "um instrumento valioso para solucionarmos o problema do emprego presente na vida de muitos cidadãos do nosso Estado". Identifica como interlocutor o Governo do Estado de São Paulo, ora personalizado como o Governo Mário Covas. De qualquer modo é um coletivo. Assim começam as cartas-resposta a missivistas que não são frentistas, fazem reclamações ou que pedem solução para alguma questão específica.

\subsection{As respostas às solicitações apresentadas}

Quadro 15 - Idéias centrais e expressões-chave sobre as respostas às soliciitações apresentadas pelos frentistas, segundo as Cartas-resposta do Governo 


\begin{tabular}{|c|c|c|}
\hline Idéias Centrais & Expressões-Chave & Fonte \\
\hline $\begin{array}{l}\text { Resposta } \\
\text { explicativa e de } \\
\text { orientação }\end{array}$ & $\begin{array}{l}\text { "Recomendamos que, enquanto } \\
\text { aguarda, a senhora procure o Posto } \\
\text { de Atendimento ao Trabalhador, na } \\
\text { Rua...."(319) } \\
\text { "Informamos que a frequência no } \\
\text { curso é obrigatória." (269) } \\
\text { "Quanto à sua divida junto à Caixa } \\
\text { Econômica Federal, sentimos } \\
\text { informar que a SERT não poderia } \\
\text { colaborar nesse aspecto..."(13-A) } \\
\text { "(...)o governo não tem a } \\
\text { prerrogativa de interferir no } \\
\text { parcelamento de taxas cobradas } \\
\text { pelos cartórios." (178) }\end{array}$ & $\begin{array}{l}\text { A título de exemplos. } \\
\text { Cartas resposta n's } \\
319,269,13-A, 178, \\
119 .,\end{array}$ \\
\hline $\begin{array}{l}\text { Resposta } \\
\text { explicativa e de } \\
\text { orientação }\end{array}$ & $\begin{array}{l}\text { "Para montar sua cooperativa foi-lhe } \\
\text { oferecido, durante o curso de } \\
\text { qualificação informações sobre o } \\
\text { assunto. No entanto, o senhor pode } \\
\text { procurar o Programa de Auto- } \\
\text { Emprego, sito a (...)(119) }\end{array}$ & \\
\hline
\end{tabular}




\begin{tabular}{|c|c|c|}
\hline Idéias Centrais & Expressões-Chave & Fonte \\
\hline $\begin{array}{l}\text { Resposta } \\
\text { "positiva" }\end{array}$ & $\begin{array}{l}\text { "Quanto ao curso de informática } \\
\text { solicitado, o Setor de Qualificação } \\
\text { do Programa solicita que o senhor } \\
\text { entre em contato com eles pelo } \\
\text { telefone...."(307) } \\
\text { "Informamos que a marca de café } \\
\text { Bom Gosto (...)atende às } \\
\text { especificações técnicas registradas } \\
\text { no contrato com a CBA, entretanto, } \\
\text { estaremos solicitando à CBA que o } \\
\text { produto seja substituido.(148) }\end{array}$ & $\begin{array}{l}\text { A título de exemplos: } \\
\text { Cartas resposta } n^{\circ} s \\
307,148\end{array}$ \\
\hline $\begin{array}{l}\text { Resposta } \\
\text { negativa }\end{array}$ & $\begin{array}{l}\text { "Quanto ao seu pedido para } \\
\text { permanecer nas Frentes de Trabalho } \\
\text { informamos que, de acordo com o } \\
\text { Decreto que regulamenta o PEAD, a } \\
\text { permanência dos bolsistas no } \\
\text { referido programa não pode } \\
\text { ultrapassar } 9 \text { meses." (131) } \\
\text { "(...) o Estado só pode contratar } \\
\text { funcionários através de concurso } \\
\text { público."(52) }\end{array}$ & $\begin{array}{l}\text { A título de exemplos: } \\
\text { Cartas resposta nos } \\
131 \text { e } 52\end{array}$ \\
\hline
\end{tabular}


A resposta para as questões específicas apresentadas pelos missivistas é, na maioria das vezes, objetiva e direta, quer seja positiva, negativa ou explicativa Para as numerosas cartas que pedem prorrogação do tempo na Frente é explicado que "de acordo com o Decreto que regulamenta - PEAD, a permanência dos bolsistas no referido programa não pode ultrapassar 9 meses." (131), acrescentando a explicação de que ainda há "330 mil pessoas aguardando uma convocação" (131).

Para quem não conseguiu vaga na Frente é explicado que "o esforço do nosso governador, através do Secretário Walter Barelli, em oferecer oportunidade àqueles inscritos no PEAD tem sido contínuo. Porém em virtude do número de inscritos ultrapassar a quantidade de vagas disponíveis, há pessoas que não estão participando das Frentes de Trabalho. É o caso do senhor, que se inscreveu no programa porém não foi selecionado."(116)

A outras tantas cartas cuja ambição do missivista é "ser efetivado" é explicado que "(...) o Estado só pode contratar funcionários através de concurso público."(52).

Há encaminhamentos tais como:

- "(...) quanto ao Curso de Informática solicitado, o Setor de Qualificação do Programa solicita que o senhor entre em contato com eles pelo telefone...." (307) 
- "(...) Quanto à questão do seu pagamento orientamos que traga à SERT o extrato referente ao período em que teria sido depositado um valor menor do que o de $R \$ 150,00$ (...) (304)

- "(...) a senhora pode conversar diretamente com a entidade que oferece o curso para que vocês encontrem uma solução em relação à amamentação do seu filho. Qualquer problema peça para eles nos contatarem na SERT." (269)

Para uma adolescente de 16 anos que pede emprego a Coordenação do PEAD sugere que "fique atenta a um novo programa do governo chamado" Jovem Cidadão: meu primeiro trabalho". Este programa oferece vagas de estágio em empresas para alunos regularmente matriculados no ensino médio das escolas públicas." (219)

Para um grupo que quer ajuda para comercializar produtos, a Coordenação do PEAD aconselha que "se informe, no curso de qualificação sobre a possibilidade de montarem uma cooperativa para poderem comercializar o que produzem, colocando em prática o que aprenderam no curso."(102) A outro, com a mesma questão, é dito que "para montar sua cooperativa foi-lhe oferecido durante o curso de qualificação informações sobre o assunto. No entanto, o senhor pode procurar o Programa de AutoEmprego, sito à ......"(119)

Algumas reclamações e queixas são encaminhadas ou respondidas.

- "informamos que averiguamos o seu processo de exclusão e, conforme foi apurado, junto ao seu supervisor, Márcio, não há nada que 
possamos fazer, uma vez que a decisão dos supervisores é irrevogável, salvo em casos especiais." (265)

A uma reclamação sobre a qualidade do café que vem na cesta básica é respondido que "atende às especificações técnicas registradas no contrato com a $C B A$, entretanto estaremos solicitando à $C B A$ que o produto seja substituído."(148). Para outra frentista que reclama da falta de equipamento de segurança e discriminação na Frente de Trabalho, é informado que "entramos em contato com o responsável e relatamos. $O$ mesmo ficou de apurá-las e nos dar um retorno o mais rápido possivel." (159)

Muitas questões apresentadas nas cartas dos frentistas não são do espaço de governabilidade da SERT $e$, às vezes, nem mesmo do Governo do Estado. Para elas algumas respostas são buscadas em outros órgãos: "Em relação à sua carta de 7 de fevereiro de 2000 contatamos o Centro Tecnológico de Educação Paula Souza - CEETEPS - e nos foi informado pela senhora Deise que o referido concurso oferecia dez vagas para o cargo de auxiliar de serviços sendo todas preenchidas. Sendo assim, sua classificação foi insuficiente para que você obtivesse a vaga." (23).

Outras recebem apenas algum esclarecimento: "em relação à sua contagem de anos para a obtenção de aposentadoria pedimos que a senhora procure o próprio Instituto Nacional de Seguridade Social para que eles a orientem quanto às medidas cabiveis."(248). "(...) quanto à sua dívida junto à Caixa Econômica Federal, sentimos informar que a SERT não poderia colaborar nesse aspecto, em função da CEF estar vinculada ao Governo Federal. A senhora pode procurar a própria CEF e tentar renegociar seu 
débito (13-A). "(...) o governo não tem a prerrogativa de interferir no parcelamento de taxas cobradas pelos cartórios. Sugerimos procurar a Procuradoria Geral do Estado, sita à Praça João Mendes - Sé."(78).

Quadro 16 - Idéia central e expressões-chave sobre a resposta à solicitação do frentista de continuidade da assistência, segundo as Cartas-resposta do Governo

\begin{tabular}{|c|c|c|}
\hline Idéias Centrais & Expressões-Chave & Fonte \\
\hline $\begin{array}{l}\text { O governo não } \\
\text { responde ao medo, } \\
\text { anunciado pelo } \\
\text { frentista, de } \\
\text { retornar à zona de } \\
\text { desfiliação após o } \\
\text { seu desligamento } \\
\text { da Frente de } \\
\text { Trabalho }\end{array}$ & $\begin{array}{l}\text { "(...) informamos que dentre as } \\
\text { atribuições da SERT não está a de } \\
\text { fornecer material de construção } \\
\text { para os cidadãos do Estado de São } \\
\text { Paulo (...) Assim, pedimos que a } \\
\text { senhora procure o Fundo Social de } \\
\text { Solidariedade, sito a (....)" } \\
\text { "de acordo com o Decreto que } \\
\text { regulamenta o PEAD, a permanência } \\
\text { dos bolsistas no referido programa } \\
\text { não pode ultrapassar } 9 \text { meses." } \\
\text { "Há } 330 \text { mil pessoas aguardando uma } \\
\text { convocação". }\end{array}$ & Cartas n' 267, 131 \\
\hline
\end{tabular}




\section{Capítulo 10 - Os termos do diálogo}

As pessoas falam do lugar social que ocupam, com as reservas de poder de que dispõem e com o objetivo de provocar determinadas reações no seu pretendido interlocutor. Este, por sua vez, permeia o diálogo com seu próprio poder e intenções. Nessa viagem conjunta vão sendo construídos os sentidos e os discursos, de alguma forma, se atualizam.

Nas Cartas da Frente frentista e governo são os falantes de uma interanimação dialógica que viaja de um ao outro desde os lugares sociais de onde são pronunciados.

O frentista é originário de um segmento da população que, na classificação de CASTEL (1991) estaria na zona de desafiliação ou no limiar da zona de vulnerabilidade. "parte de uma base social dispersa e volátil, ameaçada de exclusão ou mesmo já excluida do mundo da produção e dos programas assistencial-previdenciários" DOIMO (1997:130)

O frentista dirige-se diretamente ao Governador, na maioria das Cartas,_demonstrando confiança e esperança na pessoa do Governador, responsável pelo Estado, inclusive com um tratamento amistoso e íntimo. Ao mesmo tempo, demonstra o seu desconhecimento sobre a Administração Pública, quando acredita que escrevendo ao Governador poderá sensibilizar o Governo para sua situação particular. Busca o pessoal numa instituição burocrática, no sentido weberiano, cuja característica é a impessoalidade. 
Gráfico 5: Distribuição das cartas dos frentistas segundo o endereçamento

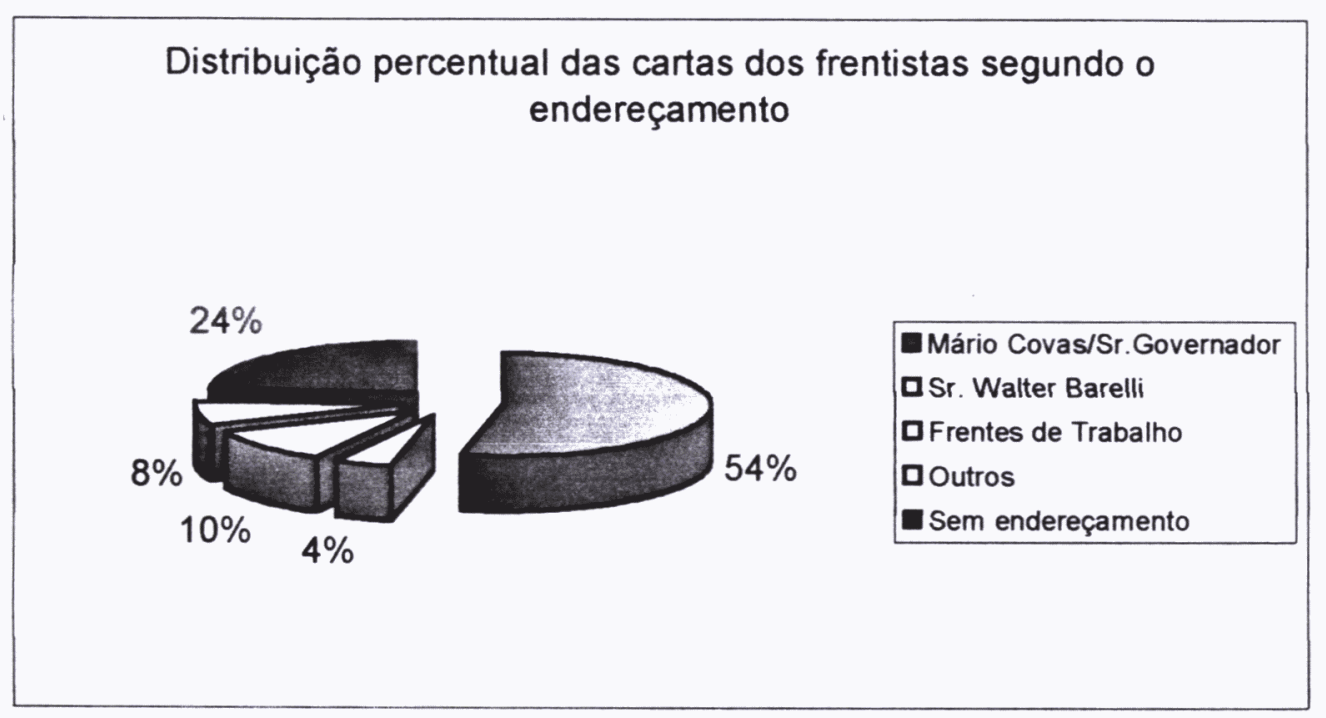

Fonte: Cartas da Frente, elaboração da autora, 2002

$\mathrm{Na}$ sua busca de comunicação com o governo, o frentista expressa e ilustra em seu discurso coletivo quatro idéias centrais:

- que vem de um grupo da sociedade imerso em uma espiral de perdas, que configura uma situação de desfiliação social, onde o desemprego desempenha função estratégica,

- que a Frente de Trabalho carreou um conjunto de ganhos materiais e imateriais que o alçou para uma zona de vulnerabilidade assistida,

- que ele tem consciência dessa vulnerabilidade e do risco de retornar à situação de desfiliação e 
- que ele agradece o que foi feito e que espera/pede que o governo, que o retirou da zona de desfiliação, não o abandone ao risco de a ela retornar.

Desenho 1: Componentes da espiral de perdas, iniciada com o desemprego e da espiral de ganhos, iniciada pela inserção na Frente de Trabalho, segundo as Cartas da Frente

\begin{tabular}{|l|}
\hline \multicolumn{1}{|c|}{ Desemprego } \\
- falta de atividade \\
remunerada \\
- inexperiência \\
- abandono, viuvez \\
- doenças
\end{tabular}

Quem responde ao frentista pelo Governo é a sua representação na área de Emprego e Relações de Trabalho, através do Coordenador do Programa Emergencial de Auxílio-Desemprego. As cartas-resposta do governo são todas personalizadas quanto ao endereçamento, com o pré-nome do destinatário, o tratamento é respeitoso e, embora sejam utilizados parágrafos-padrão, consideram questões específicas que sejam colocadas 
pelo missivista, ainda que não estejam no âmbito das atribuições da Secretaria.

As idéias centrais presentes nas cartas-resposta do governo aos frentistas são:

- demonstrar que o governo reconhece o missivista individualmente como interlocutor, através da própria resposta e do tratamento pessoal nela contida:

- aproveitar a oportunidade para identificar ou reiterar, no prólogo e no encerramento das cartas-resposta, o crédito do programa, citando o governo e a secretaria responsáveis pelo PEAD e os nomes do governador e do secretário:

- responder à questões específicas apresentadas pelos frentistas, na maior parte das vezes com orientação para encaminhamentos que não reconhece como de sua alçada (da SERT):

- explicar porque não é possível manter o frentista na Frente após os 9 meses, argumentando com a Lei e com a necessidade de atendimento de outros desempregados, ignorando o risco que the é apresentado pelo frentista do retorno dessa população à zona de desfiliação.

Desse modo, as cartas-resposta do governo ao frentista desconsideram as duas idéias principais que the são apresentadas: a 
vulnerabilidade e o risco de retornar à situação de desfiliação e a solicitação de que o governo tome medidas preventivas para evitar esse risco.

Ao contrapor à uma suposta solicitação individual - de um indivíduo que já usufruiu 9 meses de uma situação de vulnerabilidade assistida - a situação de 330 mil pessoas que aguardam uma convocação(131), o governo ignora que o frentista está dizendo, como sujeito coletivo, que a estratégia do PEAD foi boa porém não é suficiente para evitar que a população beneficiada volte para a zona de desfiliação.

O comportamento dos sujeitos com relação a um discurso é função da autoridade de seu enunciador, da legitimidade que o outro the confere (MAINGUENEAU 2000, p.18). Os frentistas, dirigindo-se ao Governador, legitimam, por antecipação, a resposta às suas missivas. E, quando recebemna, ainda que por meio de um Coordenador de Programa, sinalizam seu agradecimento por seu próprio discurso ter sido autorizado, isto é, reconhecido. Vários frentistas escrevem novamente para agradecer as respostas.

Essa interação frentista-governo além de assimétrica é complementar (MAINGUENEAU 2000), pois a diferença entre os participantes é fortemente marcada pela posição que objetivamente ocupam na sociedade $e$ como a reconhecem. Apesar de autorizar um discurso-resposta que venha a ser negativo à sua solicitação o frentista busca sensibilizar o interlocutor ainda no encerramento da sua carta, dizendo que aguarda "resposta do senhor com o coração na mão" (347) e insiste para que o interlocutor "pense nisso com carinho e atenção" (99) 
Embora as cartas-resposta possam dar alguma ilusão da existência de uma relação pessoa/pessoa, ela é de fato pessoa/instituição. O "coração na mão" pode sensibilizar a pessoa de um técnico ou dirigente da instituição mas não se mostra capaz de move-la para dar conta das grandes questões que o discurso coletivo do frentista coloca para o governo.

O contentamento do frentista ao perceber-se reconhecido como interlocutor por esse locus de poder parece superar o fato de que sua reivindicação não foi atendida. Assim, na interação de algum modo desresponsabiliza o Governo pelo risco, que percebem iminente, de resvalar novamente para a zona de desfiliação.

Tanto pelo fato de apresentar individualmente a sua reivindicação como por faze-lo pedindo a extensão de uma solução temporária, os pedidos apenas reiteram o caráter assistencialista, compensatório do Programa.

O governo, por sua vez, respondendo à situação individual por meio da contraposição da situação de um grupo muito maior ainda não assistido, retira de seus ombros a responsabilidade de solucionar o problema daquele individuo que the escreveu. Nesse momento, deixa de representar o governo e passa a falar setorialmente, como uma secretaria que, de forma isolada, não teria a condição de dar a continuidade necessária ao trabalho, iniciado pelo PEAD, de retirar um grupo da condição de desfiliação e colocá-lo temporariamente na condição de assistido. 


\section{PARTE V}

\section{REVELAÇÕES DAS CARTAS DA FRENTE}

É hora de ouvir as pessoas, diz KLIKSBERG (2001) quando empreende a sua análise das falácias e mitos do desenvolvimento social.

A questão é saber "como a História irrompe na vida de todo dia $e$ trava ai o embate a que se propõe, o de realizar no tempo miúdo da vida cotidiana as conquistas fundamentais do gênero humano, aquilo que liberta $o$ homem das múltiplas misérias que o fazem pobre de tudo: de condições adequadas de vida, de tempo para si e para os seus, de liberdade, de imaginação, de prazer no trabalho, de criatividade, de alegria e de festa, de compreensão ativa de seu lugar na construção social da realidade." (MARTINS 2000, p.12)

As pessoas se fazem ouvir através dos grupos de representação, nos aparatos legislativos, nos conselhos, nos espaços de interação entre o Estado e a Sociedade. Essa forma de escuta depende da capacidade de vocalização de interesses - que é extremamente frágil no grupo da população em estado de desfiliação.

As pessoas são ouvidas através de pesquisas, onde thes são apresentadas questões ou são estimuladas a falar sobre um tema de interesse do pesquisador. Daí resultam números, perfis estatísticos, análises sociológicas e econômicas que servem para formular ou analisar políticas públicas. 
As Cartas da Frente constituem um universo de pesquisa diferenciado, como atos de fala registrados que permitem ouvir um segmento da população cuja voz tem sido quase inaudivel para a sociedade. Essa voz vem carregada da expressão de seus desejos, suas alegrias, seus medos, desvendando como a História irrompe na vida cotidiana de sujeitos que procuram condições que lhes permitam ser atores de sua própria história (TOURAINE 1999, p.73)

Dentre as possibilidades de organização das revelações da pesquisa com as Cartas da Frente foram escolhidos dois eixos de análise:

- o frentista como sujeito da avaliação do programa e

- a consistência entre a proposta do PEAD e os resultados percebidos pelos frentistas, conforme sua informação nas Cartas.

Com a análise realizada através desses eixos busca-se apreender se 0 PEAD, como parte de uma política pública e através do provimento de meios para que a população focalizada reestabeleça seus vínculos sociais, é capaz de interromper o movimento em espiral de perdas, retirando as pessoas da zona de desfiliação ou desqualificação e apoiando sua localização em patamares mais próximos da zona de inclusão.

A escolha do primeiro eixo visa compreender, a partir do material da pesquisa, como o frentista se apresenta e como é recebido pelo governo.

O segundo eixo retoma o que é dito pelo governo e pelos frentistas acerca do PEAD como política social, já que as Cartas possibilitam ouvir o ponto de vista da população focalizada, de uma maneira qualitativa. 
Capítulo 11 - Sobre o frentista como sujeito da avaliação do PEAD

A existência do homem simples "é atravessada por mecanismos de dominação e de alienação que distorcem sua compreensão da História e do próprio destino." (MARTINS 2000, p.11), apesar da vocação do sujeito para ser ator de sua própria história, de modificar o seu meio.

O sujeito, diz TOURAINE (1999, p.73), é o desejo do individuo de ser ator, é a procura pelo próprio indivíduo das condições de ser ator de sua própria história.

O frentista coloca-se e é reconhecido como sujeito da avaliação do PEAD?

\section{1 - A apresentação individual e a vocalização do coletivo}

$O$ frentista é pinçado para o PEAD, através de um elenco de critérios definidos pelo governo, de uma população em estado de desfiliação, envolvida pela espiral de perdas que inclui a sua capacidade de vocalização.

Trata-se de uma população distanciada do protagonismo de sua história, não sabe mais o que fazer, pois não tem ninguém para o ajudar, "só Deus" (Carta $n^{\circ} 260$ ) A fome e a humilhação paralisam-na no estado de desqualificação social.

A espiral de perdas que conduz à desfiliação degrada, progressivamente, a identidade do indivíduo como cidadão. Isso é 
extremamente grave em uma sociedade em que a inscrição dos interesses nas agendas de ajuda se faz pela vocalização e num ambiente em que esse poder da voz concentra-se nos grupos identitários. Segmentos da classe média empobrecida ou da pobreza residual articulam-se nesses grupos identitátios, que, de algum modo, podem mantê-los nas zonas de vulnerabilidade assistida. Quem vocalizava pelo outro passa a vocalizar por si próprio.

Os pobres desfiliados, cuja identidade vai se esgarçando, perdem os lugares de vocalização e se distanciam da articulação em grupo.

A zona de vulnerabilidade é ainda a ante-sala da desfiliação, que integra a experiência de vida do frentista. Embora faça parte de um grande contingente de pessoas, ele é um solitário, afastado do poder que existe entre os homens quando eles agem juntos (ARENDT, 1981). E essa base social, dispersa e fragmentada, tem imensa dificuldade de articulação, na medida em que os movimentos sociais tradicionais onde os segmentos vulneráveis encontravam condições de vocalização, como o sindicalismo, se enfraqueceram.

Inserido no PEAD, o frentista começa a recuperar a auto-estima, liames de sua rede social e, com isso, recupera a sua vontade de ser ator.

A recuperação dos laços, da rede social é um aspecto crucial no processo de transformação do observador em sujeito. As redes sociais são o âmbito por excelência da interação humana, embora, como lembra NAJMANOVICH (1994), vários séculos de concepções totalitárias e excludentes tenham fossilizado boa parte de nossas relações: "Los seres 
humanos convivimos en un universo vincular en evolución, nos relacionamos com él atravesados por la emoción, somo cocreadores del mundo en el que vivimos merced a nuestra interacción compleja con lo real." (NAJMANOVICH 1994, p.70)

As Cartas podem ser vistas como uma expressão dessa vontade de colocar-se como sujeito, com o frentista buscando, em comunicação direta com a autoridade máxima do governo estadual no mais das vezes, estabelecer uma relação que permita manter o recém conquistado ingresso na zona de vulnerabilidade assistida.

Reconhecendo e explicitando os diversos aspectos da promoção que a participação do PEAD lhe proporciona, o frentista aproveita para afirmar-se também como sujeito dessa promoção, mostrando que participa ativamente através de sua capacidade de trabalho e de cooperação social.

Porém, apresenta-se individualmente e não em grupo, para instar o governo a ajuda-lo a manter-se filiado, ainda que com uma filiação assistida. Expressando de forma individual o frentista exemplifica a dificuldade de articulação coletiva do grupo de pertença.

No discurso individual transparece a consciência de que sua apresentação individual é fraca, e o próprio frentista encarrega-se de resgatar a regra geral do PEAD, que limita a participação na Frente a nove meses, pedindo uma exceção para permanecer além do prazo previsto. É a expressão do "protagonismo oculto e mutilado dos simples" (MARTINS 2000, p.13) 
A pertença compartilhada, suposta no discurso do sujeito coletivo de que "aquilo que poderia ter falado" seu "companheiro de coletividade atualizou por ele" (LEFÈVRE e LEFÈVRE 2000, p.30), não é reconhecida pelo governo nas cartas senão para reforçar que a exceção solicitada prejudicaria a expectativa de outros desfiliados.

\section{2 - O reconhecimento do discurso}

Articular um discurso, ainda que individualmente, pode ser visto como um esforço de empoderamento, pois o discurso traduz aquilo pelo que se luta, "o poder do qual nos queremos apoderar" (FOULCAUT 2000, p.10)

Iniciado o resgate da autonomia, os frentistas recuperam também a expectativa do diálogo $e$, sentindo-se de novo cidadãos, passam a buscar estabelecer comunicação. Reconquistada a base material da condição de cidadão, vem o resgate da voz.

O discurso é construído para a ação. Através do enunciado, construido a partir do repertório do falante e sua interpretação da realidade, ele busca promover uma interação com o outro falante suposto no diálogo, ao qual ele se dirige. A eficácia da comunicação, no sentido de produzir a ação, tem relação com os recursos de poder de cada um dos interlocutores envolvidos no processo de interanimação dialógica e com o reconhecimento desse poder. É preciso que os interlocutores reconheçam-se como sujeitos. 
Os frentistas quando descrevem itens de sua espiral de ganhos salientam a reconstituição da sua rede social. Fortalecidos, começa a renascer a capacidade de falar, de esperar ser ouvido e ter resposta.

Porém, essa tradução do poder a que aspiram também é enquadrada pelas condições históricas e situacionais da produção do discurso.

As Cartas da Frente são discursos do chamado tempo curto - do tempo presente - certamente eivadas das construções sociais erigidas no tempo longo, na história de dominação de classes agudizada pelo aprofundamento da desigualdade e do enfraquecimento dos movimentos sociais que representavam os interesses da população mais vulnerável ao risco da desfiliação.

"...Em toda a sociedade a produção do discurso é ao mesmo tempo controlada, selecionada, organizada e redistribuída por certo número de procedimentos que têm por função conjurar seus poderes e perigos." (FOULCAUT 2000, p.8) São procedimentos de exclusão, pois, a sociedade não permite que se diga tudo ou qualquer coisa. FOULCAUT (2000) identifica três tipos de procedimentos de exclusão: a interdição, a rejeição e a oposição verdadeiro/falso.

No que diz respeito à interdição, é o próprio frentista que parece conformar seu espaço do que é permitido dizer ao governador ou ao governo. na medida em que desculpa-se por molestar gente tão ocupada com a sua manifestação e que implora resposta, como uma sinalização de reconhecimento. 
O governo, por sua vez, aceita a manifestação individual do frentista, mas não sinaliza a percepção da sua dimensão coletiva de avaliação do PEAD. rejeitando-a implicitamente.

Como diz MAINGUENEAU "o comportamento dos sujeitos com relação a um discurso é função da autoridade de seu enunciador, da legitimidade atribuida ao status que the é reconhecido." (2000, p.18) Um discurso é autorizado quando é tido por legítimo e a eficácia do discurso está em relação a essa autorização, à sua legitimidade.

O pensamento em si é dialógico, pois "nele habitam falantes e ouvintes, que se interanimam mutuamente e que orientam a produção de sentidos e enunciados." (SPINK 1999, p.46). Por isso não é estranho que a dominação esteja presente no discurso do frentista, que ele já escreva supondo a negativa e que se contente, por antecipação, com a atenção de uma carta-resposta. O próprio frentista já supõe, na produção de seu enunciado, o limite das negociações que é capaz de fazer com o governo.

O frentista apresenta-se rogando atenção e solução, na posição subalterna do assistido que está recebendo benesses, que não tem direitos, que se sabe pouco importante, e agradece reiteradamente a atenção de que não considera merecedor.

A potência de seu discurso ao falar das condições de desfiliação anterior à Frente, dos ganhos materiais $e$ imateriais obtidos com a participação no Programa e da explicitação da consciência de sua vulnerabilidade, é suavizada pela maneira humilde de se apresentar e pela 
autorização antecipada da possivel recusa do seu interlocutor até a tomar conhecimento de sua missiva.

A assimetria de poder transpassa todo o diálogo entre frentistas e governo através das Cartas, pois também o governo elabora seu enunciado a partir dos recursos de poder de que dispõe e que são legitimados pelo próprio frentista, trabalhando com as autorizações explícitas e implícitas no seu (deles) discurso.

O Governo responde como coletivo, embora a carta seja assinada por um representante. Informa indiretamente o frentista que o reconheceu como interlocutor. Porém só responde ao que está na superfície do discurso - o sentido direto.

Residindo o poder na habilidade de agir em conjunto, por mais cartas que enviem ao governo as manifestações individuais não configuram uma ação coletiva, não são uma expressão de poder. Assim, a disposição do Governo em responder a essas manifestações deriva, possivelmente, de um lado, de uma perspectiva democrática dos representantes do Governo, que reconhecem 0 cidadão como sujeito de direitos, entre eles o da comunicação. $E$, de outro lado, de sua vontade/necessidade de angariar aprovação de potenciais eleitores.

O governo não trabalha com as Cartas da Frente como um discurso do sujeito coletivo, portadoras de uma avaliação do PEAD, e as responde como manifestações individuais, para as quais valem as limitações da lei e da própria atuação setorial da área que coordena o programa. 
As respostas positivas do governo às solicitações dos frentistas são poucas, já que a solicitação mais freqüente é para permanecer na Frente, o que legalmente não é possivel e as demais questões quase sempre estão fora do âmbito de ação da Secretaria do Emprego e Relações do Trabalho, exigindo uma ação intersetorial não prevista.

Os planejadores de políticas trabalham com números, com agregados. Junto com as expressões afetuosas, são muitos os lembretes nas Cartas dos frentistas ao Governo de que ele está lidando com vidas, com pessoas que têm nome, história, expectativas, de modo que é possivel lembrar que "o herói deste enredo" é um homem simples, no sentido de que nos fala Martins, "fragmentado, divorciado de si mesmo e de sua obra, mas obstinado no seu propósito de mudar a vida, de fazer História, ainda que pelos tortuosos caminhos de sua alienação e de seus desencontros, os difíceis caminhos cotidianos da vida." (MARTINS 2000, p.12) , E nessa condição de "herói do enredo" é que emerge a avaliação dos frentistas sobre as Frentes de Trabalho como política pública 
Capitulo 12 - Sobre as Frentes de Trabalho como política pública

Há consistência entre a proposta do PEAD e os resultados percebidos pela população dos frentistas que se manifestaram através das Cartas?

\section{1 - A formulação da política}

Em março de 1999, quando o governo de São Paulo reuniu-se com entidades sindicais e de representação patronal, entidades sociais, representantes das universidades paulistas e de fundações e empresas públicas, dentre outras, para discutir iniciativas de geração de trabalho imediato, "destacou-se a criação de Frentes de Trabalho voltadas principalmente para serviços de limpeza, manutenção e conservação de áreas e equipamentos públicos." (SERT 2000).

Frentes de Trabalho não são emprego, mas apenas ocupação de curto prazo, remunerada. Aparentemente os segmentos convidados à reflexão jogaram nos braços do Estado uma proposta tipicamente compensatória, como se tivessem acionado, antes da instituição, o mecanismo seletivo de filtragem das contradições de que nos fala OFFE (1984), já que o enfrentamento do desemprego exigiria um conjunto de políticas de governo articuladas e decisões que atuassem no modelo econômico.

A questão do desemprego era identificada como um dos principais problemas pelo próprio governo, como se vê do quadro de levantamento dos problemas, por pastas, feito no início do governo Covas. 
Quadro 17: Principais problemas, por Secretaria, segundo levantamento realizado no início do Governo Mário Covas

\begin{tabular}{|c|c|}
\hline PASTAS & PRINCIPAIS PROBLEMAS \\
\hline Educação & $\begin{array}{l}\text { Estrutura administrativa agigantada e padrão ultrapassado de } \\
\text { gestão. }\end{array}$ \\
\hline Saúde & Insuficiência e precariedade do atendimento. \\
\hline Justiça & Extrema dificuldade de acesso, pela população, à Justiça. \\
\hline Recursos Hidricos & Insuficiência na prestação e na qualidade dos serviços. \\
\hline Habitação & Crescente déficit de moradias. \\
\hline Cultura & Elitização dos serviços prestados. \\
\hline Turismo & Baixa exploração do potencial de lazer. \\
\hline Emprego & Altas taxas de desemprego e de subemprego. \\
\hline Indústria e Comércio & $\begin{array}{l}\text { Baixos investimentos e perda da competitividade no estado de } \\
\text { São Paulo }\end{array}$ \\
\hline Transportes & Insuficiência e ineficiência do sistema. \\
\hline $\begin{array}{l}\text { Agricultura e } \\
\text { Abastecimento }\end{array}$ & Distribuição ineficiente de insumos e produtos. \\
\hline Segurança & Baixas condições de segurança para a população. \\
\hline $\begin{array}{l}\text { Familia, Bem-estar e } \\
\text { Assistência }\end{array}$ & Carências não-resolvidas e má distribuição de recursos. \\
\hline $\begin{array}{c}\text { Desenvolvimento } \\
\text { Científico e } \\
\text { Tecnológico }\end{array}$ & $\begin{array}{l}\text { Ausência de articulação entre a universidade e o setor } \\
\text { produtivo. }\end{array}$ \\
\hline
\end{tabular}

Fonte: HAHN. Neide Saraceni in Reforma do setor público em São Paulo: 1995-1998 (Tese apresentada ao Curso de Pós-graduação da FGV/EAESP - Área de Concentração: Organização e Recursos Humanos - para obtenção do título de Doutor em Administração de Empresas.) São Paulo, 1998: 103 (mimeo)

Entretanto as ações para dar respostas a esses problemas, implicavam aporte de recursos, "quer como manutenção e desenvolvimento da capacidade instalada (caso da Saúde e da Educação), quer como alavancagem de novas frentes de desenvolvimento social e econômico (caso da política de 
emprego e das parcerias em transporte e infra-estrutura). " (HAHN 1998, p.86)

As condições de desorganização financeira em que a gestão Covas encontrou o Estado de São Paulo, o Banespa sob intervenção federal e a impossibilidade de captação de recursos no mercado interno de títulos porque já havia sido atingido limites críticos de endividamento, teriam motivado o Governo a decidir por concentrar esforços para o chamado ajuste fiscal - contenção de gasto público e aprimoramento da arrecadação. Esse ajuste não fora, diz HAHN (1998, p.90), discutido como parte do programa de governo e tampouco participara, como concepção, do processo de planejamento estratégico que orientou as reuniões técnicas realizadas durante o período de transição entre a vitória eleitoral e a posse do novo governo.

O governo teve êxito no ajuste fiscal. O déficit orçamentário era de $21,7 \%$ em 1994 e foi reduzido para 3,0\% em 1995 e caiu para zero no ano seguinte. Porém consumiu as energias do governo e obstaculizou 0 desenvolvimento do programa de governo.

A taxa de desemprego cresceu de 15,1 em 1996 para 19,3 em 1999. segundo a Pesquisa de Emprego e Desemprego do SEADE-DIEESE.

O crescimento do desemprego revela que as políticas públicas desenvolvidas nesse período não lograram reduzir nem mesmo manter no mesmo patamar o desemprego em São Paulo, pressionado pela tendência geral de crescimento do desemprego no País, como, de resto, em boa parte do mundo, embora em graus diferenciados, conforme a posição dos Estados 
nacionais nos blocos econômicos e a capacidade de intervenção interna dos respectivos governos.

Em junho de 1999, já no segundo mandato do governo Covas, a proposta das Frentes de Trabalho se definiu como o Programa Emergencial de Auxílio Desemprego ${ }^{24}$, focalizando uma parcela específica da população da Região Metropolitana de São Paulo, um recorte da população desempregada.

Chegando tardiamente e configurando-se como programa emergencial e de "auxílio desemprego" O PEAD parecia estar devidamente caracterizado apenas como uma política compensatória, focalizando uma parcela específica da população da Região Metropolitana de São Paulo, um recorte da população desempregada.

Esse recorte focalizou um subgrupo que estaria no limiar da condição de desqualificação social, na classificação de PAUGAM (1999), pelo acumulo de perdas - de emprego, de condições de moradia, de saúde, da rede social. São mulheres, chefes de família, desempregadas há mais tempo e com maior idade.

A Lei de criação do PEAD (Lei 10.321, de 8 de junho de 1999) restringe a até " 50.000 (cinquenta mil) trabalhadores de todas as idades, inclusive os jovens de 18 (dezoito) a 25 (vinte e cinco) anos, integrantes de parte da população desempregada residente no Estado." Porém, a Lei 10.618. de 19 de julho de 2000 deu nova redação ao artigo $1^{\circ}$, retirando o limite

\footnotetext{
${ }^{24}$ Lei 10.321, de 8 de junho de 1999, regulamentada pelo Decreto $n^{\circ} 44.034$ de 8 de junho de 1999.
} 
quantitativo da população a ser beneficiada e retirando, também, a inclusão necessária de jovens de 18 a 25 anos.

O limite foi retirado por que essa meta havia sido alcançada no primeiro ano de vigência da lei e impedia sua expansão e o segundo porque contraditório com o perfil da população focalizada estabelecido no Decreto de regulamentação (Decreto $n^{\circ} 44.034$, de 8 de junho de 1999).

Aí se nota alguma divergência entre o acordo entre o Executivo e o Legislativo, expresso na Lei, e a arquitetura desenhada pelo Executivo para - Programa. No Decreto que regulamentou a Lei já havia definido o perfil da população focalizada - pessoas desempregadas, com maiores encargos familiares; mulheres arrimo de família: com maior tempo de desemprego $e$ maior idade - quando definiu os critérios para a seleção. Esses critérios foram rigorosamente seguidos, como se pode observar no capitulo que trata do perfil da população de frentistas. À população mais jovem o governo destinou um outro Programa, que é o Primeiro Trabalho.

Além disso, a legislação do PEAD previu, explicitamente, a inclusão no Programa de pessoas portadoras de deficiência ( $3 \%$ do total de postos) $e$ egressas do sistema penitenciário do Estado ( $2 \%$ do total de postos), meta superada no primeiro ano de implantação, com 3,2 e 2,4 respectivamente. Vários dos protagonistas das Cartas da Frente revelam fazer parte desse grupo, duplamente vulnerável.

Garantir condições básicas de sobrevivência em caráter temporário e através do Estado significa, a rigor, colocar essa população focalizada na 
fase que PAUGAM (1999) denomina "de dependência" ou, segundo CASTEL (1991), na "zona de assistência". 
Desenho 2: Ilustração sobre a relação entre a espiral de perdas e ganhos $e$ as zonas que caracterizam o gradiente entre a situação de integração e a situação de desfiliação social

ESPIRAL DE PERDAS E GANHOS

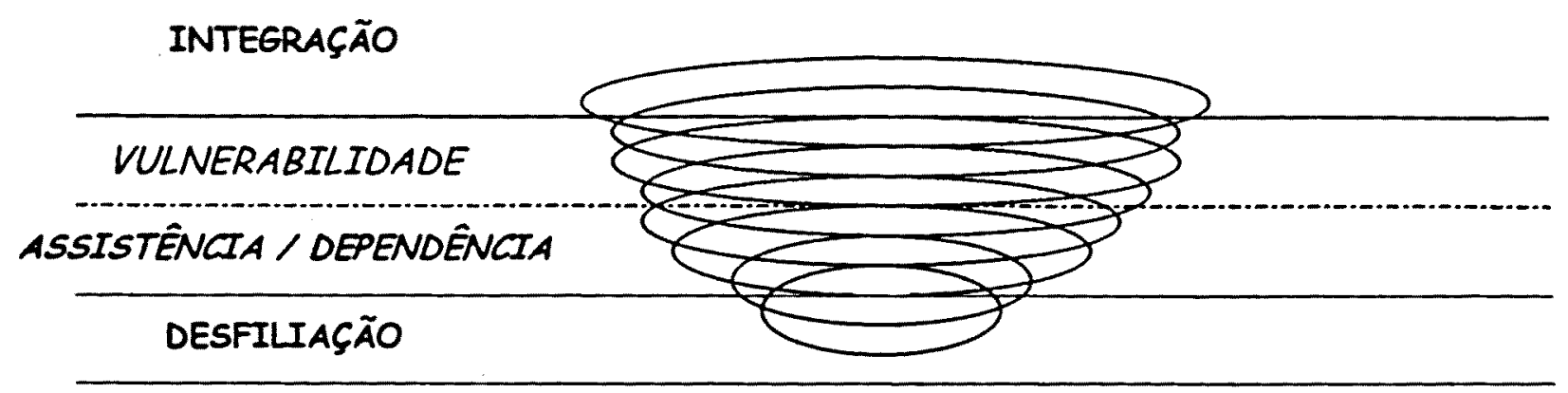

Entendo que essa chamada zona de assistência ou dependência é na verdade parte da zona de vulnerabilidade. Uma vulnerabilidade assistida.

$\mathrm{Na}$ implementação do PEAD pela Secretaria do Emprego e das Relações de Trabalho (SERT) as Frentes não se reduziram à garantia temporária (seis meses) de trabalho remunerado. Isso fica melhor colocado na segunda Lei, que modifica a redação da primeira, quando diz que o PEAD visa a "proporcionar ocupação, qualificação profissional e renda para os trabalhadores integrantes da população desempregada residente no Estado." Assim o PEAD passou a assentar-se sobre um tripé: 


\section{Desenho 3: Ilustrativo do tripé em que se assenta a estratégia de implementação do PEAD}

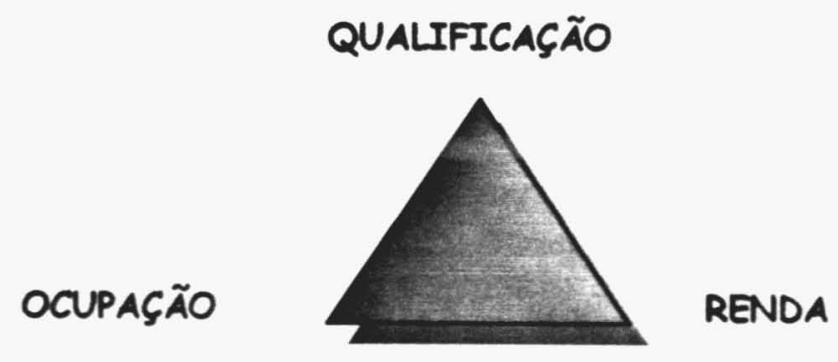

Nos seus documentos a SERT explicita que essa estratégia visa a tornar as Frentes "absolutamente diferentes $e$ inovadoras quanto associadas à qualificação e à formação profissional" 25 e orientadas por objetivos mais amplos do que os que aparecem na lei, de modo à :

- " provocar uma ruptura na cadeia formada pelo desemprego, fome, violência e caos, que aparecem na esteira de cada homem ou mulher chefes de família desempregados por mais de um ano, pode ser um bom começo para reverter a direção dessa roda" ${ }^{26}$

- "substituir a falta de auto-estima surgida devido à ausência de ocupação e renda por uma postura de enfrentamento mais enérgico e de resultados mais eficazes." 27

\footnotetext{
${ }^{25}$ São Paulo na Frente pelo Trabalho: transformando crise em crescimento. Governo do Estado, SERT, julho de 2000, s/p

${ }^{26}$ Programa de Qualificação Profissional nas Frentes de Trabalho Documento-Base, SERT, junho de 1999, p. 6

${ }^{27}$ Programa de Qualificação Profissional nas Frentes de Trabalho Documento-Base, SERT, junho de 1999, p. 6
} 
- "fazer das Frentes instrumento efetivo para reinserir o trabalhador no mercado de trabalho"28 :

\section{2 - A avaliação dos frentistas}

As Cartas possibilitam ouvir o ponto de vista da população focalizada, de uma maneira qualitativa.

O discurso do frentista captado nas Cartas tem intenções variadas, os sujeitos não foram instados a dizer como viam o PEAD e o que ele transformou em suas vidas. Mas seu discurso revela, de maneira espontânea, o que esse programa social fez com suas vidas, o que não fez e, até mesmo, o que poderia fazer.

Que indicações encontramos nas Cartas sobre as três perguntas que decorrem dos objetivos ampliados do PEAD:

a. A condição de frentista provocou uma ruptura na cadeia formada pelo desemprego, fome, violência e caos na vida do frentista?

b. Ocorreu um resgate da auto-estima e uma postura de enfrentamento mais enérgico e de resultados mais eficazes?

c. A participação nas Frentes constituiu-se em um instrumento efetivo para reinserir o trabalhador no mercado de trabalho?

${ }^{28}$ Uma construção em pleno vôo , op cit 
a) A condição de frentista provocou uma ruptura na cadeia de perdas do frentista?

Desconsiderando a formatação original da frase - um tanto exagerada - a pesquisa demonstra que, na avaliação frentista através das Cartas, houve, sim, uma ruptura na espiral de perdas e o início da inversão da roda.

As muitas indicações contidas nas Cartas, detidamente decupadas na Parte III, são expressas no discurso do sujeito coletivo ${ }^{29}$ como um alivio:

"Antes de vocês criarem esta frente de trabalho, eu estava desempregada $e$ quando vocês a criaram, ela foi a solução dos meus problemas, agora posso comprar o que eu preciso, não tudo, mas o importante.(91)

"Fiquei muito feliz quando vi meu nome na lista dos selecionados. Sou arrimo de familia, tenho 5 filhos e sou separada. Vivo da ajuda de familiares, mas agora que trabalho pela frente aliviou um pouco a barra. (37)

"Estou muito contente porque antes eu e meus filhos passávamos muita necessidade, mas depois que comecei a trabalhar na frente nunca mais faltou comida e nem material escolar para os meus filhos."(64)

O recorte da população desempregada pelo PEAD já focalizou um subgrupo que, pelo acumulo de perdas - de emprego, de condições de moradia, de saúde, da rede social - estaria desfiliada ou no limiar da zona de desqualificação social. São mulheres, chefes de família, desempregadas há mais tempo e com maior idade. 
A rigor, o programa estaria "segurando" ou inserindo essas pessoas na zona de vulnerabilidade assistida ou de dependência, Vulnerabilidade pois perduram condições de perdas graves:

"Sou arrimo de familia, tenho 5 filhos e sou separada. (...) Há dez anos que enfrento os obstáculos da vida, pois o meu marido se encontra em uma cadeira de rodas devido a um tiro que levou na coluna. Portanto ele não pode dar pensão alimentícia para as crianças."(37)

"Na minha casa eu não tenho nem uma cama para dormir. Eu durmo no colchão no chão, moro no barraco que nem cimento tem no chão."(241)

b) Ocorreu um resgate da auto-estima e uma postura de enfrentamento mais enérgico e de resultados mais eficazes?

$O$ resgate da auto-estima talvez tenha sido o ganho mais forte $e$ evidente da estratégia do tripé, utilizada pela SERT no PEAD.

Uma dimensão importante do processo inclusão/exclusão é a possibilidade de partilhar da sociedade. A exclusão do mundo do trabalho dialoga ativamente com a perda de outros laços da rede social de cada pessoa - família, amizades, relações comunitárias.

A perda dos vínculos explica processos de desintegração, de mal-estar e de adoecer, de transtornos da identidade e de perturbação dos processos de adaptação construtiva e de mudança (SLUZKI 1996, p.37).

\footnotetext{
${ }^{29}$ As frases utilizadas neste Capitulo são as do Discurso do Sujeito Coletivo apresentado na Introdução
} 
"(...) O senhor nunca me viu, não sabe quem sou eu, mas deu uma coisa que eu acho que todo o ser humano quer - dignidade e cidadania. Sabe porque eu digo tudo sito? Porque eu já senti o que é chegar ao fundo do poço. Năo ter esperança no amanhã, sentir-se um joão ninguém., Uma pessoa a mais na multidão dos excluídos." (324) "Atualmente me sinto um ser útil à sociedade." (76)

A expulsão do mundo do trabalho é uma dimensão crítica dessa ruptura, pois gera perda de autonomia, da possibilidade de auto-provimento de condições básicas de vida e promove o rompimento de outros laços da rede social de cada pessoa - família, amizades, relações comunitárias ampliando as vulnerabilidades de cada indivíduo e do grupo social.

O desemprego foi longamente relacionado à preguiça, resquício de outros momentos históricos onde a pobreza era residual, onde apenas aos inválidos ou temporariamente inaptos era admitido o não trabalho e onde a estrutura familiar dava conta de parte importante da proteção social. Desse modo, os indivíduos expulsos do mundo do trabalho ou que nele não conseguem inserção tendem a incorporar essa situação como um fracasso pessoal, "como se fosses acometidos pela peste" (PAUGAM 1999, p.73) A vítima, nesse caso, tende a se culpabilizar.

Estudo de SOLOW (1995) realça o alto custo social de períodos muito extensos de desemprego, indicando os efeitos negativos que a experiência do desemprego prolongado causa na personalidade, como apatia, 
enfraquecimento grave do interesse em socializar-se e o afastamento gradual da força de trabalho - perda da auto-estima.

A desestruturação familiar é um ponto muito importante desse processo de perdas. Vistas como uma unidade de renda e consumo (FUKUI 1998), as familias monoparentais ou onde a taxa de dependência é alta têm maior dificuldade no provimento de suas necessidades básicas. Vistas como provedora dos referenciais para o desenvolvimento de papéis sociais, "se a experiência familiar é negada ou de alguma forma desatendida, em função das condições concretas de vida e dos seus perfis, em função também dos processos de saúde e doença a que ela está submetida, o indivíduo estará mais predisposto a estados de confusão intrapsíquica, que podem levar ao desenvolvimento de condutas que variam numa gama muito grande entre o normal e o patológico." (CIAMPONE 1998, p.25)

KLIKSBERG (2001, p.58) lembra que " a deterioração de parâmetros socioeconômicos básicos da vida cotidiana de amplos setores da população da região (América Latina) está incidindo silenciosamente em um processo de reestruturação de numerosas famílias. Está surgindo o perfil de uma família desarticulada em aspectos importantes, instável, significativamente debilitada".

A desestruturação familiar, iniciada ou não pela expulsão do mundo do trabalho, representa uma importante perda de vínculos, vulnerabilizando dramaticamente os indivíduos no umbral da zona de desqualificação.

Por isso, PAUGAM detecta em suas pesquisas que "à desclassificação profissional soma-se uma desintegração familiar que aprofunda o sentimento 
de culpa." (PAUGAM 1999, p.74) Desse modo o resgate da possibilidade de prover os dependentes é extremamente importante para o resgate da autoestima.

"(...) mas depois que comecei a trabalhar na frente nunca mais faltou comida $e$ nem material escolar para os meus filhos."(64)

Outro poderoso motivo de elevação da auto-estima é o reatamento de outros vínculos sociais perdidos com a expulsão do mundo do trabalho. Reconhecer-se sujeito, resgatar a capacidade de produção e de relacionamento no processo conjunto de produção.

"Eu trabalho no posto da V.A., zona leste, e sinto que os meus serviços são bem vistos e bem vindos aqui. Sinto também que sou importante aqui, pois a limpeza que fazemos todos gostam.(175) "(...)gosto muito do que faço, adoro dividir a minha alegria com as minhas colegas de trabalho.(197)

O rompimento dos laços originais - das relações da terra natal, do núcleo familiar básico - precisam que outros fios sejam atados, a rede reconstituída. E o trabalho é um dos fios fortes, capaz de resgatar muitos nós da rede social, porque ele permite a reconstrução da condição de autonomia necessária para a relação entre iguais.

Ao aliar a garantia de uma renda mínima a ocupação contribuiu, na visão dos frentistas, para a reconstituição de laços sociais pessoais : 
amigos, colegas de trabalho, colegas de estudo, gente para dividir alegrias, responsabilidades, expectativas....elos da rede social que vão sendo tecidos.

Não parece pouco importante o fato das Frentes engajarem as pessoas em serviços públicos. São muitas as cartas que ressaltam um sentimento de gratificação por trabalhar em uma escola, em uma unidade de saúde, em uma delegacia. Essas instituições são loci de co-produção de serviços, onde é vívida a interação entre a população-cliente e o servidor público.

É sempre interessante refletir sobre as várias possibilidades do Estado cumprir seu papel na sociedade. As demandas para o serviço público são, em princípio, infinitas. Em função da definição de seu papel pela sociedade é que o Estado define o leque de demandas que irá atender, como irá alocar seus recursos. Quando se propõe da dar ocupação, utilizando cerca de 1.000 horas de trabalho de 50 mil pessoas, no período de nove meses, 0 Estado está reconhecendo que, de algum modo, há demandas por serviços públicos a serem atendidas. $E$, ao mesmo tempo, está disponibilizando parte do seu aparato para transferir tecnologia a um grupo da população, ainda que através de trabalho de baixa complexidade.

Mais de $75 \%$ dos postos de trabalho das Frentes estão em três Secretarias de Estado e mais da metade desse percentual está na Educação. Isso significa que quase $40 \%$ dos frentistas foi alocado em escolas estaduais, pondo-se em contato com uma instituição que muitos tinham tido pouca oportunidade de freqüentar $e$ onde conviveram com professores $e$ alunos. 
Há uma dimensão de contribuição social mais clara do que o trabalho que pode ser realizado na ausência do cliente, como em unidades de produção industrial. Também traz mais oportunidades de interação, pois de algum modo - limpando uma sala de atendimento à saúde, consertando uma carteira escolar, plantando flores no jardim de uma unidade pública, ou ajudando a recepcionar os clientes - o frentista tem a oportunidade de se sentir parte de uma equipe e reconhecido como um prestador de serviço público pelo usuário.

Nesse sentido, o engajamento de frentistas em ocupação no serviço público também pode ser observado pelo avesso: o significado para a comunidade. $O$ Zoológico, por exemplo, adaptou instalações para deficientes e passado a acolher mulheres em seu quadro funcional a partir das Frentes de Trabalho. Professores e alunos, profissionais e usuários de serviços de saúde, policiais passarem a conviver com pessoas que estão inseridas em um programa social do governo, não como meros dependentes da assistência, mas como cidadãos produzindo trabalho remunerado.

Talvez essa seja uma estratégia capaz de, em alguma medida, aproximar a sociedade de si mesma, torná-la mais densa, multiplicar os locais intermédios de composição social, reinserir os individuos em redes de solidariedade diretas, de que nos fala ROSANVALLON (1997, p.90)

Assim, a questão inicial é respondida afirmativamente em relação à sua primeira parte - as Cartas indicam que ocorreu um resgate da autoestima dos frentistas. Quanto a "uma postura de enfrentamento mais enérgico e de resultados mais eficazes" penso que trata-se de uma 
formulação imprópria, dado que sugere que a solução residiria na postura da própria população vulnerabilizada, num cenário onde "os atingidos não são apenas os pobres, mas todo o sistema produtivo." (DOWBOR 2001,19)

\section{c) As Frentes foram instrumento efetivo para reinserir o trabalhador no mercado de trabalho?}

As Cartas refutam essa possibilidade. Na visão do frentista, ainda engajado ou em vias de sair das Frentes, transparece vividamente o sentimento de insegurança com o futuro e com a possibilidade de inserção no mercado de trabalho.

Apesar de serem freqüentes nas Cartas as referências ao processo de qualificação, sugerindo a possibilidade de sua utilização em um trabalho informal remunerado, a maioria delas é escrita justamente no sentido de prorrogar a permanência nas Frentes, explicitando o medo do futuro.

\footnotetext{
"Além do mais estou fazendo curso de cabeleireira, estou adorando a oportunidade, pois não tive condições de comprar o material para fazer estes cursos pelo $C$. e agora estou fazendo o curso pela frente de trabalho $e$ sem precisar comprar o material, eles fornecem o material para que nós aprendamos. (...)(196)

"Trabalhei os nove meses (...), ganhei durante este periodo os 150,00 e a cesta básica, também estou terminando o meu curso.(...) foi ótimo, aprendemos muita coisa boa, além da profissão que escolhi, aprendemos aulas de cidadania, saúde, meio-ambiente, globalização, etc. Foi muito bom, só que tudo isso acabou, principalmente para mim que já tenho esta idade $e$ que todas as portas se fecham (...) o senhor nem sabe como tudo isso é dificil.(..) 239
} 
No bojo do processo de qualificação o PEAD deu atenção a um potente fator de exclusão no mundo moderno - o analfabetismo. Não há oportunidades no mercado de trabalho de São Paulo para trabalhadores analfabetos. Assim, decidiu que nenhum trabalhador da Frente permaneceria nessa condição e ofereceu, no tempo obrigatório de qualificação, a alfabetização. Embora se possa supor que essas pessoas jamais serão as mesmas pois obtiveram uma riqueza que não pode ser perdida, não há referências sobre isso nas Cartas analisadas

O frentista sinaliza que os ganhos, os instrumentos apreendidos possivelmente não sejam suficientes para garantir um emprego que ele procurou por dois anos e meio, em média, antes da Frente.

"Senhor eu não sei o que vai acontecer quando eu voltar a ficar sem emprego no término dos nove meses. Sou ciente do nosso contrato, mas ele é tudo que eu tenho para viver materialmente falando. (178)

"(...) Só Deus sabe o que pode acontecer com cada um de nós, pois está dificil demais conseguir empregos."(328)

De algum modo isso responde à segunda parte da questão anterior: não, o frentista não se sentiu suficientemente fortalecido.

A estratégia do tripé, na visão dos frentistas, teve sucesso no estancamento temporário da espiral de perdas e contribuiu para o resgate de sua auto-estima. 
O que o PEAD efetivamente conseguiu, enquanto política pública, foi realocar ou manter, durante o tempo de vinculação ao programa, o frentista e sua familia na zona de dependência ou de vulnerabilidade assistida.

$O$ fato das Frentes terem se situado em serviços públicos e o processo de qualificação obrigatório aparecem mais como ganhos de relação, do que de perspectiva de reinserção ou de permanência na zona de vulnerabilidade assistida.

Perdurando as condições de desemprego estrutural, a experiência no serviço público $e$ as horas de aprendizado no processo de qualificação não parecem suficientes para garantir o acesso ao mercado de trabalho.

Uma pesquisa com egressos seria importante para verificar a justeza do sentimento de medo do desamparo que permeia as Cartas dos frentistas.

A fragilidade tende a levar à dependência. "Como todas suas tentativas revelam-se inúteis, aceitam a idéia de serem dependentes e de manterem relações com os serviços sociais para obter uma garantia de renda e de todo tipo de auxílio." (PAUGAM 1999, p.75). O problema é que, se as pessoas saem dessa malha de proteção social, sem perspectivas, podem resvalar novamente para a marginalidade.

Não se pode acusar o PEAD de uma visão assistencialista da pobreza. A embocadura do programa está no rumo de inclusão, porém a arquitetura governamental da política social não concorre para realizar essa promessa. $O$ PEAD perde potência porque é solitário. Em princípio, deveria fazer parte de um conjunto articulado de outros projetos que se potencializassem 
mutuamente, garantindo a proteção aos segmentos inseridos na zona de vulnerabilidade assistida e provendo outros ganhos de inclusão.

A população tão cuidadosamente focalizada pelo programa não mereceu a mesma e concomitante atenção de outras áreas do governo e de sua articulação com o empresariado.

As políticas sociais devem ter como objetivo uma distribuição mais eqüitativa da riqueza, em que os mais pobres, como sujeitos, possam fazer valer seus direitos de cidadão $e$ isso "traz implícita a construção da cidadania, que deve resultar em novas relações entre Estado e sociedade" (JUNQUEIRA 2000, p.106)

Nesse sentido, vale lembrar as recomendações de KLIKSBERG (2002, p.58-67), que realça muito a necessidade de se repensar a gestão social, considerando quatro dimensões:

- o acesso efetivo das áreas sociais aos centros de poder básicos com o desenvolvimento de desenhos integrados e não apenas coordenados de política econômica e social:

- a coordenação interna da área social - educação, saúde, famila, habitação, etc-que costumam agir desvinculadamente :

- a articulação de redes que integrem organismos públicos da área social e organizações da sociedade civil e

- a participação como estratégia mestra, fator de elevação da auto-estima da comunidade e mobilizadora de potencialidades latentes e de geração de sustentabilidade 
O programa indica possibilidades da reinvenção da cidadania dos frentistas, como eles sinalizam nas Cartas, porém não dá conta, por si só, de promover $a$ inclusão e parece estar longe de representar um esforço integrado e intencional do governo - e da sociedade - nesse rumo.

No entanto são tantas as indicações dos frentistas sobre o sucesso do tripé em que se assentou o PEAD - trabalho, renda e qualificação - que essa estratégia e a participação dos "heróis do enredo" podem se potencializar na formulação de políticas públicas inclusivas, pois "as políticas sociais são decisivas para a consolidação democrática e para o futuro da economia, dado - seu potencial de redução de riscos políticos e sociais" , porém elas "só têm eficácia quando atuam de modo integrado sobre as condições de vida dos segmentos sociais" (DRAIBE 1997, p.12) 


\section{CONSIDERAÇÕES FINAIS}

No mundo contemporâneo a pobreza deixou de ser marginal ou residual. A produção da desigualdade, intrínseca ao modelo capitalista, aprofundou-se tanto na relação entre países como no âmbito dos Estados nacionais, particularmente naqueles mantidos na periferia do sistema.

Grande parcela da população mundial e nacional está imersa em uma espiral de perdas, vulnerável a um estado de desfiliação social. Essa situação é configurada em dois aspectos estratégicos: na dificuldade de inserção pelo trabalho e nas rupturas relacionais.

Na dimensão da inserção pelo trabalho, o risco não é exclusivamente o desemprego, mas também a redução de alternativas de auto-provimento que não encontram espaço no modelo de produção do capitalismo, quer do ponto de vista tecnológico, quer das relações globais determinadas por uma dinâmica financeiro transnacional.

Os programas assistenciais muitas vezes reduzem-se ao provimento dos chamados mínimos sociais. Apostam que tendo suas necessidades de sobrevivência garantidas as pessoas ganhariam autonomia suficiente para as outras conquistas. A continuidade da dependência de segmentos da população a esses programas talvez não se explique apenas pela permanência dos fatores restritivos de reinserção do mundo do trabalho, mas também por não tocar na questão da inserção relacional.

$\mathrm{Na}$ dimensão da inserção relacional a transformação da estrutura etária (aumento da longevidade e redução da natalidade) e a transformação 
da estrutura familiar, com o crescimento de famílias monoparentais e outros fatores, dialogam com as dificuldades de inserção pelo trabalho e com a pauperização, rompendo as redes relacionais e esgarçando o tecido social.

$O$ processo de desfiliação tende a degradar, progressivamente, a identidade do indivíduo como cidadão $e$, com ela, a capacidade de vocalização. Isso é extremamente grave em uma sociedade em que a inscrição dos interesses nas agendas de ajuda se faz pela vocalização e num ambiente em que esse poder da voz concentra-se nos grupos identitários.

Os desfiliados, cuja identidade vai se esgarçando, perdem os lugares de vocalização e se distanciam da articulação em grupo e, portanto, do poder que a ação conjunta pode conferir.

Desse modo, as populações suscetiveis de intervenções sociais não se inscrevem apenas na pobreza residual, mas em zonas de desfiliação ou de vulnerabilidade configuradas pela insuficiência extrema ou crescente de recursos materiais e também pelo grau de fragilização de seu tecido relacional e conseqüente aumento da marginalidade e da delinqüência.

As políticas de assistência tradicionais, em alguma medida de caráter reparador, são mais afeitas à pobreza residual, mantendo uma dependência segurada e integrada, para atender à incapacidade temporária ou definitiva de inserção autônoma pelo trabalho. Elas supõem coesão social. Assim, têm baixa potência em um cenário de dilatação da pobreza e rompimento de redes sociais.

Como parte de uma política pública e através do provimento de meios para que a população focalizada reestabeleça seus vínculos sociais, poderia o 
Programa Emergencial de Auxílio Desemprego - PEAD - ser capaz de interromper o movimento em espiral de perdas, retirando as pessoas da zona de desfiliação ou desqualificação e apoiando sua localização em patamares mais próximos da zona de inclusão?

A população de origem dos frentistas se situa na condição de extrema vulnerabilidade ou mesmo desfiliação, já na base da espiral de perdas, onde a reversão do movimento requer ação social pública, gestão social.

O governo elegeu como estratégia de atuação no Programa Emergencial de Auxilio Desemprego o tripé : trabalho, renda, qualificação. Buscando extrapolar os objetivos assistenciais explicitados nos diplomas legais, os implementadores do PEAD sonharam utilizar esse tripé não para uma relação de dependência, mas para impulsionar uma espiral de ganhos: "fazer das Frentes instrumento efetivo para reinserir o trabalhador no mercado de trabalho"30, abrir perspectivas para o futuro e somar conhecimento, "algo indispensável para competir no mundo moderno" 31 . "substituir a falta de auto-estima surgida devido à ausência de ocupação $e$ renda por uma postura de enfrentamento mais enérgico e de resultados mais eficazes" e "reverter a direção dessa roda"32.

O Governo do Estado não realizou, até agora, uma pesquisa com os egressos das Frentes de Trabalho, para verificar em que medida o PEAD restringiu-se ao seu contorno de programa assistencial e em que medida alçou o vôo pretendido.

\footnotetext{
${ }^{30}$ Uma construção em pleno vôo

31 São Paulo na Frente pelo Trabalho: transformando crise em crescimento,SERT,2000.

${ }^{32}$ Programa de Qualificação Profissional nas Frentes de Trabalho Documento-Base
} 
Mas temos a voz das Cartas da Frente. $O$ discurso dos frentistas nos diz que o tripé renda/ocupação/qualificação tem potencial transformador, porém que a reversão da direção da roda não se completou.

Ao falar dos ganhos auferidos pela sua inserção nas Frentes de Trabalho, os frentistas assinalam os itens indispensáveis como alimentos, teto, água, luz, material escolar para os filhos, mas ressaltam ainda mais outras aquisições, como o próprio exercício de atividades e o processo de aprendizagem. Estes são vistos como elementos de resgate da autonomia $e$ da rede de relações sociais.

O PEAD explicita seu caráter assistencial e o objetivo de proporcionar ocupação, qualificação profissional e renda para os trabalhadores integrantes da população desempregada residente no Estado. Porém não é um programa de assistência continuada, mas de prazo fixo - no limite, nove meses. Os documentos legais de instituição do PEAD limitam seu objetivo a essa assistência pontual e temporária. Esse fato o insere na lógica de tratamento de uma incapacidade temporária da população focalizada para reinserir-se no mercado de trabalho. Propõe-se, então, a dar esse suporte temporário, que não é apenas de um rendimento básico para o auto-provimento, mas também de fortalecimento da rede social.

Como política assistencial tradicional O PEAD pode ser criticado por trabalhar com a suposição de que seis ou nove meses de suporte ao desempregado seriam suficientes para a sua reinserção pelo trabalho $e$, mesmo, para a recuperação de sua rede social. 
As Cartas da Frente assinalam, dramaticamente, o medo do retorno à situação pré-Frente, após nove meses de trabalho remunerado, de cesta básica garantida, de algum resgate da auto-estima, de um começo de novas relações. As vulnerabilidades estão presentes e o contexto continua hostil para essa população.

O discurso dos frentistas cuida de mostrar as condições de desfiliação em que se encontra a população dos desempregados de onde são originários e vocaliza o temor de perder as conquistas do período de vinculação às Frentes que, de algum modo, os retirou dessa zona de desfiliação. Revela a consciência de que sua fragilidade diante do contexto não está vencida, e seu esforço pessoal não thes parece suficiente para sequer mantê-los na zona de vulnerabilidade assistida onde recémingressaram. $\dot{E}$ isso que o discurso dos Frentistas diz para os responsáveis pela formulação das políticas sociais.

Nessa dimensão, o governo cometeria o engano fatal de supor que no atual cenário do mundo do trabalho existissem chances de reinserção para pessoas cuja focalização, contraditoriamente, privilegiou um segmento cuja espiral de perdas os situa na zona de desfiliação ou em extrema vulnerabilidade.

Concorre para a fragilidade do PEAD sua situação de programa que, em tese, deveria estar composto com outros programas capazes de, no conjunto, compor uma política social reparadora - isto é, capaz de reduzir a zona de desfiliação ou de, ao menos, manter os vulneráveis assistidos. $E$, esta, por sua vez, precisaria fazer parte de uma política preventiva, capaz de controlar a zona de vulnerabilidade. 
Embora seja possivel identificar outros programas governamentais que poderiam compor uma política social de caráter reparador no âmbito da própria Secretaria do Emprego e das Relações de Trabalho do Governo do Estado de São Paulo, como o Banco do Povo e o Programa de Auto-Emprego, eles não estão desenhados para o mesmo segmento da população. $O$ Banco do Povo requer que seu cliente já possua um micro-empreendimento e o Programa de Auto-Emprego capta sua clientela entre as pessoas capazes de se mobilizar para um trabalho cooperativo, o que supõe uma rede social forte.

Cada programa ou projeto governamental é desenhado para um tipo de público, com características diferentes, buscando cobrir vários segmentos da população. Entretanto, se para alguns segmentos os programas constituem reforço necessário e, talvez, suficiente, para acumular ganhos, para outros, como os frentistas, precisariam integrar-se com outras iniciativas para preservar os ganhos obtidos.

Não seria possivel dar conta da situação dos frentistas somente pela ação de uma Secretaria - a SERT - e, nem mesmo, com a articulação de outras Secretarias da área social - saúde, educação, família - mas isso possivelmente já poderia melhorar os resultados.

A inversão necessária é mais profunda, pois a área social tem sido subordinada às decisões da área econômica e esta não tem os grupos mais vulneráveis como sua principal preocupação e responsabilidade na alocação dos recursos que a comunidade fornece com seus impostos.

Apesar disso, as Cartas da Frente representam um esforço de vocalização solitária que podem estar sinalizando algum fortalecimento dos 
frentistas. Sinalizam, também, que as oportunidades de resgate da autoestima e de novas relações, são capazes de contribuir para reatar liames sociais. $O$ discurso dos frentistas revela que as oportunidades de mostrar a capacidade produtiva e criativa bem como de convívio social são de fato estratégicas para a inserção relacional.

Nesse sentido, O PEAD extrapola seu caráter de programa assistencial tradicional, calcado na dependência. A estratégia das Frentes de possibilitar trabalho em serviços públicos - de saúde, educação, segurança, obras - e a focalização da qualificação em temas de cidadania e de resgate da auto-visibilidade do frentista como cidadão precisa ser considerada como um elemento de diferenciação de resultados.

Possibilitar que o desfiliado aplique ou volte a aplicar sua capacidade laborativa e se insira em um local de produção social parece potente para resgatar a auto-estima, para que a pessoa mostre a si mesma que é capaz de produzir e de criar para a sociedade e de que é capaz de tecer novos laços sociais - isso é ressaltado pelos frentistas.

O fato da ocupação acontecer em um serviço público não é de menor importância. Em primeiro lugar pela própria natureza do serviço público, onde o cidadão ganha a dimensão de estar contribuindo para a sociedade $e$ não para o enriquecimento de outra classe. Em segundo lugar, pela convivência que possibilita com segmentos da própria sociedade, no que avulta de importância o fato das Frentes serem instaladas em serviços públicos. 
É preciso prestar atenção ao relato das Cartas, para perceber a grandeza da dimensão dessa experiência no serviço público e das oportunidades de convivência e reinserção relacional que ela oferece : " sinto que também sou importante aqui", "faço meu trabalho com muito orgulho", "adquiri muita aprendizagem e amizade onde me encontro", "aprendi e pude ensinar" e "por isso eu vou cada vez melhor neste mundo que eu não conhecia." ${ }^{\text {33 }}$.

$O$ discurso do sujeito coletivo, que emergiu a partir desses fragmentos de voz, é dedicado aos formuladores de políticas públicas e aos responsáveis pela gestão social para que, a partir da avaliação desses sujeitos sociais, seja possivel aproximar os programas $e$ integrar a ação social com uma perspectiva transformadora.

$O$ desenho do PEAD inclui riquezas que devem ser consideradas, tanto na sua futura utilização como no delineamento de uma política social efetivamente reparadora, isto é, que retire segmentos da população da zona de desfiliação, da base da espiral de perdas, de modo a que políticas preventivas possam trabalhar na zona de vulnerabilidade e que se dê o passo estratégico rumo à uma divisão mais equânime da riqueza.

"Que o vazio do cenário político não nos impeça de ver que os bastidores da história estão cheios de vida, de aspirações e sobretudo de reflexão dos individuos sobre si mesmos" (TOURAINE 1999, p.352).

${ }^{33}$ Cartas $175,73,336,183,114$ 


\section{REFERÊNCIAS}

Arendt H A Condição Humana. São Paulo: EDUSP: 1981

Barros R P. Henriques R e Mendonça R Evolução recente da pobreza e da desigualdade: marcos preliminares para a política social no Brasil in Cadernos Adenauer 1: Pobreza e Política Social. São Paulo: Fundação Konrad Adenauer: 2000 , p. $11-31$

Bresser Pereira L C Reforma do Estado para a Cidadania - A Reforma Gerencial Brasileira na Perspectiva Internacional, São Paulo: Editora 34, Brasília:ENAP; 1998

Camargo CPF, Cardoso F H, Mazzucchelli F et. al São Paulo 1975

Crescimento e Pobreza Estudo realizado para a Pontifícia Comissão de Justiça e Paz da Arquidiocese de São Paulo. São Paulo:Edições Loyola; 1976 Campaña, A Em busca da definição de pautas atuais para o delineamento de estudos sobre condições de vida $e$ saúde in Barata $R$ B (org) Condições de vida e situação de saúde. Rio de Janeiro: ABRASCO; 1997, 115-165

Carvalho, M C B Gestão social: alguns apontamentos para o debate in Rico $E$ $M$ e Raichellis R (orgs) Gestão social: uma questão em debate. São Paulo:EDUC-IEE;, 1999

Castel R Da indigência à exclusão, a desafiliação precariedade do trabalho e vulnerabilidade relacional, Trad.de Â $M$ Tijiwa e revisão $L$ A Fuganti in Grupos e Coletivos, São Paulo : Ed. Hucitec, Saúde\&Loucura (4): 21-48 Extraído de Face à léxclusion: le modéle Français, Jacques Donzelot (edit) Paris: Editions Esprit-Le Seuil; 1991 
Castel R As armadilhas da exclusão in Wanderley M B. Bógus L e Yazbek M $C$ (org) Desigualdade e a questão social, $2^{a}$ ed.revista e ampliada. São Paulo:EDUC; $2000: 17-50$

Castel R As transformações da questão social in Wanderley M B. Bógus Le Yazbek MC (org) Desigualdade e a questão social, $2^{a}$ ed.revista $e$ ampliada. São Paulo:EDUC: 2000: 235-264

Ciampone M H T Uma proposta de intervenção baseada na familia in Famílias aspectos conceituais e questões metodológicas em projetos Série Discutindo a Assistência Social no Brasil, Brasília: MPAS/SAS/ São Paulo: FUNDAP: 1998: $23-30$

Costa N R Políticas Públicas, Justiça Distributiva e Inovação. Saúde e Saneamento na Agenda Social. Saúde em Debate - Série Didática.São Paulo:Hucitec; 1998

Demo P Pobreza Política Campinas: Editores Associados: 1995

Demo P Charme da Exclusão Social Campinas/SP: Autores Associados: 1998 (Coleção Polêmicas do Nosso Tempo: 61)

Doimo A M Movimentos sociais e participação política: a problemática contemporânea da ação-direta in Estudos sobre comportamento político teoria e pesquisa Lhullier L, Camino L e Sandoval $S$ (org.) Florianópolis: Letras Contemporâneas: 1997: 129-147

Dowbor L Gestão Social e Transformação da sociedade in Dowbor Le Kilsztajn S (org) Economia Social no Brasil. São Paulo: Editora SENAC: 2001: $17-41$ 
Dowbor L (coord) Benjamin A J, Alexandre I O que acontece com 0 trabalho? São Paulo:Editora SENAC: 2002 (Série Ponto Futuro, 10)

Draibe S Uma nova institucionalidade das políticas sociais in São Paulo em Perspectiva, São Paulo:Fundação Seade: 1997 v.11, n.4: 3-15

Faria WE Brasil: compatibilidade entre a estabilização e o resgate da divida social in Cadernos Adenauer 1: Pobreza e Política Social. São Paulo: Fundação Konrad Adenauer: 2000, p. 33-48

Foucault M A ordem do discurso Aula inaugural no College de France, pronunciada em 2 de dezembro de 1970. Tradução de Laura Fraga de Almeida Sampaio. São Paulo: Edições Loyola, 6a. ed; 2000 (Leituras Filosóficas 6)

Fukui L F $G$ Família: Conceitos, transformações nas últimas décadas $e$ paradigmas in Famílias aspectos conceituais e questões metodológicas em projetos Série Discutindo a Assistência Social no Brasil, Brasilia: MPAS/SAS/ São Paulo: FUNDAP; 1998, 15-22

Governo do Estado de São Paulo. Secretaria do Emprego e Relações do Trabalho. Programa de Qualificação Profissional nas Frentes de Trabalho - Documento-Base, Governo do Estado de São Paulo, SERT, junho de 1999

Governo do Estado de São Paulo. Secretaria do Emprego e Relações do Trabalho Relatório do Programa Emergencial de Auxílio Desemprego PEAD Frentes de Trabalho, SERT, setembro de 1999

Governo do Estado de São Paulo. Secretaria do Emprego e Relações do Trabalho Uma construção em pleno vôo Frentes de Trabalho 
Transformando crise em crescimento, São Paulo: Governo do Estado, SERT, Folheto tipo encarte, sem data, sem paginação.

Governo do Estado de São Paulo. Secretaria do Emprego e Relações do Trabalho São Paulo na Frente pelo Trabalho: transformando crise em crescimento. Governo do Estado, SERT, julho de 2000 / novembro 2000 Governo do Estado de São Paulo. Secretaria do Emprego e Relações do Trabalho Relatório de Pesquisa - Programa Emergencial de Auxílio Desemprego. São Paulo: FUNDAP/SERT, 2000 (mimeo)

Hahn N S Reforma do setor público em São Paulo: 1995-1998 São Paulo: 1998(Tese apresentada ao Curso de Pós-graduação da FGV/EAESP - Área de Concentração: Organização e Recursos Humanos - para obtenção do título de Doutor em Administração de Empresas.)

Jacobi P Movimentos Sociais e Políticas Públicas - demandas por saneamento básico e saúde. São Paulo 1974-84. São Paulo: Cortez: 1989

Junqueira $L A$ P Organizações sem fins lucrativos $e$ redes sociais na gestão das políticas sociais in Caderno de Administração PUC SP, n. 3 Terceiro Setor. São Paulo São Paulo: EDUC; 2000:101-125

Kliksberg B O desafio da exclusão - para uma gestão social eficiente Giselda Barroso Sauveur (coord), trad. de Marco Aurélio Nogueira (cap.1,2,4,8), Alberto Aggio (cap.7,9,10), equipe RAP (capi.3,5,6) São Paulo: Fundap; 1997

Kliksberg B Falácias e Mitos do Desenvolvimento Social. Trad.de S T Velenzuela, S C Leite. São Paulo:Cortez, Brasília(DF):UNESCO: 2001 
Kliksberg B Repensando o Estado para o desenvolvimento social: superando dogmas e convencionalismos, trad de Joaquim Ozório Pires da Silva, $2^{a}$ edição, São Paulo: Cortez; 2002 (Coleção Questões da nossa época v.64)

Lefèvre F, Lefèvre A M C e Teixeira $J \mathrm{~J} V O$ discurso do sujeito coletivo: uma nova abordagem metodológica em pesquisa qualitativa. Caixas do Sul : EDUCS: 2000

Levy P As Tecnologias da Inteligência: o futuro do pensamento na era da Informática. Rio de Janeiro: Editora 34; 1998

Maingueneau D Termos-Chave da Análise do Discurso, Tradução Márcio Venício Barbosa e Maria Emília Amarante Torres Lima, Belo Horizonte: Ed.UFMG: 2000

Martins C E $O$ circuito do poder:democracia, participação, descentralização. São Paulo:Entrelinhas; 1994

Martins J S A sociabilidade do homem simples - cotidiano e história na modernidade anômala. São Paulo:Editora Hucitec: 2000

Martins J S A sociedade vista do abismo Novos estudos sobre exclusão, pobreza e classes sociais. Petrópolis (RJ): Vozes; 2002

Menezes U B A História, cativa da memória? Para um mapeamento da memória no campo das Ciências Sociais in Revista do Instituto de Estudos Brasileiros, 34, São Paulo: USP: 1992: 9-23

Najmanovich D El lenguaje de los vínculos - de la independencia absoluta a la autonomia relativa in Dabas E e Najmanovich D (org) Redes. El lenguaje de 
los vínculos. Hacia la reconstrucción y el fortalecimiento de la sociedad civil. Buenos Aires, Barcelona, México: Paidós: 1994:33-75

NEPP - Núcleo de Estudos de Políticas Públicas da UNICAMP Brasil 1987 Relatório sobre a situação social do país. Campinas(SP): UNICAMP: 1988 Nogueira M A As possibilidades da política - idéias para a reforma democrática do Estado. São Paulo: Ed. Paz e Terra; 1998 Offe C Problemas estruturais do Estado capitalista. Rio de Janeiro: Tempo Brasileiro; 1984

Paim, Jairnilson S. e Almeida Filho, Naomar Saúde coletiva: uma "nova saúde pública" ou campo aberto a novos paradigmas? In Revista Saúde Pública, v. 32, n.4, São Paulo: USP; 1998: 299-316

Paugam 5 Enfraquecimento e a ruptura dos vínculos sociais - Uma dimensão essencial do processo de desqualificação social. Trad. Camila Giorgetti. In Sawaia B (org) As artimanhas da exclusáo - Análise psicossocial e ética da desigualdade social . São Paulo: Ed Vozes; 1999: $67-86$

Paugam S Abordagem sociológica da exclusão: $O$ conceito de desqualificação social in Véras M P B (ed.) Por uma sociologia da Exclusão Social $O$ debate com Serge Paugam. São Paulo: EDUC, 1999; 49-79

PNUD Programa das Nações Unidas para o Desenvolvimento Informe de la Comisión Latinoamericana y del Caribe sobre el Desarrollo Social [s.I.] BID: Nações Unidas: Pnud: 1995 
Prefeitura do Município de São Paulo. Secretaria do Desenvolvimento, Trabalho e Solidariedade (a) Rendimento dos chefes de domicílio no Brasil: evolução dos indicadores censitários estaduais e municipais entre 19991 e 2000, São Paulo:PMSP/SDTS; 2002

Prefeitura do Município de São Paulo. Secretaria do Desenvolvimento, Trabalho e Solidariedade (b) Desigualdade de rendimentos no estado de São Paulo: evolução dos indicadores censitários estaduais e municipais entre 1991 e 2000, São Paulo:PMSP/SDTS: 2002

Rico E M e Raichellis R (orgs) Gestão social: uma questão em debate. São Paulo:EDUC-IEE; 1999

Rocha S Alguns consensos sobre a questão da pobreza no Brasil in Dowbor $L$ e Kilsztajn S (org) Economia Social no Brasil. São Paulo: Editora SENAC; 2001: $71-88$

Rosanvallon P La representación dificil (reflexiones sobre el caso francés) in Santos, $M$ (coord): Que queda de la representación politica? Caracas:Editorial Nueva Sociedad-CLACSO; 1992 :93-105

Rosanvallon P A crise do Estado-providência. Goiânia: Editora da UFG e Editora da UnB; 1997

Sá, EN C e Ibanhes, L C O discurso (de)ambulante in Lefévre F, Lefévre $A$ $M C$ e Teixeira $J \mathrm{~J} \vee O$ discurso do sujeito coletivo: uma nova abordagem metodológica em pesquisa qualitativa. Caixas do Sul : EDUCS; 2000:123132 
São Paulo (Estado) Lei $n^{\circ} 10.321$, de 8 de junho de 1999, cria o Programa Emergencial de Auxílio-Desemprego. Diário Oficial do Estado, São Paulo, 8 jun 1999

São Paulo (Estado) Lei $n^{\circ} 10.618$, de 19 de julho de 2000, altera a Lei $n^{\circ}$ 10.321, de 8 de junho de 1999. Diário Oficial do Estado, São Paulo, 20 jul 2000

São Paulo (Estado) Decreto $n^{\circ} 44.034$, de 8 de junho de 1999, regulamenta a Lei $n^{\circ} 10.321$, de 8 de junho de 1999, Diário Oficial do Estado, São Paulo, 9 jun 1999

São Paulo (Estado) Decreto $n^{\circ}$ 44.731, de 28 de fevereiro de 2000 , prorroga por 3 (três) meses o prazo de concessão dos benefícios aos bolsistas e autoriza a SERT a celebrar contratos, convênios e outros ajustes necessário à execução do PEAD pelo prazo complementar Diário Oficial do Estado, São Paulo, 29 fev 2000

Sawaia B A legitimidade subjetiva no processo de participação social na era da globalização in Lhullier L, Camino L e Sandoval S (org.) Estudos sobre comportamento político teoria e pesquisa Florianópolis: Letras Contemporâneas; 1997: 149-159

Sawaia B (org.) As artimanhas da exclusão - análise psicossocial e ética da desigualdade social. Petrópolis:Vozes: 1999

Solow R M Mass unemployement as a social problem in Basu, Pattanaik e Suzumura Choice, Welfare and development Oxford:Clarendon Press: 1995 
Spink M J (org) Práticas discursivas e produção de sentidos no cotidiano - aproximações teóricas e metodológicas, São Paulo: Cortez:1999

Spink M J e Medrado B Produção de Sentidos no cotidiano: uma abordagem teórico-metodológica p ara a análise das práticas discursivas in Spink (org) Práticas discursivas e produção de sentidos no cotidiano - aproximações teóricas e metodológicas, São Paulo: Cortez: 1999: 41-61

Sposati A Mapa da Exclusão/Inclusão Social da Cidade de São Paulo, São Paulo:EDUC: 1996

Sluzki $C A$ rede social na prática sistêmica. São Paulo: Casa do Psicólogo:1997

Touraine A Poderemos viver juntos? Iguais e diferentes Trad de J A Clasen e E F Alves. Petrópolis (RJ): Editora Vozes; 1999

Véras M P B (edit) Por uma sociologia da exclusão social : o debate com Serge Paugam, São Paulo:EDUC; 1999

Viana $A$ L As políticas sociais $e$ as políticas de saúde no contexto do processo de globalização in Gerschmann S e Vianna M L W (org) A miragem da Pós Modernidade Democracia e políticas sociais no contexto da globalização. Rio de Janeiro: Editora FIOCRUZ; 1997:201-210

Villalobos V S O Estado de Bem-Estar na América Latina:necessidade de redefinição in Barros R P, Henriques R e Mendonça R Evolução recente da pobreza e da desigualdade: marcos preliminares para a política social no Brasil in Cadernos Adenauer 1: Pobreza e Política Social. São Paulo: Fundação Konrad Adenauer: 2000: 49-69 
Wanderley LE Desafios da sociedade civil brasileira em seu relacionamento dialético com o Estado e o mercado in Rico E M e Raichellis R (orgs) Gestão social: uma questão em debate. São Paulo:EDUC-IEE; 1999:105-127

Wanderley M B Refletindo sobre a noção de exclusão in Sawaia B (org) As artimanhas da exclusão - análise psicossocial e ética da desigualdade social. Petrópolis (RJ): Vozes; 1999: 16-26

Wanderley MB. Bógus Le Yazbek M C (org) Desigualdade e a questão social, $2^{\circ}$ ed.revista e ampliada. São Paulo:EDUC; 2000

\section{BIBLIOGRAFIA COMPLEMENTAR}

Bardin L' L'Analyse de Contenu, Paris: Presses Universitaires de France: 1977

Cardarelli $G$ e Rosenfeld M Las Participaciones de la pobreza: programas Y proyetos sociales, Buenos Aires::1998

Castel R As metamorfoses da questão social Uma crônica do salário. Trad.de I D Poleti. Petrópolis (RJ):Editora Vozes; 1998

Castro A M Sistema de proteção social no Brasil. Campinas (SP): UNICAMP/NEPP; 1991

Demo P Cidadania Tutelada e Cidadania Assistida. Campinas: Editores Associados; 1995

Doimo A M A vez e a voz do popular: movimentos e participação política no Brasil pós-70. Rio de Janeiro: Relume Dumará/ANPOCS; 1995 
Gohn, M G Teoria dos movimentos sociais: paradigmas clássicos e contemporâneos. São Paulo:Loyola; 1997

Inojosa, $R$ M Sinergia em políticas e serviços públicos: desenvolvimento social com intersetorialidade Cadernos Fundap, 22, São Paulo:FUNDAP: 2002: $102-110$

Inojosa, R M Rede de Compromisso Social: Nova Forma de Cooperação Intermunicipal in Consórcio: uma forma de cooperação intermunicipal, Informativo CEPAM ano I , $n^{\circ}$ 2, São Paulo:CEPAM; jan.2001:184-202 Inojosa, R M Saúde: esgarçamento e reconstituição da rede social, RAP Revista de Administração Pública, Rio de Janeiro: FGV, 34 (6); nov./dez. 2000: $105-116$

Inojosa, R M Construindo futuro: transetorialidade e redes de compromisso social. Cadernos de Administração da PUC - SP, número 3 (Terceiro Setor), Departamento de Administração - FEA/PUC-SP, EDUC: São Paulo: 2000: $177-190$

Inojosa, R M Tecendo Redes de Compromisso Social. Informativo NOSSAS CRIANÇAS, São Paulo: Fundação ABRINQ : setembro/outubro de 2000, $n^{\circ}$ 40, p.1

Inojosa, R M Transetorialidade e Redes de Compromisso Social, $O$ sujeito na Saúde Coletiva Anais do VI Congresso Brasileiro de Saúde Coletiva ABRASCO, Cdrom; setembro de 2000 
Inojosa, $R$ M Redes de compromisso social, RAP - Revista de Administração Pública, Rio de Janeiro:FGV, 33 (5); set./outubro 1999: 115141

Inojosa, R M Intersetorialidade e a configuração de um novo paradigma organizacional, RAP - Revista de Administração Pública, Rio de Janeiro: FGV: 32(2) mar-abr.1998:35-48

Junqueira, $L A P$ e Inojosa, $R M O$ setor saúde $e$ o desafio da intersetorialidade, Cadernos FUNDAP 21, São Paulo:Fundap: 1998: 156164

Junqueira, L A P : Inojosa, $R M$ e Komatsu, S. Descentralização e Intersetorialidade: A experiência de Fortaleza, in EI Tránsito de la cultura burocrática al modelo de la gerencia pública, UNESCO/CLAD; 1998:63124.

Paugam, Serge La desqualification social. Paris:Presses Universitaires de France, 1991

Paugam, Serge (org) L'exclusion social: l'etat de savoir. Paris : La Découverte, 1996

Schweickert R A transformação do Estado de Bem-Estar Social Europeu in Cadernos Adenauer I Pobreza e política social , São Paulo: Fundação Konrad Adenauer: 2000 